Article

\title{
Protein Targets of Frankincense: A Reverse Docking Analysis of Terpenoids from Boswellia Oleo-Gum Resins
}

\author{
Kendall G. Byler ${ }^{1}$ and William N. Setzer ${ }^{1,2, * \text { (D) }}$ \\ 1 Department of Chemistry, University of Alabama in Huntsville, Huntsville, AL 35899, USA; \\ kendall.byler@uah.edu \\ 2 Aromatic Plant Research Center, 230 N 1200 E, Suite 102, Lehi, UT 84043, USA \\ * Correspondence: wsetzer@chemistry.uah.edu; Tel.: +1-256-824-6519
}

Received: 19 July 2018; Accepted: 28 August 2018; Published: 31 August 2018

\begin{abstract}
Background: Frankincense, the oleo-gum resin of Boswellia trees, has been used in traditional medicine since ancient times. Frankincense has been used to treat wounds and skin infections, inflammatory diseases, dementia, and various other conditions. However, in many cases, the biomolecular targets for frankincense components are not well established. Methods: In this work, we have carried out a reverse docking study of Boswellia diterpenoids and triterpenoids with a library of 16034 potential druggable target proteins. Results: Boswellia diterpenoids showed selective docking to acetylcholinesterase, several bacterial target proteins, and HIV-1 reverse transcriptase. Boswellia triterpenoids targeted the cancer-relevant proteins (poly(ADP-ribose) polymerase-1, tankyrase, and folate receptor $\beta$ ), inflammation-relevant proteins (phospholipase A2, epoxide hydrolase, and fibroblast collagenase), and the diabetes target $11 \beta$-hydroxysteroid dehydrogenase. Conclusions: The preferential docking of Boswellia terpenoids is consistent with the traditional uses and the established biological activities of frankincense.
\end{abstract}

Keywords: frankincense; Boswellia; cembranoids; cneorubenoids; boswellic acids; molecular docking

\section{Introduction}

The genus Boswellia (Burseraceae) is made up of resiniferous trees and shrubs that are distributed across India, the Arabian peninsula, and Africa [1,2]. The genus is known for its aromatic terpenoid oleo-gum resin, frankincense. Frankincense has been a part of human religious ceremonies and ethnobotany for thousands of years [3]. Important frankincense-producing species include B. carteri, which grows in Somaliland and Puntland [1], B. sacra, found in Yemen, southern Oman, Somalia, and Somaliland [2], B. frereana, which is endemic to Somalia [2], B. papyrifera, primarily found in Sudan, Eritrea, and Ethiopia [4], and B. serrata, which grows primarily in India [5].

Frankincense oleo-gum resin has been used traditionally to treat wounds [6], to treat inflammatory diseases [7], for oral hygiene [8], as well as for its psychoactive effects [9,10]. The biological activities of frankincense have been attributed to its essential oils [11] and its non-volatile diterpenoids and triterpenoids [6]. Although frankincense has been used for various maladies and conditions, and numerous biological activities have been attributed to frankincense, the particular biological targets are not well established. In this work, we have carried out a reverse molecular docking study of Boswellia cembranoid diterpenoids (Figure 1), cneorubenoid diterpenoids (Figure 2), and triterpenoids (Figure 3) against a library of 16,034 potential druggable target proteins.

The cembranoids incensole and incensole acetate were detected in the oleo-gum resin of B. papyrifera, while serratol was found in B. carteri, B. sacra, and B. serrata [12]. The boscartins have been 
isolated from the oleo-gum resin of B. carteri [13]. Incensole oxide has been isolated from B. carteri and the X-ray crystal structure determined [13,14]; both incensole oxide and incensole oxide acetate have been detected in small concentrations in the essential oil from the resin of B. papyrifera [15]. Isoincensole oxide [16,17] and isoincensolol [17] were isolated from B. carteri resin. Verticilla-4(20),7,11-triene and serratol and were isolated from B. carteri [18] and B. serrata [19], respectively.<smiles>C/C1=C/CC(O)C2(C)CCC(C(C)C)(C[C@@H](O)[C@]3(C)CC[C@@H]1O3)O2</smiles>

Boscartin A<smiles>CC(C)=CC(O)C[C@]1(C)OC1C[C@@]1(C(C)C)CCC(C)([C@H](O)CC(=O)C(C)C)O1</smiles>

Boscartin E<smiles>CC1=CC[C@](CC=C(C)CC[C@@H](O)C2(C)CC[C@@](C)(C(C)C)O2)(C(C)C)OC(C)=CCC1</smiles>

Incensole<smiles>CC1=CCC2(C(C)C)CCC(C)(O2)[C@H]2CC[C@](C)(O2)[C@@H](O)CC1</smiles>

Isoincensole oxide

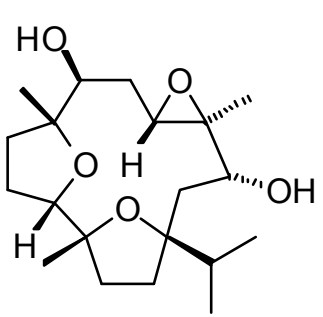

Boscartin B<smiles>CC(=O)C(=O)C[C@@H](O)C1(C)CCC(CC2O[C@@]2(C)CCC=C(C)C)(C(C)C)O1</smiles>

Boscartin F<smiles>CCC(C)=CCC1(C(C)C)CCC(C)(C(CCC(C)=CCCC(C)=O)OC(C)C)O1</smiles>

Incensole acetate

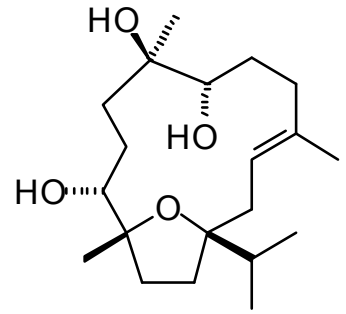

Isoincensolol<smiles></smiles>

Boscartin C<smiles>CC(=O)C(=O)CC(O)C1(C)CCC(C[C@H]2OC2(C)CCC=C(C)C)(C(C)C)O1</smiles>

Boscartin G<smiles>C=C(C)CCC(O)C1(C)CCC(C[C@@H]2O[C@H]2CCC=C(C)C)(C(C)C)O1</smiles>

Incensole oxide<smiles>C/C=C(\C)CC/C=C(\C)CC[C@](O)(CC/C=C(\C)CC/C=C(/C)CC)C(C)C</smiles>

Serratol<smiles>CC(C)C1(C[C@@H]2O[C@]2(C)CC/C=C(/C=O)CCC(O)C2(C)CCC2(C)O)CO1</smiles>

Boscartin D<smiles>CC1=CC[C@]2(C(C)C)CC[C@@H](C)O[C@H](CC[C@@](C)(O)C(O)CC1=O)O2</smiles>

Boscartin $\mathrm{H}$<smiles></smiles>

Incensole oxide acetate

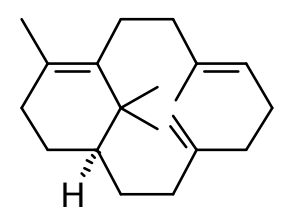

4(20), 7,11-Verticillatriene

Figure 1. Macrocyclic diterpenoids found in Boswellia species. 


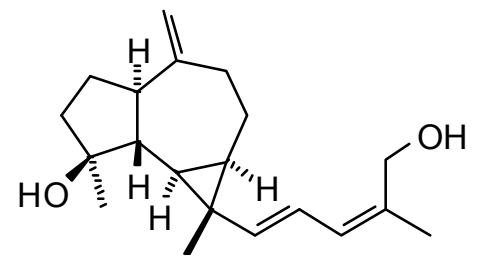

Boscartol A

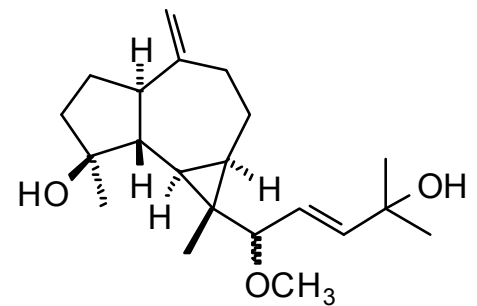

Boscartol D

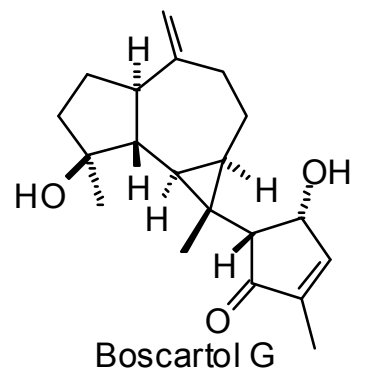<smiles>C=C1CC[C@H]2[C@@H](/C=C/C=C(C)C)C2(C)[C@@H]2[C@](C)(O)CC[C@@]12C</smiles>

Olibanumol D<smiles>C=C1CC[C@@H]2[C@H]([C@H]3[C@H]1CC[C@]3(C)O)C2(C)CC/C=C(/C)CO</smiles>

Boscartol B<smiles>C=C1CC[C@H]2[C@@H]([C@H]3[C@@H](C)CC[C@@H]32)C1(C)C[C@H](O)/C=C(/C)CO</smiles>

Boscartol E

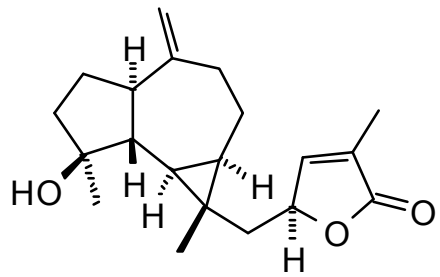

Boscartol $\mathrm{H}$

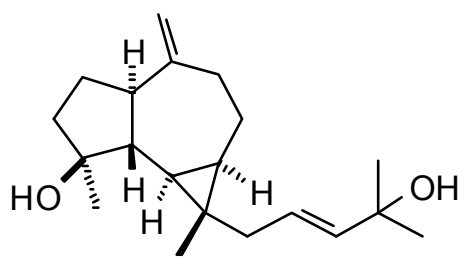

Boscartol C

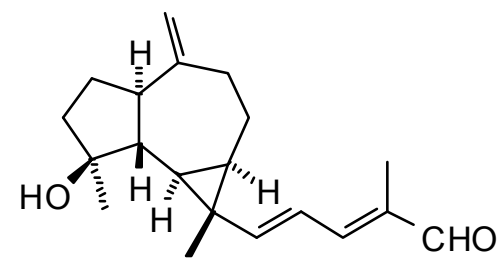

Boscartol F

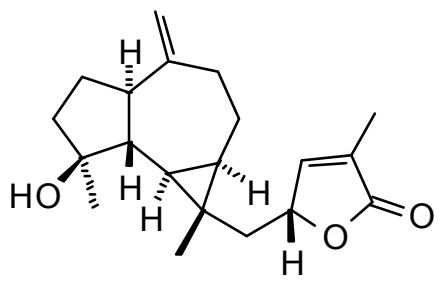

Boscartol I

Figure 2. Cneorubenoid diterpenoids isolated from Boswellia carteri.

Boswellia carteri oleo-gum resin is the source of several prenylated aromadendrane (cneorubenoid) diterpenoids (Figure 2) [20,21].

Numerous ursane, oleanane, lupane, dammarane, and tirucallane triterpenoids have been isolated and characterized from Boswellia species (Figure 3) [22]. Boswellia serrata has yielded $\alpha$-boswellic acid, $\beta$-boswellic acid, 3-acetyl- $\alpha$-boswellic acid, 3-acetyl- $\beta$-boswellic acid, 11-keto- $\beta$-boswellic acid, and 3-acetyl-11-keto- $\beta$-boswellic acid [23]. Boswellia carteri has yielded the oleanane triterpenoids $\alpha$-boswellic acid, and 3-acetyl- $\alpha$-boswellic acid; the ursane triterpenoids $\beta$-boswellic acid, 3-acetyl- $\beta$-boswellic acid, 11-keto- $\beta$-boswellic acid, 3-acetyl-11-keto- $\beta$-boswellic acid, 3-acetyl-11 $\alpha$-methoxy- $\beta$-boswellic acid, 9,11-dehydro- $\beta$-boswellic acid, and 3-acetyl-9,11-dehydro- $\beta$-boswellic acid; the lupane triterpenoids lupeolic acid and 3-acetyl lupeolic acid; and the tirucallane triterpenoids $\alpha$-elemolic acid, $\beta$-elemonic acid, $3 \alpha$-hydroxytirucalla-7,24-dien-21-oic acid, $3 \alpha$-acetoxytirucalla-7,24-dien-21-oic acid, and $3 \beta$-hydroxytirucalla-7, 24-dien-21-oic acid [24]. Olibanumols A, B, C, H, I, J' [25], E, F, G [20], K, L', M, and N [26] have been isolated from the oleo-gum resin of $B$. carteri. B. carteri resin has also yielded boscartenes $\mathrm{L}, \mathrm{M}$, and $\mathrm{N}$, as well as trametenolic acid B, 3-oxotirucalla-7,9(11),24-trien-21-oic acid, and (20S)-3,7-dioxo-tirucalla-8,24,-dien-21-oic acid [27]. 


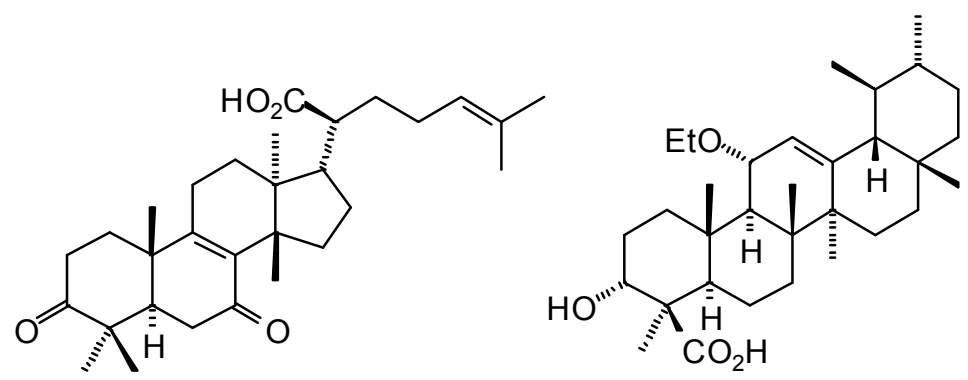

(20S)-3,7-Dioxotirucalla-8,24dien-21-oic acid

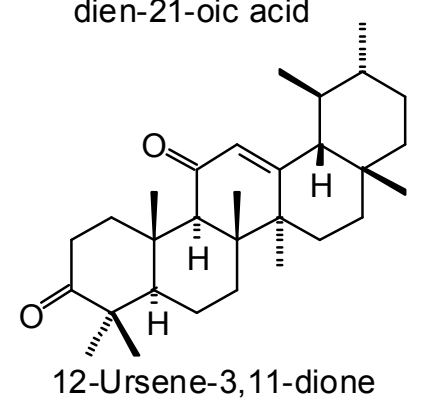

11 -Ethoxy- $\beta$-boswellic acid<smiles>CC1[C@H](C)CCC2(C)CC[C@]3(C)C(=CCC4[C@@]5(C)CC[C@@H](O)[C@@](C)(CO)C5=CC[C@]43C)C12C</smiles>
12-Ursene-3,24-diol<smiles>CC(C)=CC[C@H]1O[C@H]1[C@H]1CCC2(C)[C@@H]3CC[C@H]4C(C)(C)C(=O)CC[C@]4(C)[C@H]3CC[C@]12C</smiles>

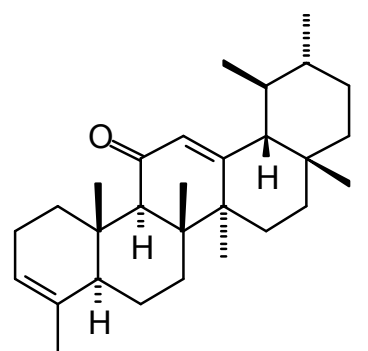

20,22-Epoxytirucall-24-en-3-one 24-Nor-3,12-ursadien-11-one<smiles>CC1=CCCC2(C)C3=CC=C4C5(C)C(C)[C@@H](C)CCC5(C)CC[C@]4(C)C3(C)CC[C@H]12</smiles>

24-Nor-3,9(11),12-ursatriene<smiles>C=C(C)[C@H]1CCC2(C)CC[C@]3(C)C(=CCC4[C@@]5(C)CC[C@H](OC(C)=O)[C@](C)(C(=O)O)C5CC[C@]43C)C12</smiles>

3-Acetoxy-12,20(29)lupadien-24-oic acid<smiles>CC1[C@H](C)CCC2(C)CC[C@]3(C)C(=CC(=O)C4[C@@]5(C)CC[C@H](O)[C@@](C)(C(=O)O)C5CC[C@]43C)C12C</smiles>

11 -Keto- $\beta$-boswellic acid<smiles>CC1[C@H](C)CCC2(C)CC[C@]3(C)C(=CCC4[C@@]5(C)C[C@H](O)[C@@H](O)[C@](C)(C(=O)O)C5CC[C@]43C)C12C(=O)O</smiles>
2,3-Dihydroxy12-ursen-24-oic acid<smiles>CC1=CCCC2(C)C3=CC=C4C5CC(C)(C)CCC5(C)CC[C@]4(C)C3CC[C@H]12</smiles>

24-Nor-3,9(11),12-oleanatriene<smiles>C=C(C)[C@H]1CCC2(C)CC[C@]3(C)C(CCC4[C@@]5(C)CC[C@H](OC(C)=O)[C@@](C)(C(=O)O)C5CC[C@]43C)C12</smiles>

3-Acetoxy-20(29)-Iupen-24-oic acid (= 3-Acetyl lupeolic acid)

Figure 3. Cont. 
<smiles>C=C(C)[C@H](O)CC[C@](C)(O)[C@H]1CC[C@]2(C)C1CCC1C3(C)CCC(OC(C)=O)C(C)(C)C3CCC12C</smiles>

$3 \beta$-Acetoxy-20 S,24dihydroxydam mar-25-ene

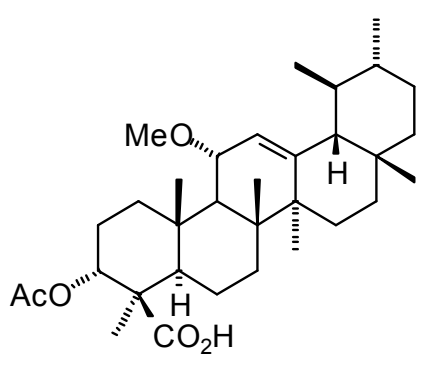

3-Acetyl-11 $\alpha$-methoxy$\beta$-boswellic acid

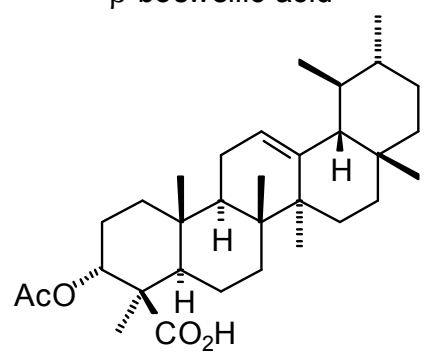

3-Acetyl- $\beta$-boswellic acid

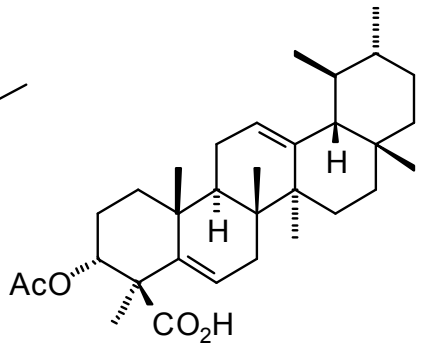

3-Acetoxy-5, 12 ursadien-24-oic acid<smiles>CC(=O)O[C@H]1CCC2(C)C3=CC=C4C5C(C)[C@@H](C)CCC5(C)CC[C@]4(C)C3CCC2[C@]1(C)C(=O)O</smiles>

3-Acetyl-9,11-dehydro$\beta$-boswellic acid

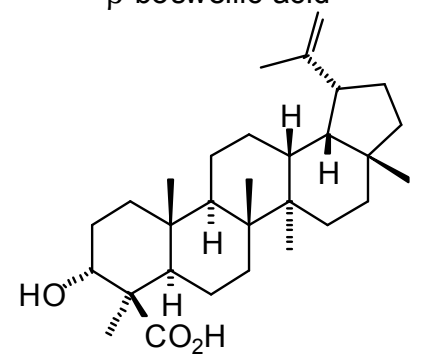

3-Hydroxy-20(29)-lupen-24-oic acid (= Lupeolic acid)

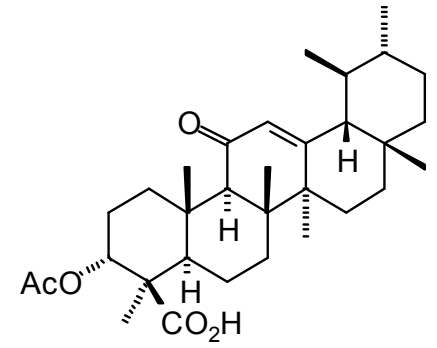

$$
\text { 3-Acetyl-11-keto- }
$$
$\beta$-boswellic acid<smiles>CC(=O)O[C@H]1CCC2(C)C3CC=C4C5CC(C)(C)CCC5(C)CC[C@]4(C)[C@H]3CC[C@]2(C)[C@H]1C(C)(C)O</smiles>

3-Acetyl- $\alpha$-boswellic acid<smiles>CC(C)=CCC[C@H](C(=O)O)[C@H]1CC[C@@]2(C)C1=CC[C@@]1(C)C2=CC[C@H]2C(C)(C)C(=O)CC[C@@]21C</smiles>

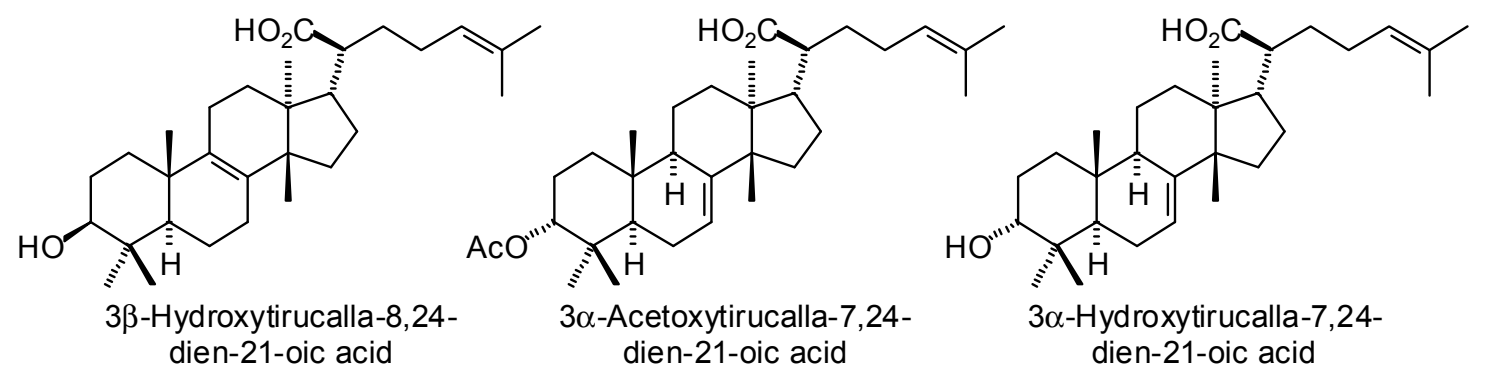

Figure 3. Cont. 


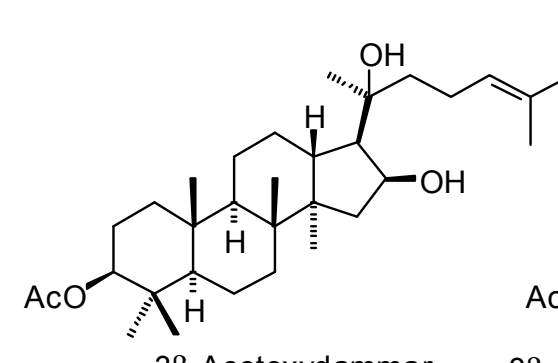

$3 \beta$-Acetoxydammar24-ene-16 $\beta, 20 R$-diol

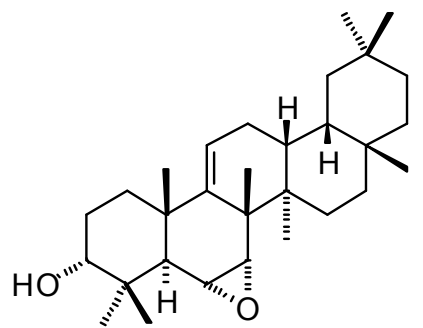

6,7-Epoxy-9(11)-oleanen-3-ol

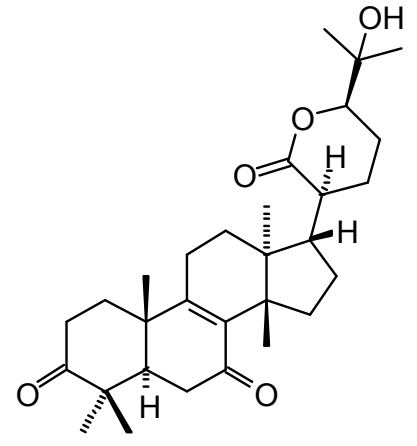

Boscartene L

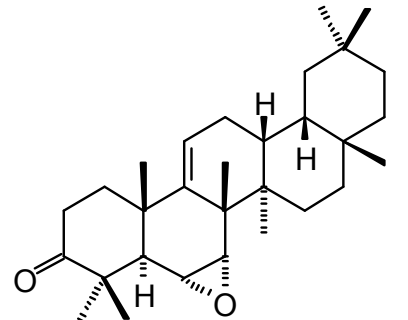

6,7-Epoxy-9(11)-oleanen-3-one<smiles>CC(C)(O)C1CC[C@H]([C@H]2CCC3(C)C4=C(C(=O)C[C@@]23C)C2(C)CCC(=O)C(C)(C)[C@H]2CC4=O)C(=O)O1</smiles>

Boscartene M

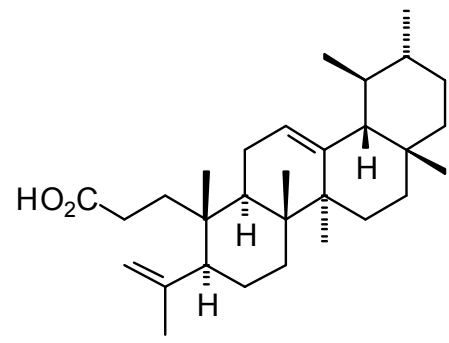

4,23-Dihydroroburic acid<smiles>CC1[C@H](C)CCC2(C)CC[C@]3(C)C(=CC=C4C5(C)CC[C@H](O)[C@](C)(C(=O)O)C5CCC43C)C12C</smiles>

9,11-Dehydro- $\beta$-boswellic acid<smiles></smiles>

Boscartene $\mathrm{N}$

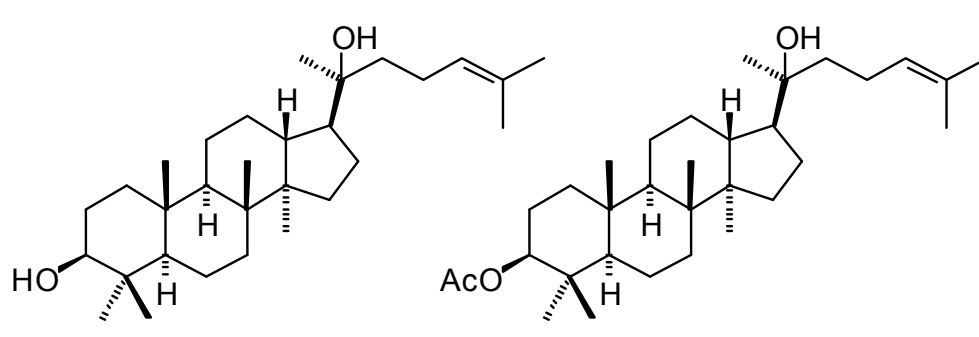

Dammarenediol II

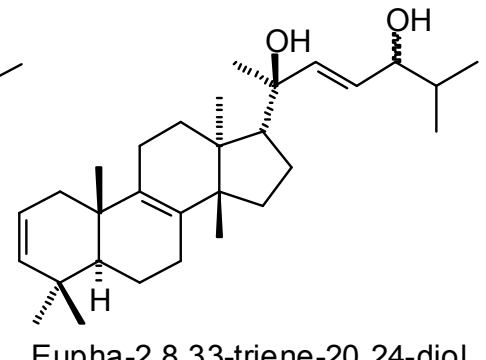

Eupha-2,8,33-triene-20,24-diol

Figure 3. Cont. 


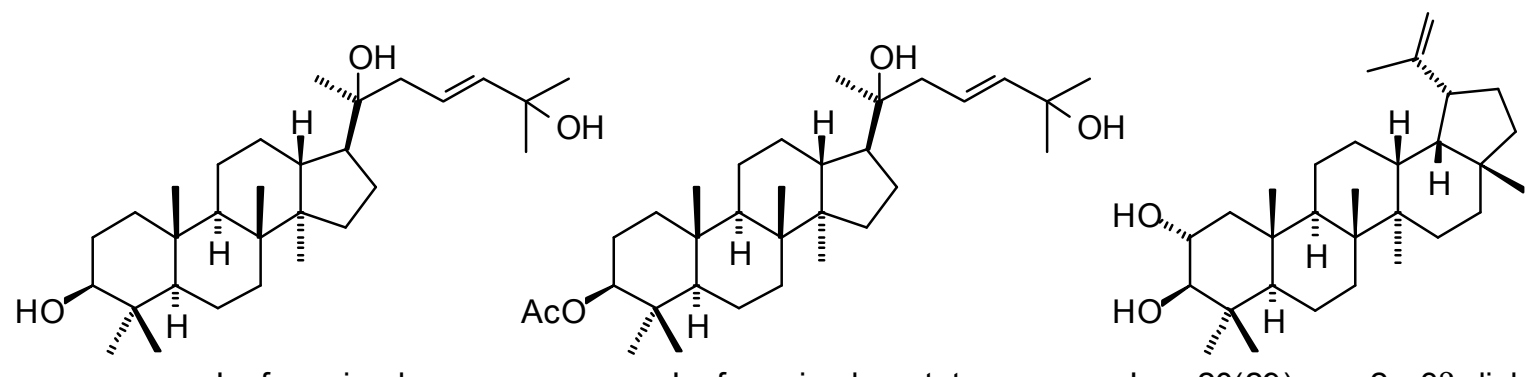

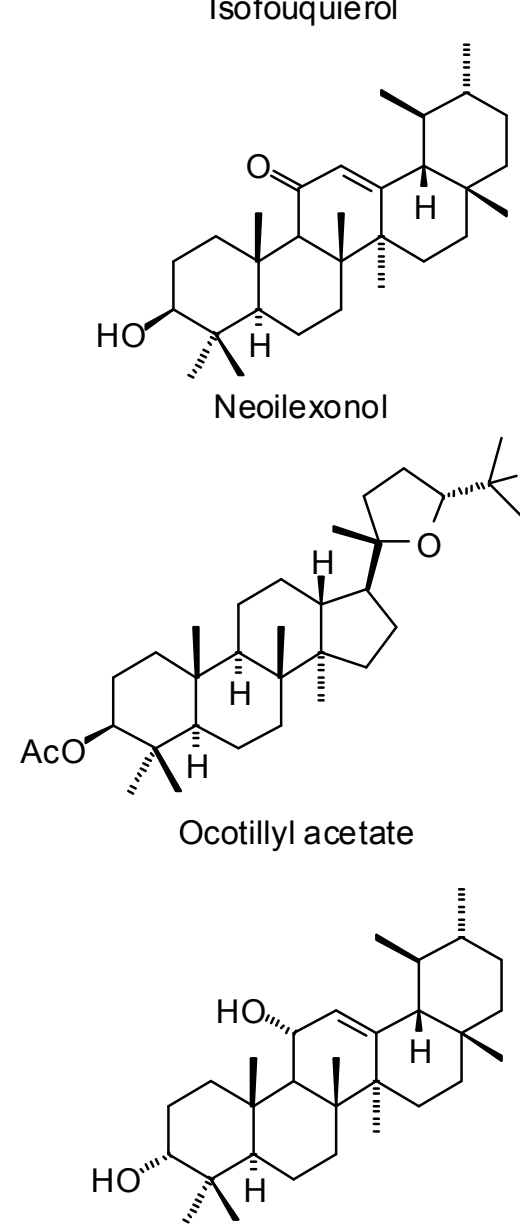

Urs-12-ene-3 $\alpha, 11 \alpha$-diol
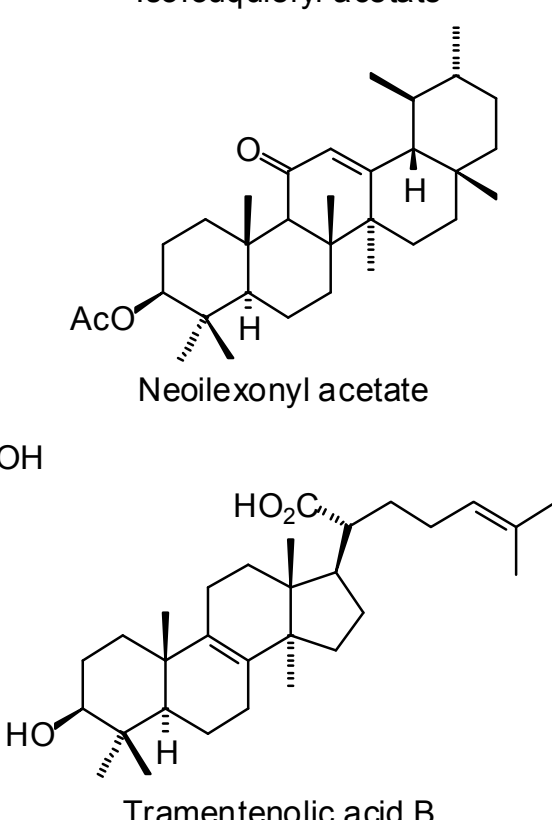

Lup-20(29)-ene-2 $\alpha, 3 \beta$-diol

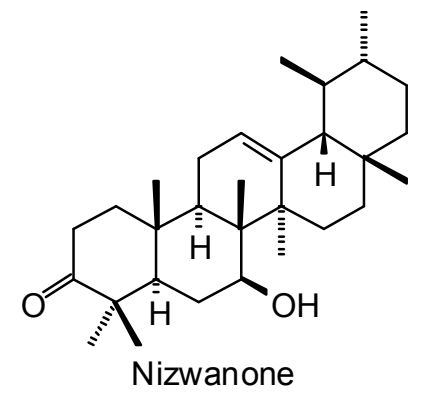<smiles>CC12CCC(C)(C)C(C)(O)C1C1=CCC3C4(C)CC[C@H](O)C(C)(C)C4CCC3(C)[C@]1(C)CC2</smiles>

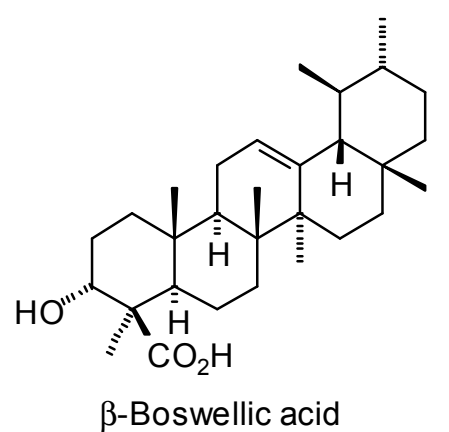

Figure 3. Cont. 
<smiles>CO[C@H]1C=C2C3CC(C)(C)CCC3(C)CC[C@]2(C)C2CCC3C(C)(CC[C@H](O)C3(C)C)C21</smiles>

Olibanumol E<smiles>CC12CC[C@H](C(C)(O)CO)C1C1CCC3[C@@]4(C)CC[C@H](O)C(C)(C)[C@H]4CC[C@@]3(C)[C@]1(C)CC2</smiles>

Olibanumol H<smiles>C=C(C)[C@H]1CCC2(C)CC[C@]3(C)C(CCC4[C@@]5(C)CC[C@H](C=O)[C@@](C)(O)[C@H]5CC[C@]43C)C12</smiles>

Olibanumol F<smiles>C=C(C)[C@H]1CCC2(C)CC[C@]3(C)C(CCC4C3CC[C@@]3(C)[C@]4(C)CC[C@H](O)[C@]3(C)O)C12</smiles>

Olibanumol G

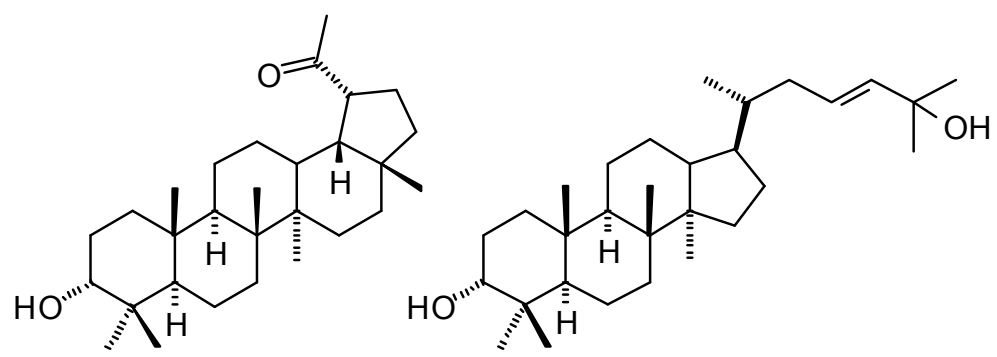

Olibanumol I

Olibanumol J

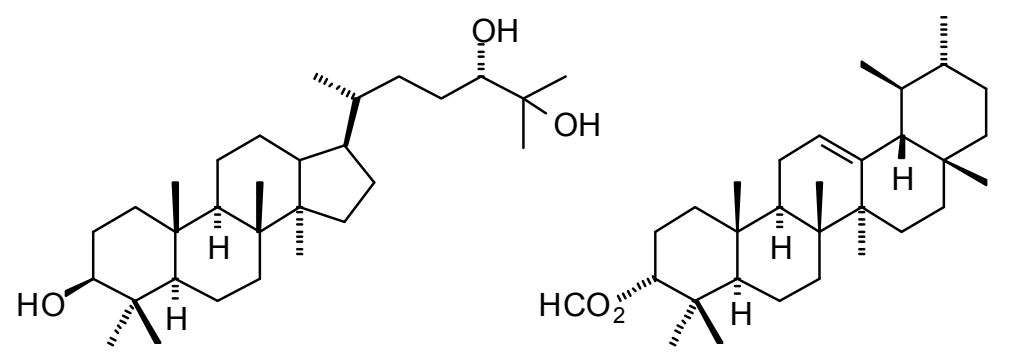

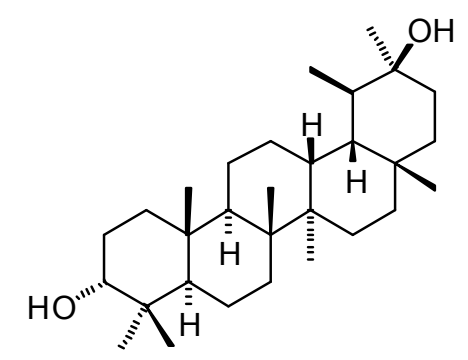

Olibanumol J'

Olibanumol K

Olibanumol L (= 3,20-Ursanediol)

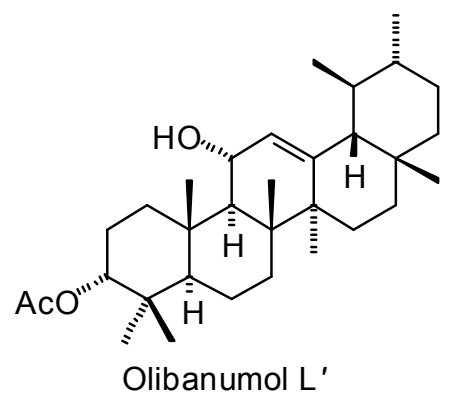

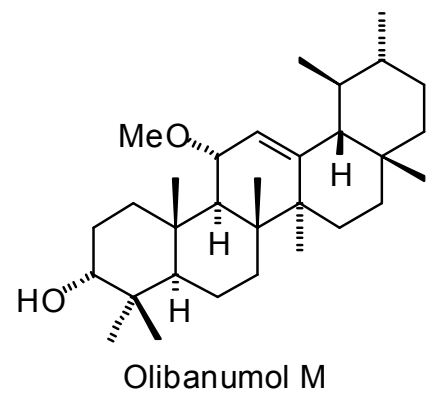

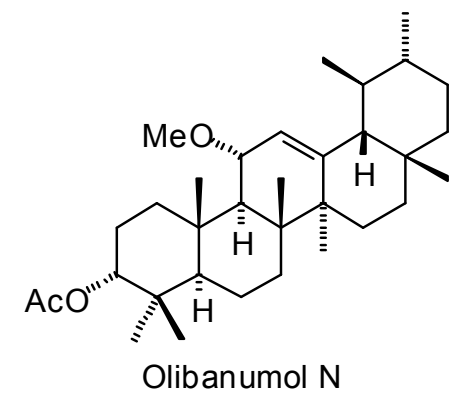

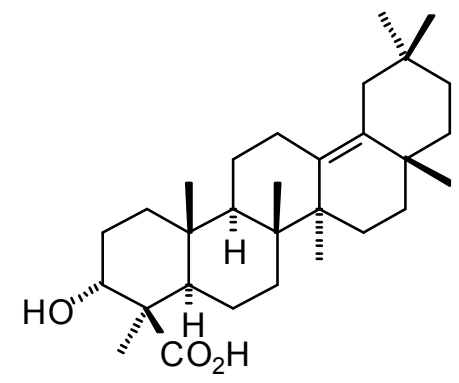

$\delta$-Boswellic acid<smiles>CC(C)=CCC[C@@H](C(=O)O)[C@H]1CC[C@]2(C)C3=C(CC[C@H]12)[C@@]1(C)CCC(=O)C(C)(C)[C@@]1(C)CCC3=O</smiles>

Figure 3. Triterpenoids isolated from Boswellia species. 


\section{Materials and Methods}

\subsection{Ligand Preparation}

Each ligand structure was prepared using Spartan'16 v. 2.0.7 (Wavefunction, Inc., Irvine, CA, USA). The lowest-energy conformations of the ligands were determined using the Merck Molecular Force Field (MMFF) [28]. In the case of the cembranoid macrocyclic ligands, further conformational analysis was carried out using density functional theory at the M06-2X/6-31G* level [29] with SM8 [30] aqueous solvent model [31].

\subsection{Reverse Molelcular Docking}

A reverse molecular docking study was carried out on each of the Bosellia terpenoids with the sc-PDB database of druggable binding sites [32]. Each compound was examined against the 16034 protein targets contained in the sc-PDB database. Prior to docking, all solvent molecules were removed from the protein structures. Co-crystallized enzyme cofactors were retained as cofactors and co-crystallized substrates or inhibitors were retained as ligands. Molecular docking was carried out using Molegro Virtual Docker v. 6.0.1 (Molegro ApS, Aarhus, Denmark) [33] as previously reported [34]. A python script was written to generate the Molegro input files; the jobs were run as a batch from the mvd.exe command line executable. The script took the co-crystallized ligands in each protein and wrote an input file that defined the search space for that docking as a sphere centered on the ligand's center of mass. A $15-\AA$ radius sphere was centered on the binding sites of each protein structure in order to permit each ligand to search. Standard protonation states of each protein, based on neutral $\mathrm{pH}$, were used and charges were assigned based on standard templates as part of the Molegro Virtual Docker program. Each protein was used as a rigid model without protein relaxation. Flexible-ligand models were used in the docking optimizations. Different orientations of the ligands were search and ranked based on their "rerank" energy scores. A total of 100 runs for each ligand were carried out.

\subsection{Conformational Analysis of Boscartol D}

All calculations were carried out using Spartan'16 for Windows (Wavefunction, Inc., Irvine, CA, USA). Conformational profiles were carried out using molecular mechanics with the MMFF force field. Conformations with relative energies $<20 \mathrm{~kJ} / \mathrm{mol}$ were re-evaluated, with geometry optimization, using density functional theory (DFT, M06-2X/6-31G $\left.{ }^{*}\right)$ with a nonpolar solvent $\left(\mathrm{CHCl}_{3}\right)$ model.

\section{Results and Discussion}

\subsection{Cembranoid Diterpenoids}

The macrocyclic cembranoid diterpenoids examined in this study are shown in Figure 1. The top-binding protein targets for each of the Boswellia cembranoids are summarized in Table 1. Included in Table 1 are the median docking energies for comparison. The top binding proteins for boscartin A were acetylcholinesterase (AChE) enzymes, Torpedo californica (TcAChE) and human (HsAChE). Boscartin B docked preferentially with human $N$-acetylgalactosaminyltransferase (HsGTA) as well as with the bacterial targets Serratia marcescens chitinase B (SmChiB), Helicobacter pylori peptide deformylase (HpPDF), and Mycobacterium tuberculosis 7,8-diaminopelargonic acid synthase (MtBioA). The proteins with the most exothermic docking for boscartin $\mathrm{C}$ were Escherichia coli aspartate transaminase (EcAspTA), murine acetylcholinesterase (MmAChE), and Daboia russelii (Russell's viper) phospholipase $\mathrm{A}_{2}$ (DrPLA2). Boscartin D showed excellent docking with TcAChE (PDB 2cek, $E_{\text {dock }}=-115.3 \mathrm{~kJ} / \mathrm{mol}$ ) and EcAspTA. The best protein targets for boscartin E were TcAChE, HpPDF, and MtBioA. Boscartin F showed preferential docking energies with human pyruvate kinase M2 (HsPKM2), TcAChE, and HpPDF. Boscartin G showed excellent docking properties with acetylcholinesterases TcAChE and HsAChE. The proteins with the most exothermic docking 
energies with boscartin $\mathrm{H}$ were human $N$-acetylgalactosaminyltransferase (HsGTA), DrPLA2, SmChiB, and MmAChE.

Table 1. Protein targets with the most exothermic docking energies $\left(E_{\mathrm{dock}}, \mathrm{kJ} / \mathrm{mol}\right)$ for Boswellia cembranoid ligands.

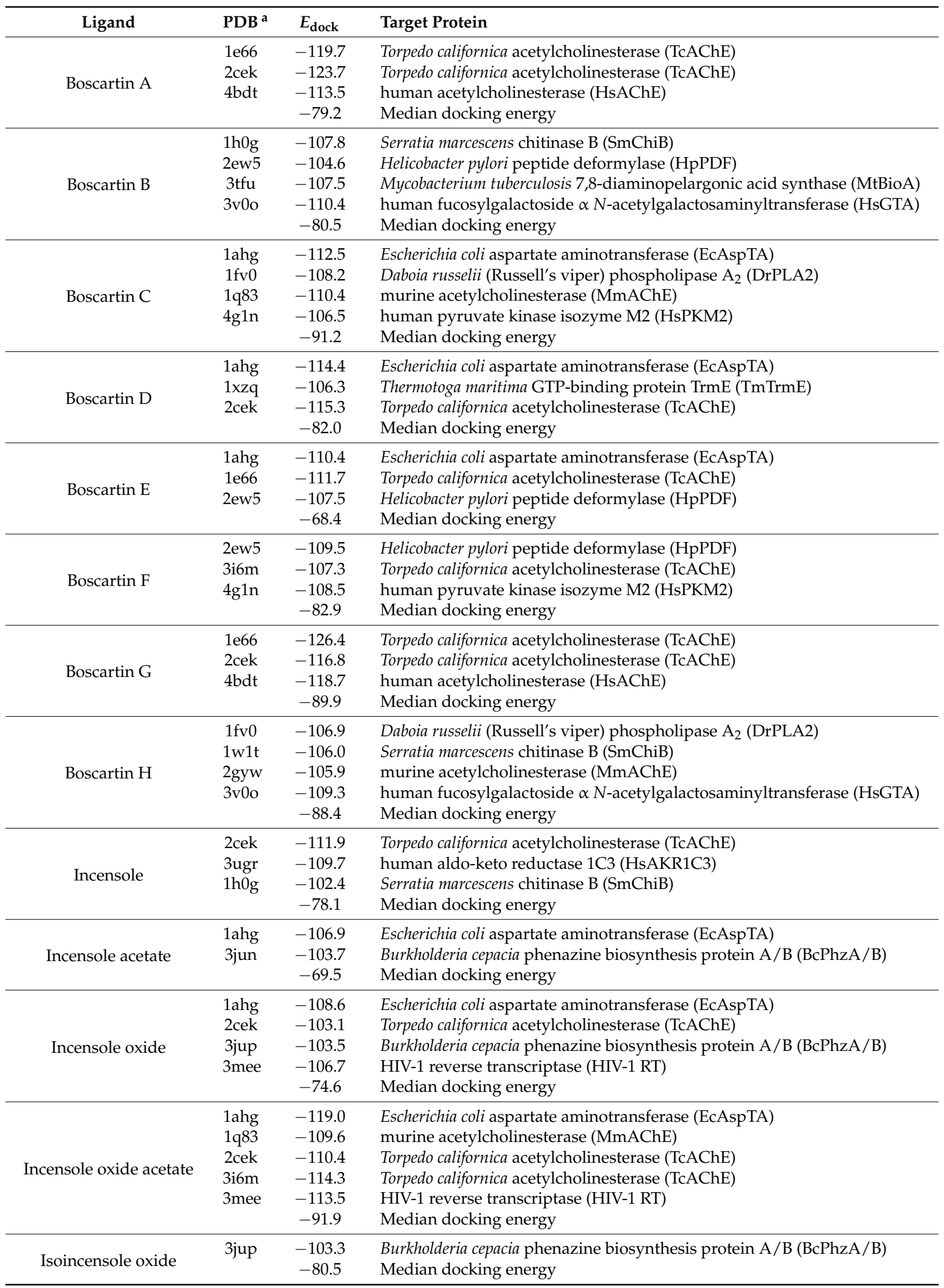


Table 1. Cont.

\begin{tabular}{|c|c|c|c|}
\hline Ligand & $\mathrm{PDB}^{\mathrm{a}}$ & $E_{\text {dock }}$ & Target Protein \\
\hline Isoincensolol & $\begin{array}{l}1 \mathrm{fv} 0 \\
1 \mathrm{jus} \\
2 \mathrm{qp} 4\end{array}$ & $\begin{array}{l}-108.2 \\
-107.9 \\
-102.2 \\
-74.0\end{array}$ & $\begin{array}{l}\text { Daboia russelii (Russell's viper) phospholipase } \mathrm{A}_{2} \text { (DrPLA2) } \\
\text { Staphylococcus aureus multidrug binding protein (SaQacR) } \\
\text { human dehydroepiandrosterone sulfotransferase (HsSULT2A1) } \\
\text { Median docking energy }\end{array}$ \\
\hline Serratol & $\begin{array}{l}1 \mathrm{e} 66 \\
2 \mathrm{cek} \\
2 \mathrm{ew} 5 \\
4 \mathrm{bdt}\end{array}$ & $\begin{array}{l}-104.1 \\
-106.1 \\
-103.2 \\
-103.0 \\
-78.1\end{array}$ & $\begin{array}{l}\text { Torpedo californica acetylcholinesterase (TcAChE) } \\
\text { Torpedo californica acetylcholinesterase (TcAChE) } \\
\text { Helicobacter pylori peptide deformylase (HpPDF) } \\
\text { human acetylcholinesterase (HsAChE) } \\
\text { Median docking energy }\end{array}$ \\
\hline Verticillatriene & $\begin{array}{l}1 \mathrm{w} 41 \\
3 \mathrm{i} 6 \mathrm{~m} \\
3 \mathrm{i} 6 \mathrm{z}\end{array}$ & $\begin{array}{l}-104.3 \\
-100.8 \\
-103.2 \\
-63.6\end{array}$ & $\begin{array}{l}\text { Torpedo californica acetylcholinesterase (TcAChE) } \\
\text { Torpedo californica acetylcholinesterase (TcAChE) } \\
\text { Torpedo californica acetylcholinesterase (TcAChE) } \\
\text { Median docking energy }\end{array}$ \\
\hline
\end{tabular}

Incensole docked well with TcAChE, human aldo-keto reductase 1C3 (HsAKR1C3), and SmChiB. Incensole acetate preferentially targeted bacterial proteins EcAspTA, HpPDF, and Burkholderia cepacia phenazine biosynthesis protein A/B (BcPhzA/B). The preferred protein targets for incensole oxide were EcAspTA, human immunodeficiency virus type 1 reverse transcriptase (HIV-1-RT), TcAChE, $\mathrm{BcPhzA} / \mathrm{B}$, and MtBioA. Incensole oxide acetate gave excellent docking energies to EcAspTA, TcAChE, MmAChE, and HIV-1-RT. Isoincensole oxide docked well to BcPzhA/B and TcAChE. The protein targets that showed the best docking energies with isoincensolol were DrPLA2, Staphylococcus aureus multidrug binding protein QacR (SaQacR), and human dehydroepiandrosterone sulfotransferase (HsSULT2A1).

Every cembranoid ligand showed excellent docking properties to acetylcholinesterases (Table 2). Acetylcholinesterase has been identified as a target for treatment of Alzheimer's disease [35]. This is notable because frankincense (Boswellia spp.) resins have been used in Persian traditional medicine as an anti-Alzheimer's agent [36,37]. Animal models (rat) of Alzheimer's disease [38-40] and human clinical trials [41,42] showed beneficial effects on memory with frankincense.

Table 2. MolDock molecular docking energies $(\mathrm{kJ} / \mathrm{mol})$ of Boswellia cembranoids with acetylcholinesterase protein targets. ${ }^{\mathrm{a}}$

\begin{tabular}{|c|c|c|c|c|c|c|c|c|c|}
\hline Ligand & TcAChE & TcAChE & TcAChE & TcAChE & TcAChE & TcAChE & MmAChE & MmAChE & HsAChE \\
\hline Boscartin A & -119.7 & -98.4 & -99.5 & -123.7 & -98.2 & -100.6 & -95.9 & -101.4 & -113.5 \\
\hline Boscartin C & -87.7 & -90.8 & -94.7 & -96.9 & -104.1 & -94.2 & -110.4 & -94.0 & -86.6 \\
\hline Boscartin D & -99.7 & -102.8 & -93.1 & -115.3 & -103.7 & -93.9 & -92.5 & -93.6 & -90.2 \\
\hline Boscartin E & -111.7 & -96.5 & -94.5 & -108.7 & -95.5 & -92.9 & -86.0 & -94.8 & -90.6 \\
\hline Boscartin G & -126.4 & -99.4 & -94.5 & -116.8 & -101.5 & -95.6 & -111.1 & -94.1 & -118.7 \\
\hline Boscartin $\mathrm{H}$ & -100.1 & -106.3 & -103.6 & -105.6 & -103.0 & -104.2 & -98.8 & -105.9 & -97.8 \\
\hline Incensole & -89.7 & -92.1 & -89.5 & -111.9 & -94.1 & -89.6 & -90.3 & -87.7 & -53.4 \\
\hline Incensole acetate & -88.6 & -97.2 & -102.8 & -102.5 & -102.3 & -101.7 & -87.5 & -85.0 & -42.3 \\
\hline Incensole oxide & -89.6 & -93.2 & -92.7 & -103.1 & -96.9 & -89.3 & -101.9 & -95.5 & -93.5 \\
\hline Incensole oxide acetate & -109.8 & -98.7 & -96.8 & -110.4 & -114.3 & -95.8 & -109.6 & -97.7 & -102.6 \\
\hline Verticillatriene & -82.5 & -91.2 & -104.3 & -85.3 & -100.8 & -103.2 & -73.9 & -98.1 & -61.2 \\
\hline
\end{tabular}

${ }^{\text {a }} \mathrm{TcAChE}=$ Torpedo californica acetylcholinesterase. MmAChE $=$ Mus musculus (murine) acetylcholinesterase. HsAChE = human acetylcholinesterase.

The lowest-energy docked pose of boscartin G with TcAChE (PDB 1e66, Figure 4A) shows the ligand to adopt the lowest-energy conformation as calculated by density functional theory at the 
M06-2X/6-31G*/SM8 level [31]. Key interactions between boscartin $\mathrm{G}$ and TcAChE are hydrophobic interactions between the ligand and aromatic amino acid side chains of Trp84, Phe330, and His440 (Figure 4B). In addition, there are hydrogen-bonding interactions between the oxirane ring of the ligand and the phenolic $-\mathrm{OH}$ of Tyr121 and the $\mathrm{C}(11)-\mathrm{OH}$ of the ligand and the peptide $\mathrm{C}=\mathrm{O}$ of His440 (Figure 4B).
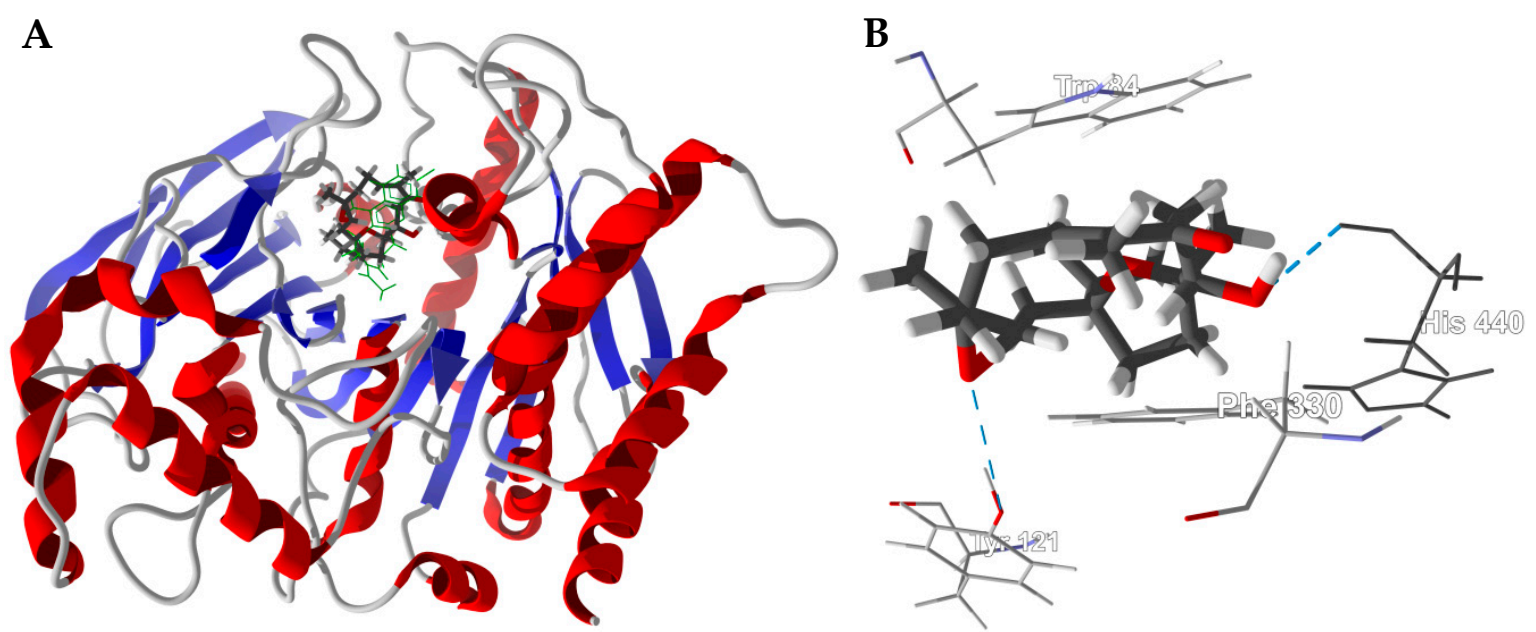

Figure 4. Lowest-energy docked pose of boscartin $\mathrm{G}$ with Torpedo californica acetylcholinesterase (TcAChE, PDB 1e66). (A): Ribbon structure of TcAChE with boscartin $G$ in the active site; the co-crystallized ligand (huprene $\mathrm{X}$ ) is shown as a green wire figure. (B): Key interactions of boscartin $\mathrm{G}$ with amino acids in the active site of TcAChE; hydrogen bonds are shown as blue dashed lines.

Boscartin A occupies the active site of TcAChE (Figure 5A, PDB 2cek). As observed for boscartin G with TcAChE, key interactions between the docked ligand and the protein are hydrophobic interactions with Trp84, Phe330, and His440, and a hydrogen-bond between the $\mathrm{C}(11)-\mathrm{OH}$ of the ligand and the His440 peptide $\mathrm{C}=\mathrm{O}$. The conformation of the lowest energy docked pose of boscartin A (Figure 5A) is the same as the lowest-energy calculated (M06-2X/6-31G*/SM8, Figure 5B) [31] and not that found in the X-ray crystal structure [13]. 

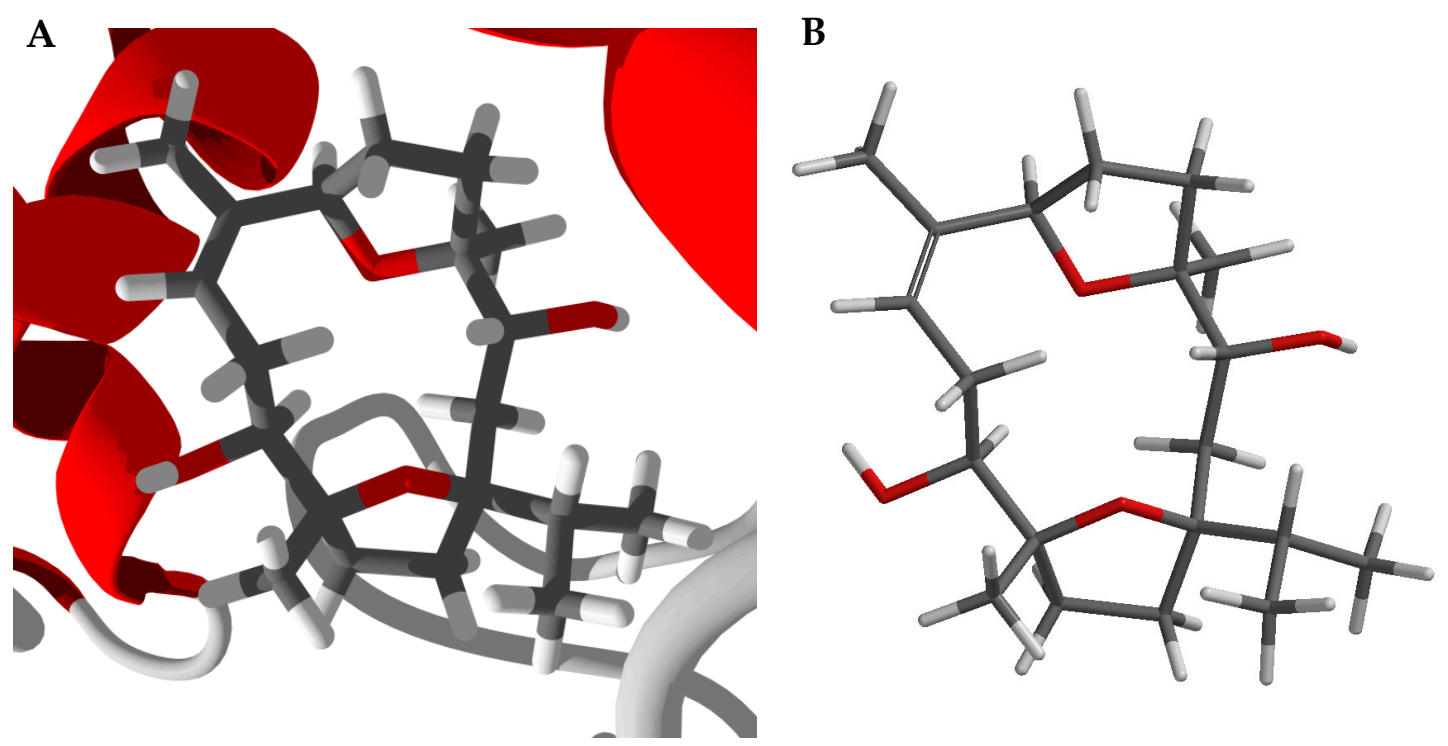

Figure 5. Boscartin A. (A): Lowest-energy docked pose of boscartin A with Torpedo californica acetylcholinesterase (PDB 2cek). (B): Calculated lowest-energy conformation of boscartin A at the M06-2X/6-31G*/SM8 level of theory [31].

A number of bacterial proteins were targeted by Boswellia cembranoids (Table 3). Helicobacter pylori peptide deformylase (HpPDF) and Escherichia coli aspartate transaminase (EcAspTA) were particularly well targeted, while boscartin $C$ and $E$ and incensole oxide acetate showed remarkably exothermic docking energies. Boswellia resin extracts have shown in-vitro antibacterial activity [43-45], and frankincense resins have been used traditionally to treat wounds [6,46] and for oral hygiene [8]. Furthermore, B. papyrifera resin has shown activity against methicillin-resistant Staphylococcus aureus (MRSA) [47] and B. serrata resin showed activity in a clinical trial against plaque-induced gingivitis [48]. The selective targeting of bacterial proteins by Boswellia cembranoids corroborates the traditional medicinal uses and the demonstrated antibacterial activities of frankincense.

The potent docking properties of Boswellia cembranoids with HpPDF are particularly noteworthy. There is a strong association between colonization of the human stomach by Helicobacter pylori and gastrointestinal illnesses such as chronic gastritis and peptic ulcers [49]. Frankincense has been used traditionally to treat stomach disturbances [4] and ulcers [46]. In addition, Boswellia extracts have been shown in clinical studies to be helpful in treating ulcerative colitis [50].

Boscartin $G$ is the strongest binding Boswellia cembranoid ligand with HpPDF (PDB 2ew5). The lowest-energy docked pose is shown in Figure 6. Boscartin G occupies the active site of HpPDF at the same location as the co-crystallized ligand, 4-\{(1E)-3-oxo-3-[(2-phenylethyl)amino]prop-1-en-1-yl\}-1,2-phenylene diacetate, a cavity surrounded by Ile45, Gly95, Glu94, His138, Cys96, and Gly46 (Figure 6B). The ligand forms two hydrogen-bonds with the peptide N-H groups of Ile45 and Gly46. The docked structure of boscartin $\mathrm{G}$ with HpPDF shows the same conformation (Figure 6C) as that predicted from DFT calculations (Figure 6D) [31]. 
Table 3. MolDock molecular docking energies $(\mathrm{kJ} / \mathrm{mol})$ of Boswellia cembranoids with bacterial target proteins. ${ }^{\text {a }}$

\begin{tabular}{|c|c|c|c|c|c|c|c|c|c|c|c|c|}
\hline \multirow{2}{*}{ Ligand } & EcAspTA & SmChiB & SmChiB & SmChiB & SaQacR & SaQacR & SaQacR & SaQacR & HpPDF & $\mathrm{BcPhzA} / \mathrm{B}$ & $\mathrm{BcPhzA} / \mathrm{B}$ & MtBioA \\
\hline & 1ahg & 1h0g & $1 w 1 t$ & $3 w d 2$ & 1jus & 1rpw & $3 b r 2$ & $3 b t i$ & 2ew5 & 3jun & 3jup & $3 t f u$ \\
\hline Boscartin A & -116.9 & -93.6 & -99.4 & -96.3 & -99.4 & -104.1 & -94.9 & -95.7 & -101.8 & -100.3 & -107.8 & -104.9 \\
\hline Boscartin B & -98.2 & -107.8 & -103.7 & -91.5 & -98.1 & -106.5 & -94.7 & -96.5 & -104.6 & -98.4 & -93.9 & -107.5 \\
\hline Boscartin C & -112.5 & -96.3 & -97.3 & -90.6 & -100.0 & -98.5 & -98.4 & -102.3 & -106.2 & -99.3 & -106.4 & -100.4 \\
\hline Boscartin D & -114.4 & -99.7 & -105.3 & -91.5 & -95.2 & -106.2 & -100.1 & -96.3 & -104.9 & -98.0 & -95.8 & -99.3 \\
\hline Boscartin E & -110.4 & -101.0 & -105.9 & -105.4 & -99.2 & -101.3 & -95.3 & -95.3 & -107.5 & -84.7 & -96.7 & -107.7 \\
\hline Boscartin F & -99.7 & -97.3 & -103.7 & -89.9 & -101.0 & -95.7 & -94.4 & -85.2 & -109.5 & -87.7 & -98.0 & -95.1 \\
\hline Boscartin G & -105.5 & -90.8 & -93.0 & -93.8 & -95.1 & -98.2 & -92.2 & -88.7 & -112.7 & -95.4 & -92.6 & -108.5 \\
\hline Boscartin $\mathrm{H}$ & -104.1 & -103.6 & -106.0 & -104.4 & -97.2 & -98.8 & -97.4 & -94.5 & -100.9 & -93.4 & -101.5 & -99.5 \\
\hline Incensole & -104.3 & -102.4 & -101.1 & -96.2 & -85.0 & -96.3 & -90.7 & -95.0 & -94.0 & -92.9 & -93.0 & -95.7 \\
\hline Incensole acetate & -109.9 & -102.3 & -96.2 & -98.1 & -96.6 & -104.5 & -96.1 & -98.8 & -96.2 & -103.7 & -91.5 & -96.2 \\
\hline Incensole oxide & -108.6 & -92.0 & -93.5 & -90.3 & -97.4 & -99.8 & -94.2 & -95.6 & -101.4 & -97.1 & -103.5 & -103.5 \\
\hline Incensole oxide acetate & -119.0 & -101.1 & -98.9 & -96.4 & -96.7 & -98.7 & -99.2 & -100.0 & -106.9 & -105.5 & -99.4 & -100.0 \\
\hline Isoincensole oxide & -96.2 & -87.6 & -93.5 & -89.9 & -98.5 & -97.5 & -98.5 & -92.7 & -88.9 & -87.5 & -103.3 & -91.2 \\
\hline Isoincensolol & -87.3 & -91.2 & -88.9 & -87.9 & -107.9 & -90.0 & -99.6 & -87.8 & -99.7 & -91.5 & -100.0 & -95.2 \\
\hline Serratol & -90.2 & -90.1 & -89.9 & -82.2 & -90.1 & -91.4 & -97.6 & -89.1 & -103.2 & -87.4 & -92.7 & -93.4 \\
\hline Verticillatriene & -74.0 & -69.5 & -69.0 & -69.5 & -81.2 & -87.2 & -85.5 & -78.5 & -77.3 & -76.5 & -89.9 & -84.4 \\
\hline
\end{tabular}

${ }^{\text {a }}$ EcAspTA $=$ Escherichia coli aspartate transaminase. SmChiB $=$ Serratia marcescens chitinase. SaQacR $=$ Staphylococcus aureus multidrug binding protein. $\mathrm{HpPDF}=$ Helicobacter pylori peptide

deformylase. $\mathrm{BcPhzA} / \mathrm{B}=$ Burkholderia cepacia phenazine biosynthesis protein A/B. MtBioA = Mycobacterium tuberculosis 7,8-diaminopelargonic acid synthase. 
A
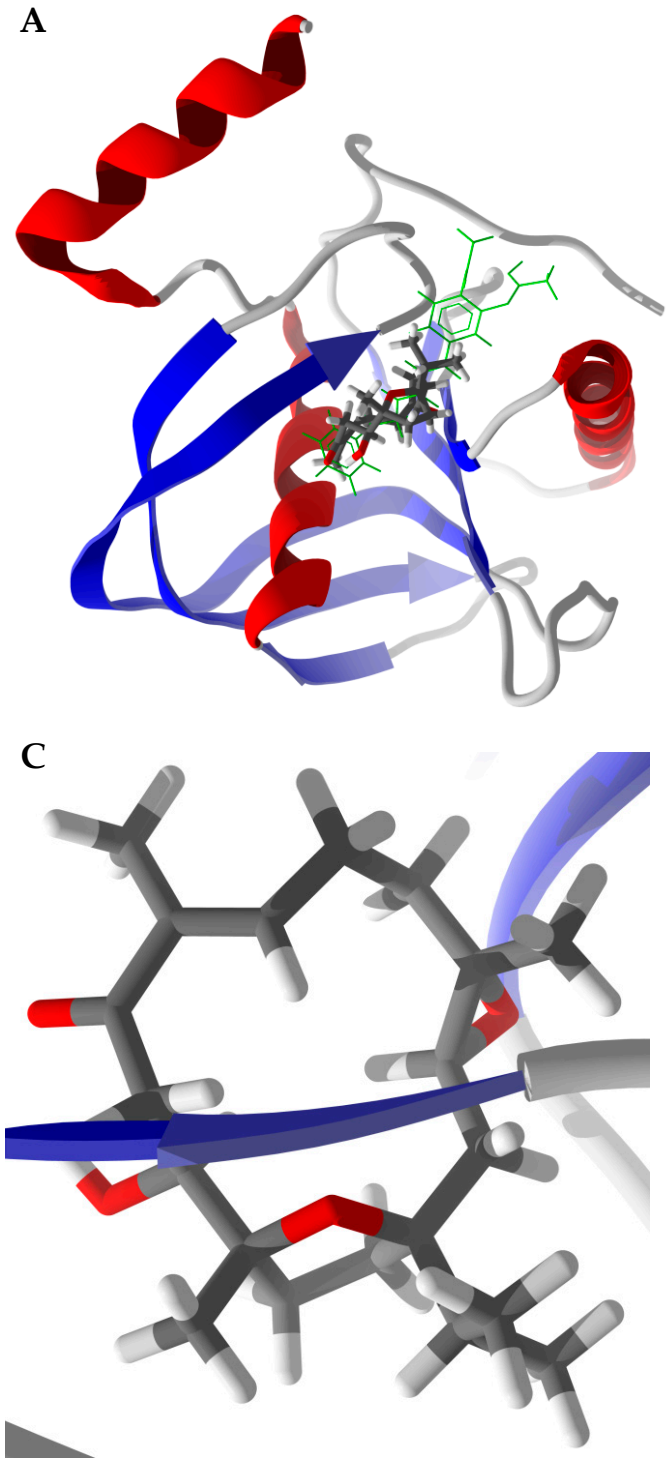
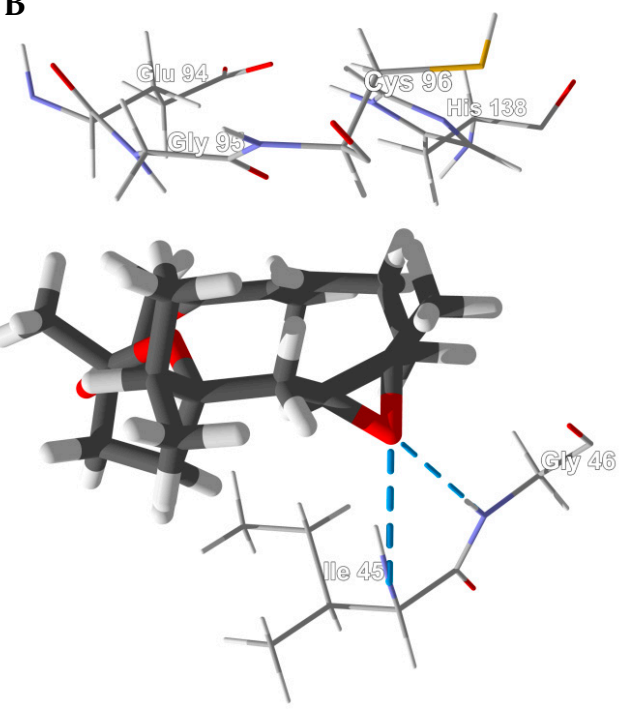

D

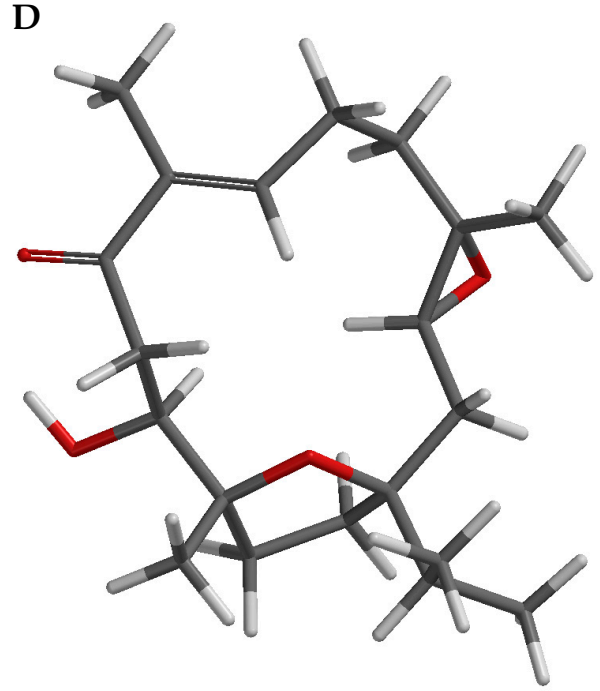

Figure 6. Docking of boscartin G with Helicobacter pylori peptide deformylase (HpPDF, PDB 2cek). (A): Ribbon structure of HpPDF showing boscartin G in the active site; the co-crystallized ligand, 4-\{(1E)-3-oxo-3-[(2-phenylethyl)amino]prop-1-en-1-yl\}-1,2-phenylene diacetate, is shown as a green stick figure. (B): Key interactions of boscartin $\mathrm{G}$ in the active site of HpPDF; hydrogen-bonds are shown as blue dashed lines. (C): Conformation of boscartin G docked to HpPDF. (D): Lowest-energy conformation of boscartin $G$ determined by density functional calculations (M06-2X/6-31G*/SM8) [31].

Several Boswellia cembranoids showed selective docking to HIV-1 reverse transcriptase (HIV1-RT) (Table 4). In particular, incensole oxide acetate showed excellent docking $\left(E_{\text {dock }}<-100 \mathrm{~kJ} / \mathrm{mol}\right)$ to four of the seven HIV1-RT protein crystal structures. The lowest-energy docked pose of incensole oxide acetate with HIV-1 reverse transcriptase (PDB 3mee) is shown in Figure 7. Key interactions between the ligand and the protein are Tyr181, Tyr188, Leu100, Trp229, and Lys103 (Figure 7B). Interestingly, the docking energies for the cembranoids to PDB 3lal and 3t19 are, on average, lower than for the other protein structures. The differences in docking energies can be attributed to the arrangements of the amino acid residues at the binding sites, resulting in different orientations of the docked ligands. Thus, for example, the key amino acids interacting with incensole oxide acetate in PDB 3lal are Tyr188, Leu100, Tyr181, Phe227, and Tyr318 (Figure 7C), while PDB 3t19 had Leu100, Tyr188, Val106, Tyr318, and Tyr181 (Figure 7D). That is, binding sites of the protein crystal structures are heavily influenced by 
the co-crystallized ligands. Both methanol and aqueous extracts of Boswellia carteri have demonstrated HIV-1 reverse transcriptase activity [51].

Table 4. MolDock molecular docking energies $(\mathrm{kJ} / \mathrm{mol})$ of Boswellia cembranoids with human immunodeficiency virus type 1 reverse transcriptase (HIV1-RT).

\begin{tabular}{cccccccc}
\hline Ligand & 1eet & 2hnz & 3irx & 3is9 & 3mee & 3lal & 3t19 \\
\hline Boscartin A & -99.1 & -101.7 & -96.8 & -93.8 & -96.0 & -69.4 & -75.4 \\
Boscartin B & -94.1 & -98.5 & -100.2 & -94.7 & -95.6 & -72.2 & -97.8 \\
Boscartin C & -104.2 & -91.5 & -97.0 & -101.3 & -100.5 & -87.8 & -84.0 \\
Boscartin D & -89.2 & -100.5 & -97.1 & -97.1 & -96.4 & -78.7 & -83.2 \\
Boscartin E & -97.2 & -100.6 & -91.7 & -97.0 & -89.4 & -60.8 & -72.0 \\
Boscartin F & -88.9 & -93.8 & -98.1 & -98.1 & -95.1 & -88.1 & -69.4 \\
Boscartin G & -92.8 & -88.7 & -97.6 & -95.4 & -113.8 & +9.3 & -82.3 \\
Boscartin H & -98.2 & -90.4 & -96.9 & -97.1 & -98.2 & -86.9 & -56.2 \\
Incensole & -83.8 & -101.5 & -88.8 & -88.3 & -86.8 & -84.0 & -94.7 \\
Incensole acetate & -95.6 & -92.6 & -97.9 & -97.0 & -84.6 & -95.9 & -91.6 \\
Incensole oxide & -105.1 & -93.2 & -94.9 & -98.7 & -106.7 & -81.7 & -79.0 \\
Incensole oxide acetate & -107.2 & -84.5 & -106.8 & -106.2 & -113.5 & -87.8 & -87.1 \\
Isoincensole oxide & -97.8 & -86.5 & -89.4 & -90.2 & -98.7 & -77.5 & -57.7 \\
Isoincensolol & -95.2 & -85.6 & -98.2 & -85.4 & -85.9 & -70.6 & -72.5 \\
Serratol & -90.4 & -87.9 & -86.8 & -89.3 & -90.1 & -56.0 & -48.9 \\
Verticillatriene & -81.6 & -67.1 & -78.4 & -81.0 & -82.5 & -76.9 & -25.5 \\
\hline
\end{tabular}

A

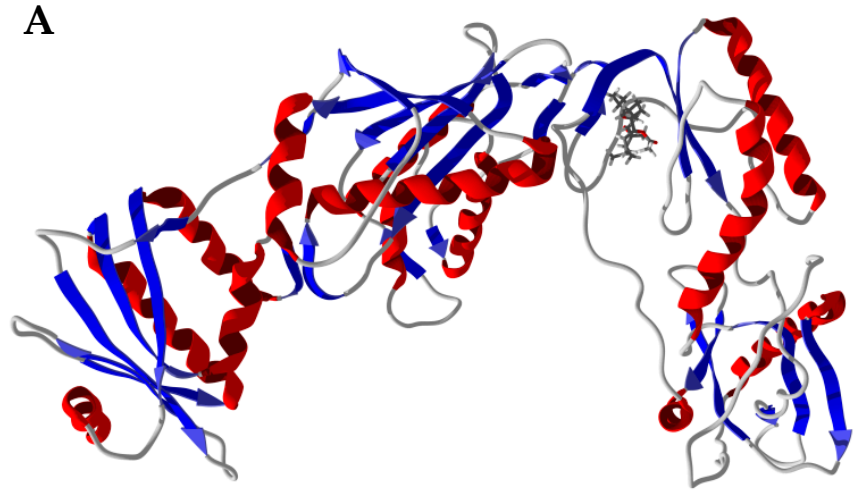

C

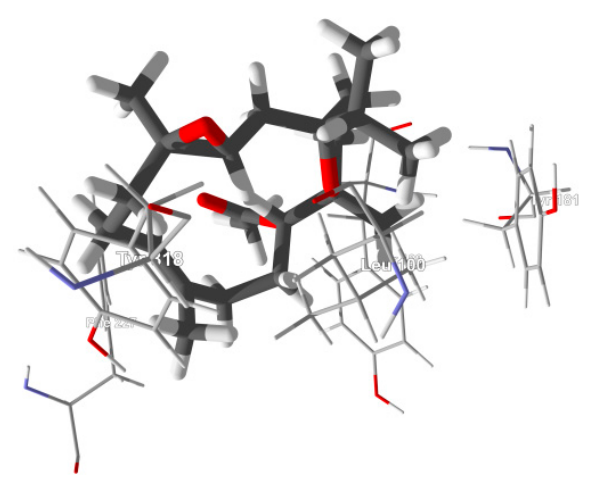

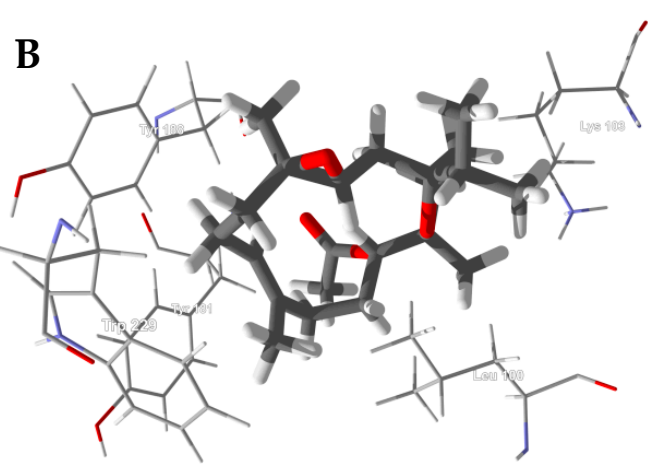

D

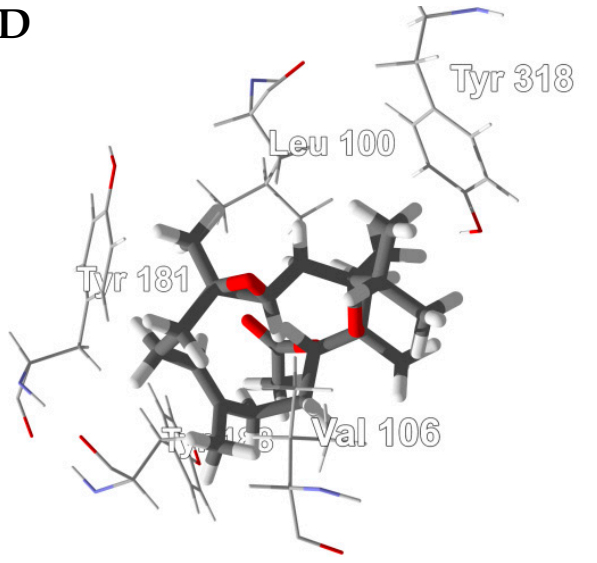

Figure 7. Molecular docking of incensole oxide acetate with HIV-1 reverse transcriptase. (A): Ribbon structure of HIV1-RT (PDB 3mee) showing incensole oxide acetate in the active site. (B): Key interactions of incensole oxide acetate in the active site of HIV1-RT (PDB 3mee). (C): Key interactions of incensole oxide acetate in the active site of HIV1-RT (PDB 3lal). (D): Key interactions of incensole oxide acetate in the active site of HIV1-RT (PDB 3t19). 


\subsection{Cneorubenoid Diterpenoids}

The cneorubenoid diterpenoids, boscartols A-I and olibanumol D, can be considered to be prenylated aromadendranes (Figure 2), and have been isolated from the oleo-gum resin of Boswellia carteri [21]. The absolute configuration of the $\mathrm{C}(15)$ of boscartol $\mathrm{D}$ was not experimentally determined [21]. Nevertheless, both diastereomers, (15R)-boscartol D and (15S)-boscartol D were used in the reverse docking. In addition, the stereochemistry of $C(15)$ was determined theoretically using density functional theory (DFT) conformational analysis carried out at the M06-2X/6-31G* level of theory, including a non-polar $\left(\mathrm{CHCl}_{3}\right)$ solvent model. A complete conformational analysis of (15R)-boscartol D was carried out giving 20 low-energy conformations $\left(E_{\text {rel }}<14.0 \mathrm{~kJ} / \mathrm{mol}\right.$, accounting for $100 \%$ of the Boltzmann distribution of conformers). Similarly, conformational analysis of (15S)-boscartol D returned 13 low-energy $\left(E_{\text {rel }}<13.0 \mathrm{~kJ} / \mathrm{mol}\right)$. For each of the conformations, the $\mathrm{H}-\mathrm{C}(15)-\mathrm{C}(16)-\mathrm{H}$ dihedral angle was determined and the corresponding vicinal coupling constants $\left({ }^{3} \mathrm{JHH}_{\mathrm{HH}}\right)$ calculated using both the original Karplus equation [52] and the Haasnoot/Altona generalized Karplus equation that includes correction terms for the electronegativity of substituents [53]. Accounting for the Boltzmann distribution, (15R)-boscartin D is predicted to have ${ }^{3} J_{\mathrm{HH}}$ of 4.3 and 5.1 $\mathrm{Hz}$, respectively. The (15S)-diastereomer, on the other hand, is calculated to have ${ }^{3} J_{\mathrm{HH}}$ of 6.3 and 6.5 $\mathrm{Hz}$, respectively. The reported ${ }^{3} \mathrm{~J}_{\mathrm{HH}}$ coupling constant was $7.6 \mathrm{~Hz}$ [21]. Based on the calculated ${ }^{3} \mathrm{~J}_{\mathrm{HH}}$ coupling constants, the stereochemistry of boscartol D is predicted to be (15S).

The protein targets that showed the best docking properties with Boswellia cneorubenoids are listed in Table 5, along with median docking energies. The protein that was best targeted by Boswellia cneorubenoids was Bacillus anthracis nucleotide adenylyltransferase (BaNadD, PDB 3hfj) with seven of the 11 ligands showing docking energies $<-120 \mathrm{~kJ} / \mathrm{mol}$. Human folate receptor $\beta$ (HsFR $\beta$, PDB $4 \mathrm{kn} 0$ and $4 \mathrm{kn} 1$ ) was also well targeted with $7 / 11$ cneorubenoids with $E_{\text {dock }}<-120 \mathrm{~kJ} / \mathrm{mol}$. The strongest docking ligands were boscartol $\mathrm{E}$ and boscartol I, and both of these ligands targeted BaNadD (PDB 3 $\mathrm{hfj}$ ) and HsFR $\beta$ (PDB $4 \mathrm{kn} 0$ ) very well.

Table 5. Protein targets with the most exothermic docking energies $\left(E_{\mathrm{dock}}, \mathrm{kJ} / \mathrm{mol}\right)$ for Boswellia cneorubenoid ligands.

\begin{tabular}{|c|c|c|c|}
\hline Ligand & $\mathrm{PDB}^{\mathrm{a}}$ & $E_{\text {dock }}$ & Target Protein \\
\hline Boscartol A & $\begin{array}{l}3 \mathrm{hfj} \\
4 \mathrm{kn} 0 \\
4 \mathrm{kn} 1\end{array}$ & $\begin{array}{l}-124.2 \\
-125.6 \\
-127.5 \\
-89.7\end{array}$ & $\begin{array}{l}\text { Bacillus anthracis nucleotide adenyltransferase (BaNadD) } \\
\text { human folate receptor } \beta(\mathrm{HsFR} \beta) \\
\text { human folate receptor } \beta(\mathrm{HsFR} \beta) \\
\text { Median docking energy }\end{array}$ \\
\hline Boscartol B & $\begin{array}{l}3 \mathrm{hfj} \\
4 \mathrm{kn} 0 \\
4 \mathrm{kn} 1\end{array}$ & $\begin{array}{l}-124.2 \\
-127.8 \\
-126.8 \\
-91.6\end{array}$ & $\begin{array}{l}\text { Bacillus anthracis nucleotide adenyltransferase (BaNadD) } \\
\text { human folate receptor } \beta(\mathrm{HsFR} \beta) \\
\text { human folate receptor } \beta(\mathrm{HsFR} \beta) \\
\text { Median docking energy }\end{array}$ \\
\hline Boscartol C & $3 b t 9$ & $\begin{array}{l}-120.2 \\
-85.8\end{array}$ & $\begin{array}{l}\text { Staphylococcus aureus multidrug binding protein (SaQacR) } \\
\text { Median docking energy }\end{array}$ \\
\hline (15R)-Boscartol D & $\begin{array}{l}2 \text { cek } \\
\text { 3bt9 } \\
\text { 3lal } \\
\text { 3t19 }\end{array}$ & $\begin{array}{l}-120.9 \\
-122.7 \\
-125.5 \\
-123.1 \\
-87.6\end{array}$ & $\begin{array}{l}\text { Torpedo californica acetylcholine esterase (TcAChE) } \\
\text { Staphylococcus aureus multidrug binding protein (SaQacR) } \\
\text { HIV-1 reverse transcriptase } \\
\text { HIV-1 reverse transcriptase } \\
\text { Median docking energy }\end{array}$ \\
\hline (15S)-Boscartol D & 3lal & $\begin{array}{l}-120.6 \\
-81.8\end{array}$ & $\begin{array}{l}\text { HIV-1 reverse transcriptase } \\
\text { Median docking energy }\end{array}$ \\
\hline Boscartol E & $\begin{array}{l}1 \mathrm{~s} 9 \mathrm{~d} \\
3 \mathrm{hjf} \\
4 \mathrm{~b} 80 \\
4 \mathrm{kn} 0\end{array}$ & $\begin{array}{l}-125.9 \\
-135.1 \\
-124.1 \\
-124.2 \\
-85.0\end{array}$ & $\begin{array}{l}\text { bovine guanine nucleotide exchange factor (BtGEF) } \\
\text { Bacillus anthracis nucleotide adenyltransferase (BaNadD) } \\
\text { murine acetylcholinesterase (MmAChE) } \\
\text { human folate receptor } \beta(\mathrm{HsFR} \beta) \\
\text { Median docking energy }\end{array}$ \\
\hline
\end{tabular}


Table 5. Cont.

\begin{tabular}{|c|c|c|c|}
\hline Ligand & PDB $^{\text {a }}$ & $E_{\text {dock }}$ & Target Protein \\
\hline Boscartol F & $\begin{array}{l}1 \mathrm{~s} 9 \mathrm{~d} \\
3 \mathrm{hfj} \\
4 \mathrm{kn} 1\end{array}$ & $\begin{array}{l}-124.5 \\
-123.1 \\
-122.3 \\
-84.6\end{array}$ & $\begin{array}{l}\text { bovine guanine nucleotide exchange factor (BtGEF) } \\
\text { Bacillus anthracis nucleotide adenyltransferase (BaNadD) } \\
\text { human folate receptor } \beta(\mathrm{HsFR} \beta) \\
\text { Median docking energy }\end{array}$ \\
\hline Boscartol G & 3hfj & $\begin{array}{l}-125.8 \\
-80.3\end{array}$ & $\begin{array}{l}\text { Bacillus anthracis nucleotide adenylyltransferase (BaNadD) } \\
\text { Median docking energy }\end{array}$ \\
\hline Boscartol H & $\begin{array}{l}1 \mathrm{dx} 4 \\
3 \mathrm{bt} 9 \\
3 \mathrm{hfj} \\
4 \mathrm{kn} 0\end{array}$ & $\begin{array}{l}-123.6 \\
-122.0 \\
-127.9 \\
-124.6 \\
-85.9\end{array}$ & $\begin{array}{l}\text { Drosophila melanogaster acetylcholine esterase (DmAChE) } \\
\text { Staphylococcus aureus multidrug binding protein (SaQacR) } \\
\text { Bacillus anthracis nucleotide adenyltransferase (BaNadD) } \\
\text { human folate receptor } \beta \text { (HsFR } \beta) \\
\text { Median docking energy }\end{array}$ \\
\hline Boscartol I & $\begin{array}{l}3 \mathrm{hfj} \\
3 \mathrm{p} 2 \mathrm{v} \\
4 \mathrm{kn} 0\end{array}$ & $\begin{array}{l}-133.8 \\
-121.1 \\
-127.3 \\
-91.4\end{array}$ & $\begin{array}{l}\text { Bacillus anthracis nucleotide adenyltransferase (BaNadD) } \\
\text { human aldose reductase (HsAR) } \\
\text { human folate receptor } \beta \text { (HsFR } \beta) \\
\text { Median docking energy }\end{array}$ \\
\hline Olibanumol D & $4 \mathrm{kn} 1$ & $\begin{array}{l}-120.6 \\
-78.4\end{array}$ & $\begin{array}{l}\text { human folate receptor } \beta(\operatorname{HsFR} \beta) \\
\text { Median docking energy }\end{array}$ \\
\hline
\end{tabular}

Nicotinate mononucleotide adenylyltransferase (NadD) has been identified as a target for development of antibacterial agents. The excellent docking of cneorubenoids with BaNadD, along with the known antibacterial activity of frankincense [43-45], corroborates the traditional uses of frankincense to treat wounds $[6,46]$.

Bacillus anthracis NadD (PDB 3hfj) is a dimeric structure with the active site at the interface of the two protein monomers (Figure 8). The active site is a hydrophobic pocket formed by Trp116A, Trp116B, Tyr112A, Tyr112B, Lys115A, and Lys115B (Figure 8B).

A

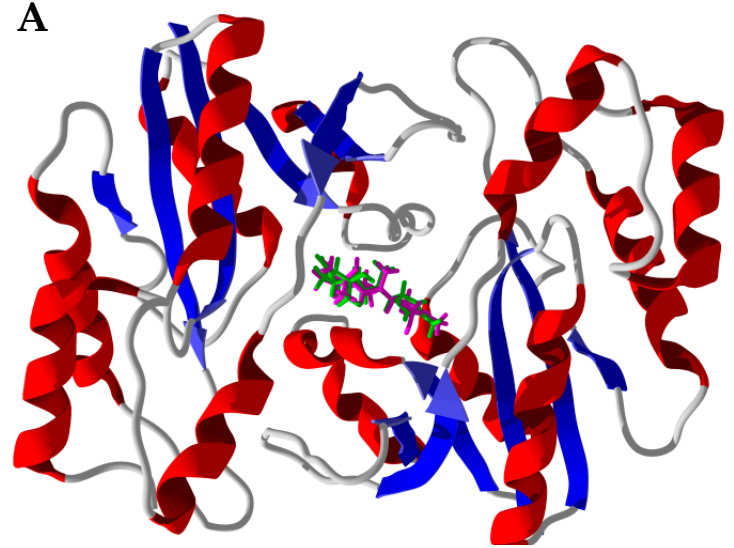

B

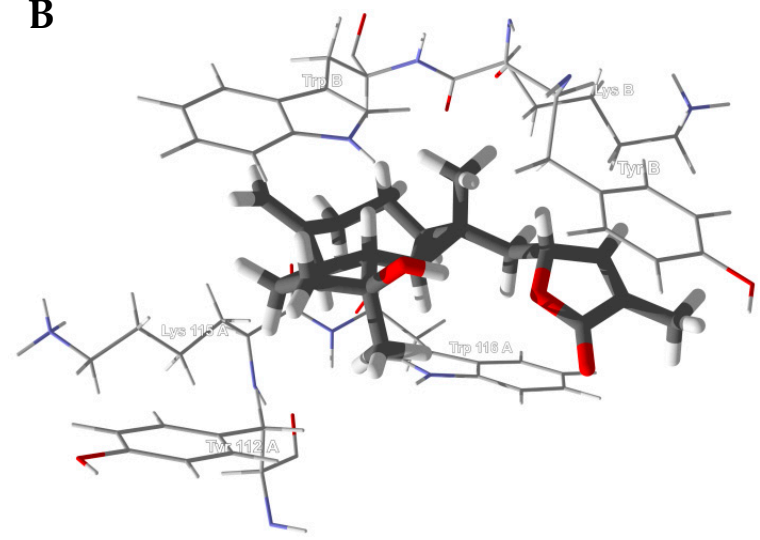

Figure 8. Bacillus anthracis nucleotide adenylyltransferase (BaNadD, PDB 3hfj). (A): Lowest-energy docked poses of boscartol E (magenta) and boscartol I (green) in the active site of the dimeric enzyme. (B): Boscartol I in the hydrophobic pocket formed at the interface of the two protein monomers.

Human folate receptor $\beta(\mathrm{HsFR} \beta)$ is overexpressed in activated macrophages associated with pathogenesis of inflammatory and autoimmune diseases [54] as well as neoplastic tissues [55]. Thus, antifolates that target folate receptors could be useful for the treatment of cancer and inflammatory diseases [56]. Clinical trials have demonstrated the encouraging results of frankincense treatment for inflammatory and autoimmune diseases such as rheumatoid arthritis, osteoarthritis, Crohn's disease, 
and collagenous colitis [57]. Boswellia cneorubenoids may be playing a role in the anti-inflammatory activity of frankincense.

The boscartols docked with HsFR $\beta$ in the folate binding site (Figure 9). The cyclopropazulane ring is surrounded by aromatic amino acids Trp187, Tyr101, Tyr76, and Phe78 (Figure 9B). In the case of boscartol A and boscartol B, the terminal -OH group is held in place by hydrogen bonds to Ser73 and Phe78 (Figure 9B).
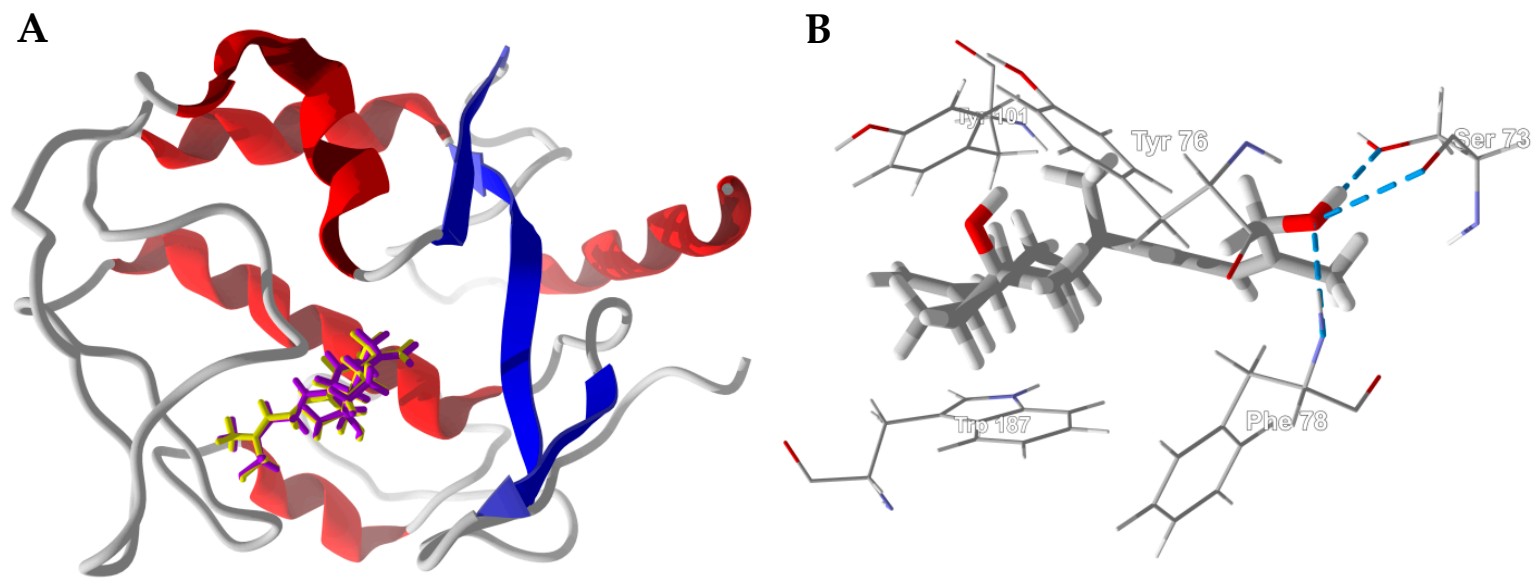

Figure 9. Human folate receptor $\beta$ (HsFR $\beta, \operatorname{PDB} 4 \mathrm{kn} 1)$. (A): Ribbon structure of protein showed the docked poses of boscartin A (yellow) and boscartin B (purple). (B): Lowest-energy docked pose of boscartin A in the binding site of HsFR $\beta$. Hydrogen-bonds are shown as blue dashed lines.

\subsection{Boswellia Triterpenoids}

The Boswellia triterpenoids examined in this reverse docking study are shown in Figure 3 and the target proteins with the best docking energies for each triterpenoid ligand are summarized in Table 6 . The most receptive protein targets for Boswellia triterpenoids were Staphylococcus aureus multidrug binding protein (SaQacR, PDB 3bt9) with an average docking energy $\left(E_{\text {dock }}\right)$ of $-111.9 \mathrm{~kJ} / \mathrm{mol}$ and human fibroblast collagenase (PDB $1 \mathrm{cgl})$ with an average docking energy $\left(E_{\text {dock }}\right)$ of $-110.5 \mathrm{~kJ} / \mathrm{mol}$.

Table 6. Protein targets with the most exothermic docking energies $\left(E_{\mathrm{dock}}, \mathrm{kJ} / \mathrm{mol}\right)$ for Boswellia triterpenoid ligands.

\begin{tabular}{|c|c|c|c|}
\hline Ligand & PDB $^{a}$ & $E_{\text {dock }}$ & Target \\
\hline (20S)-3,7-Dioxotirucalla-8,24-dien-21-oic acid & $\begin{array}{l}313 \mathrm{~m} \\
3 \text { ua9 } \\
3 \mathrm{~g} 49 \\
2 \mathrm{~b} 03\end{array}$ & $\begin{array}{l}-141.8 \\
-140.3 \\
-132.4 \\
-127.4 \\
-91.3\end{array}$ & $\begin{array}{l}\text { Human poly(ADP-ribose) polymerase-1 (HsPARP-1) (anticancer target) } \\
\text { Human tankyrase-2 (HsTANK2) = human poly(ADP-ribose) polymerase-5b (HsPARP-5b) (antitumor target) } \\
\text { Cavia porcellus } 11 \beta \text {-hydroxysteroid dehydrogenase type } 1 \text { (Cp11ßHSD1) (diabetes target) } \\
\text { Porcine pancreatic phospholipase A2 (SsPLA2) (anti-inflammatory target) } \\
\text { Median docking energy }\end{array}$ \\
\hline 11-Ethoxy- $\beta$-boswellic acid & $3 \mathrm{i} 6 \mathrm{~m}$ & $\begin{array}{l}-124.6 \\
-63.0\end{array}$ & $\begin{array}{l}\text { Torpedo californica acetylcholinesterase (TcAChE) (Alzheimer's target) } \\
\text { Median docking energy }\end{array}$ \\
\hline 11-Keto- $\beta$-boswellic acid & $\begin{array}{l}4 \mathrm{~b} 84 \\
3 \mathrm{i} 6 \mathrm{~m}\end{array}$ & $\begin{array}{l}-125.3 \\
-120.8 \\
-59.9 \\
\end{array}$ & $\begin{array}{l}\text { Murine acetylcholinesterase (MmAChE) (Alzheimer's target) } \\
\text { Torpedo californica acetylcholinesterase (TcAChE) (Alzheimer's target) } \\
\text { Median docking energy }\end{array}$ \\
\hline 12-Ursen-3,11-dione & $1 \mathrm{~h} 22$ & $\begin{array}{l}-118.8 \\
-64.2\end{array}$ & $\begin{array}{l}\text { Torpedo californica acetylcholinesterase (TcAChE) (Alzheimer's target) } \\
\text { Median docking energy }\end{array}$ \\
\hline 12-Ursen-3,24-diol & $1 \mathrm{~h} 22$ & $\begin{array}{l}-123.8 \\
+17.4\end{array}$ & $\begin{array}{l}\text { Torpedo californica acetylcholinesterase (TcAChE) (Alzheimer's target) } \\
\text { Median docking energy }\end{array}$ \\
\hline 2,3-Dihydroxy-12-ursen-24-oic acid & $4 \mathrm{~b} 84$ & $\begin{array}{l}-128.0 \\
+16.2 \\
\end{array}$ & $\begin{array}{l}\text { Murine acetylcholinesterase (MmAChE) (Alzheimer's target) } \\
\text { Median docking energy }\end{array}$ \\
\hline 24-Nor-3,9(11),12-oleanatriene & $31 \mathrm{z} 6$ & $\begin{array}{l}-112.6 \\
-31.2\end{array}$ & $\begin{array}{l}\text { Cavia porcellus } 11 \beta \text {-hydroxysteroid dehydrogenase type } 1 \text { (Cp11ßHSD1) (diabetes target) } \\
\text { Median docking energy }\end{array}$ \\
\hline 24-Nor-3,9(11),12-ursatriene & $1 \mathrm{~h} 22$ & $\begin{array}{l}-118.4 \\
+15.1\end{array}$ & $\begin{array}{l}\text { Torpedo californica acetylcholinesterase (TcAChE) (Alzheimer's target) } \\
\text { Median docking energy }\end{array}$ \\
\hline
\end{tabular}


Table 6. Cont

\begin{tabular}{|c|c|c|c|}
\hline Ligand & PDB ${ }^{a}$ & $E_{\text {dock }}$ & $\begin{array}{c}\text { Target } \\
\end{array}$ \\
\hline 3-Acetoxy-12,20(29)-lupadien-24-oic acid & $\begin{array}{c}1 \mathrm{uk} 1 \\
3 \mathrm{bti}\end{array}$ & $\begin{array}{l}-118.4 \\
-117.9 \\
+16.4\end{array}$ & $\begin{array}{l}\text { Human poly(ADP-ribose) polymerase-1 (HsPARP-1) (anticancer target) } \\
\text { Staphylococcus aureus multidrug binding protein (SaQacR) } \\
\text { Median docking energy }\end{array}$ \\
\hline $\begin{array}{l}\text { 3-Acetoxy-20(29)-lupen-24-oic acid (= 3-Acetyl } \\
\text { lupeolic acid) }\end{array}$ & $1 \mathrm{cgl}$ & $\begin{array}{l}-117.5 \\
+8.0\end{array}$ & $\begin{array}{l}\text { Human fibroblast collagenase (HsMMP-1) (arthritis target) } \\
\text { Median docking energy }\end{array}$ \\
\hline $\begin{array}{l}3 \beta \text {-Acetoxy-20S,24R-dihydroxydammar- } \\
25 \text {-ene }{ }^{\text {b }}\end{array}$ & $\begin{array}{l}2 \mathrm{aba} \\
3 \mathrm{lz} 6 \\
1 \mathrm{~h} 36\end{array}$ & $\begin{array}{l}-144.7 \\
-141.8 \\
-136.4 \\
-64.6\end{array}$ & $\begin{array}{l}\text { Enterobacter cloacae pentaerythritol tetranitrate reductase (EcPETNR) (antibacterial target) } \\
\text { Cavia porcellus } 11 \beta \text {-hydroxysteroid dehydrogenase type } 1 \text { (Cp11ßHSD1) (diabetes target) } \\
\text { Alicyclobacillus acidocardarius oxidosqualene cyclase (Aa OSC) (cholesterol-lowering) } \\
\text { Median docking energy }\end{array}$ \\
\hline $\begin{array}{l}3 \beta \text {-Acetoxy-20S,24S-dihydroxydammar- } \\
25 \text {-ene }{ }^{b}\end{array}$ & $\begin{array}{l}2 \mathrm{aba} \\
3 \mathrm{~g} 49 \\
3 \mathrm{lz} 6 \\
3 \mathrm{tfu}\end{array}$ & $\begin{array}{l}-149.9 \\
-139.7 \\
-136.2 \\
-134.5 \\
-73.7\end{array}$ & 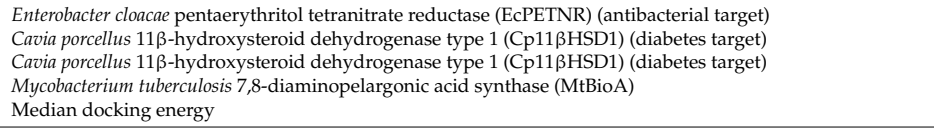 \\
\hline 3-Acetoxy-5,12-ursadien-24-oic acid & $3 \mathrm{i} 6 \mathrm{~m}$ & $\begin{array}{l}-131.7 \\
-66.7\end{array}$ & $\begin{array}{l}\text { Torpedo californica acetylcholinesterase (TcAChE) (Alzheimer's target) } \\
\text { Median docking energy }\end{array}$ \\
\hline 3-Acetyl-11-keto- $\beta$-boswellic acid & $3 \mathrm{i} 6 \mathrm{~m}$ & $\begin{array}{l}-129.7 \\
-70.7\end{array}$ & $\begin{array}{l}\text { Torpedo californica acetylcholinesterase (TcAChE) (Alzheimer's target) } \\
\text { Median docking energy }\end{array}$ \\
\hline 3-Acetyl-11 $\alpha$-methoxy- $\beta$-boswellic_acid & $3 \mathrm{i} 6 \mathrm{~m}$ & $\begin{array}{l}-129.0 \\
-72.2 \\
\end{array}$ & $\begin{array}{l}\text { Torpedo californica acetylcholinesterase (TcAChE) (Alzheimer's target) } \\
\text { Median docking energy }\end{array}$ \\
\hline 3-Acetyl-9,11-dehydro- $\beta$-boswellic_acid & $3 \mathrm{i} 6 \mathrm{~m}$ & $\begin{array}{l}-124.0 \\
-64.4 \\
\end{array}$ & $\begin{array}{l}\text { Torpedo californica acetylcholinesterase (TcAChE) (Alzheimer's target) } \\
\text { Median docking energy }\end{array}$ \\
\hline 3-Acetyl- $\alpha$-boswellic acid & $2 \mathrm{~b} 03$ & $\begin{array}{l}-112.7 \\
-64.8\end{array}$ & $\begin{array}{l}\text { Porcine pancreatic phospholipase A2 (SsPLA2) (anti-inflammatory target) } \\
\text { Median docking energy }\end{array}$ \\
\hline 3-Acetyl- $\beta$-boswellic acid & $3 \mathrm{i} 6 \mathrm{~m}$ & $\begin{array}{l}-128.3 \\
-71.5\end{array}$ & $\begin{array}{l}\text { Torpedo californica acetylcholinesterase (TcAChE) (Alzheimer's target) } \\
\text { Median docking energy }\end{array}$ \\
\hline $\begin{array}{l}\text { 3-Hydroxy-20(29)-lupen-24-oic acid (= Lupeolic } \\
\text { acid) }\end{array}$ & $3 b \operatorname{tg}$ & $\begin{array}{l}-119.3 \\
-55.8\end{array}$ & $\begin{array}{l}\text { Staphylococcus aureus multidrug binding protein (SaQacR) } \\
\text { Median docking energy }\end{array}$ \\
\hline 3-Oxotirucalla-7,9(11),24-trien-21-oic acid & $\begin{array}{l}\text { 3ua9 } \\
313 \mathrm{~m} \\
3 \mathrm{~h} 6 \mathrm{k} \\
1 \mathrm{w} 6 \mathrm{j} \\
3 \mathrm{btg}\end{array}$ & $\begin{array}{l}-151.0 \\
-137.6 \\
-130.9 \\
-127.5 \\
-127.1 \\
-96.8\end{array}$ & $\begin{array}{l}\text { Human tankyrase-2 (HsTANK2) = human poly(ADP-ribose) polymerase-5b (HsPARP-5b) (antitumor target) } \\
\text { Human poly(ADP-ribose) polymerase-1 (HsPARP-1) (anticancer target) } \\
\text { Human } 11 \beta \text {-hydroxysteroid dehydrogenase type } 1 \text { (11ßHSD1) (diabetes target) } \\
\text { Human oxidosqualene cyclase (HsOSC) (hypercholesterolemia target) } \\
\text { Staphylococcus aureus multidrug binding protein (SaQacR) } \\
\text { Median docking energy }\end{array}$ \\
\hline 3ß-Hydroxytirucalla-8,24-dien-21-oic acid & $\begin{array}{c}\text { 3ua9 } \\
313 \mathrm{~m} \\
3 \mathrm{~g} 49 \\
2 \mathrm{ilt} \\
4 \mathrm{krs} \\
410 \mathrm{i}\end{array}$ & $\begin{array}{l}-144.5 \\
-133.0 \\
-132.3 \\
-129.1 \\
-127.7 \\
-127.3 \\
-85.6\end{array}$ & 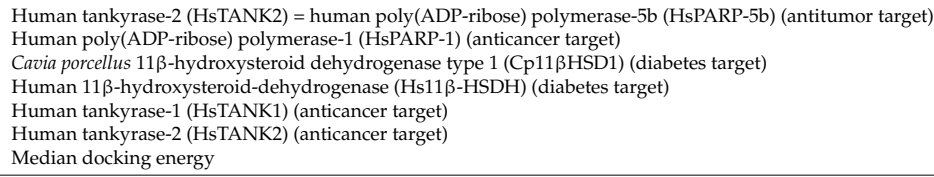 \\
\hline $3 \alpha$-Acetoxytirucalla-7,24-dien-21-oic acid & $\begin{array}{l}\text { 3ua9 } \\
4 \mathrm{krs} \\
1 \mathrm{cgl} \\
4 \mathrm{gv0} 0 \\
410 \mathrm{i} \\
3 \text { lep }\end{array}$ & $\begin{array}{l}-147.1 \\
-134.1 \\
-129.9 \\
-128.4 \\
-128.4 \\
-126.8 \\
-102.1 \\
\end{array}$ & $\begin{array}{l}\text { Human tankyrase-2 (HsTANK2) = human poly(ADP-ribose) polymerase-5b (HsPARP-5b) (antitumor target) } \\
\text { Human tankyrase-1 (HsTANK1) (anticancer target) } \\
\text { Human fibroblast collagenase (HsMMP-1) (arthritis target) } \\
\text { Human poly(ADP-ribose) polymerase-1 (HsPARP-1) (anticancer target) } \\
\text { Human tankyrase-2 (HsTANK2) (anticancer target) } \\
\text { Human aldose reductase (HsAR) (diabetes target) } \\
\text { Median docking energy }\end{array}$ \\
\hline $3 \alpha$-Hydroxytirucalla-7,24-dien-21-oic acid & $\begin{array}{l}\text { 3ua9 } \\
\text { 3g49 } \\
313 \mathrm{~m} \\
3 \mathrm{tfu}\end{array}$ & $\begin{array}{l}-154.3 \\
-128.9 \\
-126.7 \\
-126.4 \\
-88.7\end{array}$ & $\begin{array}{l}\text { Human tankyrase-2 (HsTANK2) }=\text { human poly(ADP-ribose) polymerase-5b (HsPARP-5b) (antitumor target) } \\
\text { Cavia porcellus } 11 \beta \text {-hydroxysteroid dehydrogenase type } 1 \text { (Cp11 } 1 \text { HSD1) (diabetes target) } \\
\text { Human poly(ADP-ribose) polymerase-1 (HsPARP-1) (anticancer target) } \\
\text { Mycobacterium tuberculosis 7,8-diaminopelargonic acid synthase (MtBioA) } \\
\text { Median docking energy }\end{array}$ \\
\hline $3 \beta$-Acetoxydammar-24-ene-16 $\beta, 20 R$-diol & $\begin{array}{l}3 \mathrm{lz} 6 \\
2 \mathrm{aba} \\
1 \mathrm{~h} 36 \\
1 \mathrm{~s} 0 \mathrm{x}\end{array}$ & $\begin{array}{l}-149.6 \\
-141.1 \\
-139.2 \\
-131.2 \\
-54.0\end{array}$ & $\begin{array}{l}\text { Cavia porcellus } 11 \beta \text {-hydroxysteroid dehydrogenase type } 1 \text { (Cp11ßHSD1) (diabetes target) } \\
\text { Enterobacter cloacae pentaerythritol tetranitrate reductase (EcPETNR) (antibacterial target) } \\
\text { Alicyclobacillus acidocardarius oxidosqualene cyclase (AaOSC) (cholesterol-lowering) } \\
\text { Human retinoic acid-related orphan receptor } \alpha(\mathrm{HsROR} \alpha) \text { (may regulate lipid metabolism) } \\
\text { Median docking energy }\end{array}$ \\
\hline $3 \beta$-Acetoxylup-20(29)-en-11 $\beta$-ol & 1uk1 & $\begin{array}{l}-121.9 \\
-50.4\end{array}$ & $\begin{array}{l}\text { Human poly(ADP-ribose) polymerase-1 (HsPARP-1) (anticancer target) } \\
\text { Median docking energy }\end{array}$ \\
\hline 4,23-Dihydroburic acid & $\begin{array}{l}1 \mathrm{~h} 22 \\
4 \mathrm{~b} 84 \\
1 \mathrm{jtx}\end{array}$ & $\begin{array}{l}-135.8 \\
-127.8 \\
-125.1 \\
+11.7\end{array}$ & $\begin{array}{l}\text { Torpedo californica acetylcholinesterase (TcAChE) (Alzheimer's target) } \\
\text { Murine acetylcholinesterase (MmAChE) (Alzheimer's target) } \\
\text { Staphylococcus aureus multidrug binding protein (SaQacR) } \\
\text { Median docking energy }\end{array}$ \\
\hline 6,7-Epoxy-9(11)-oleanen-3-ol & 4hai & $\begin{array}{l}-111.6 \\
-60.7\end{array}$ & $\begin{array}{l}\text { Human soluble epoxide hydrolase (HsEPHX2) (anti-inflammatory target) } \\
\text { Median docking energy }\end{array}$ \\
\hline 6,7-Epoxy-9(11)-oleanen-3-one & 1ry0 & $\begin{array}{l}-113.7 \\
-49.1\end{array}$ & $\begin{array}{l}\text { Human prostaglandin F synthase (HsPGFS) (hypertension target) } \\
\text { Median docking energy }\end{array}$ \\
\hline 9,11-Dehydro- $\beta$-boswellic acid & 1qvu & $\begin{array}{l}-114.3 \\
-60.8\end{array}$ & $\begin{array}{l}\text { Staphylococcus aureus multidrug binding protein (SaQacR) } \\
\text { Median docking energy }\end{array}$ \\
\hline Boscartene L & $313 \mathrm{~m}$ & $\begin{array}{l}-131.0 \\
-87.6\end{array}$ & $\begin{array}{l}\text { Human poly(ADP-ribose) polymerase-1 (HsPARP-1) (anticancer target) } \\
\text { Median docking energy }\end{array}$ \\
\hline Boscartene M & $313 m$ & $\begin{array}{l}-133.7 \\
-89.4\end{array}$ & $\begin{array}{l}\text { Human poly(ADP-ribose) polymerase-1 (HsPARP-1) (anticancer target) } \\
\text { Median docking energy }\end{array}$ \\
\hline Boscartene $\mathrm{N}$ & $\begin{array}{c}\text { 3ua9 } \\
3 \text { bt9 } \\
313 \mathrm{~m} \\
1 \mathrm{xl5}\end{array}$ & $\begin{array}{l}-157.2 \\
-136.7 \\
-133.3 \\
-125.2 \\
-95.1\end{array}$ & $\begin{array}{l}\text { Human tankyrase-2 (HsTANK2) }=\text { human poly(ADP-ribose) polymerase-5b (HsPARP-5b) (antitumor target) } \\
\text { Staphylococcus aureus multidrug binding protein (SaQacR) } \\
\text { Human poly(ADP-ribose) polymerase-1 (HsPARP-1) (anticancer target) } \\
\text { HIV-1 protease } \\
\text { Median docking energy }\end{array}$ \\
\hline Dammarenediol II & $\begin{array}{l}1 \mathrm{w} 6 \mathrm{k} \\
3 \mathrm{lz} 6 \\
1 \mathrm{~h} 36\end{array}$ & $\begin{array}{l}-135.1 \\
-134.6 \\
-129.2 \\
-72.1\end{array}$ & $\begin{array}{l}\text { Human oxidosqualene cyclase (HsOSC) (hypercholesterolemia target) } \\
\text { Cavia porcellus } 11 \beta \text {-hydroxysteroid dehydrogenase type } 1 \text { (Cp11ßHSD1) (diabetes target) } \\
\text { Alicyclobacillus acidocardarius oxidosqualene cyclase (AaOSC) (cholesterol-lowering) } \\
\text { Median docking energy }\end{array}$ \\
\hline
\end{tabular}


Table 6. Cont

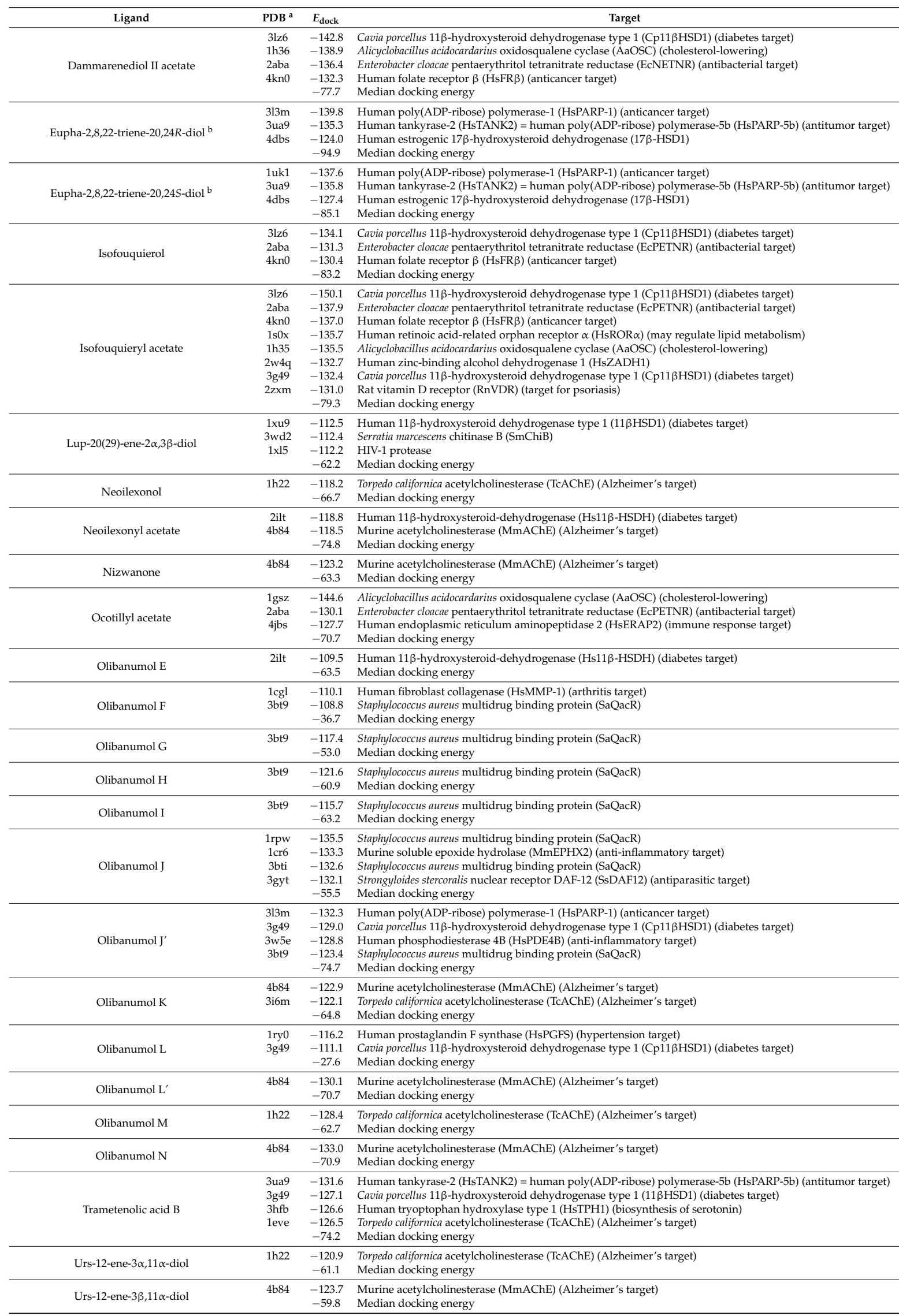


Table 6. Cont.

\begin{tabular}{|c|c|c|c|}
\hline Ligand & $\mathrm{PDB}^{\mathrm{a}}$ & $E_{\text {dock }}$ & Target \\
\hline$\alpha$-Boswellic acid & $3 g 49$ & $\begin{array}{l}-110.0 \\
-65.7\end{array}$ & $\begin{array}{l}\text { Cavia porcellus } 11 \beta \text {-hydroxysteroid dehydrogenase type } 1 \text { (11ßHSD1) (diabetes target) } \\
\text { Median docking energy }\end{array}$ \\
\hline$\alpha$-Elemolic acid & $\begin{array}{l}3 \text { ua9 } \\
1 \mathrm{c} 3 \mathrm{~s} \\
3 \mathrm{~g} 49\end{array}$ & $\begin{array}{l}-152.7 \\
-136.9 \\
-128.9 \\
-87.8\end{array}$ & $\begin{array}{l}\text { Human tankyrase-2 (HsTANK2) = human poly(ADP-ribose) polymerase-5b (HsPARP-5b) (antitumor target) } \\
\text { Aquifex aeolicus histone deacetylase (AaHDAC) (anticancer target) } \\
\text { Cavia porcellus } 11 \beta \text {-hydroxysteroid dehydrogenase type } 1 \text { (11ßHSD1) (diabetes target) } \\
\text { Median docking energy }\end{array}$ \\
\hline$\beta$-Boswellic acid & $3 \mathrm{i} 6 \mathrm{~m}$ & $\begin{array}{l}-118.1 \\
+20.7\end{array}$ & $\begin{array}{l}\text { Torpedo californica acetylcholinesterase (TcAChE) (Alzheimer's target) } \\
\text { Median docking energy }\end{array}$ \\
\hline$\beta$-Elemonic acid & $\begin{array}{l}\text { 3ua9 } \\
313 \mathrm{~m} \\
3 \mathrm{~g} 49\end{array}$ & $\begin{array}{l}-147.3 \\
-133.7 \\
-131.9 \\
-89.0\end{array}$ & $\begin{array}{l}\text { Human tankyrase-2 (HsTANK2) = human poly(ADP-ribose) polymerase-5b (HsPARP-5b) (antitumor target) } \\
\text { Human poly(ADP-ribose) polymerase- } 1 \text { (HsPARP-1) (anticancer target) } \\
\text { Cavia porcellus } 11 \beta \text {-hydroxysteroid dehydrogenase type } 1 \text { (11ßHSD1) (diabetes target) } \\
\text { Median docking energy }\end{array}$ \\
\hline$\delta$-Boswellic acid & $3 g 49$ & $\begin{array}{l}-106.7 \\
-60.7\end{array}$ & $\begin{array}{l}\text { Cavia porcellus } 11 \beta \text {-hydroxysteroid dehydrogenase type } 1 \text { (11ßHSD1) (diabetes target) } \\
\text { Median docking energy }\end{array}$ \\
\hline
\end{tabular}

The best overall triterpenoid ligand-protein target pairs were boscartene $\mathrm{N}$ with human tankyrase 2 (HsTANK2, PDB 3ua9), $E_{\text {dock }}=-157.2 \mathrm{~kJ} / \mathrm{mol} ; 3 \alpha$-hydroxytirucalla-7,24-dien-21-oic acid with HsTANK2, $E_{\text {dock }}=-154.3 \mathrm{~kJ} / \mathrm{mol}$; $\alpha$-elemolic acid with HsTANK2, $E_{\text {dock }}=$ -152.7 kJ/mol; 3-oxotirucalla-7,9(11),24-trien-21-oic acid with HsTANK2, $E_{\text {dock }}=-151.0 \mathrm{~kJ} / \mathrm{mol}$; $3 \alpha$-acetoxytirucalla-7,24-dien-21-oic acid with human glucokinase (PDB 4ixc), $E_{\text {dock }}=-150.4 \mathrm{~kJ} / \mathrm{mol}$; isofouquieryl acetate with Guinea pig (Cavia porcellus) 11 $\beta$-hydroxysteroid dehydrogenase type 1 (11ßHSD1, PDB 3lz6), $E_{\text {dock }}=-150.1 \mathrm{~kJ} / \mathrm{mol} ; 3 \beta$-acetoxy-20S,24S-dihydroxydammar-25-ene with Enterobacter cloacae pentaerythritol tetranitrate reductase (EcPETNR, PDB 2aba), $E_{\text {dock }}=-149.9 \mathrm{~kJ} / \mathrm{mol}$; and $3 \beta$-acetoxydammar-24-ene-16 $\beta, 20 R$-diol with Guinea pig $11 \beta$-hydroxysteroid dehydrogenase type 1 (Cp11ßHSD1, PDB 3lz6), $E_{\text {dock }}=-149.6 \mathrm{~kJ} / \mathrm{mol}$.

Frankincense oleo-gum resins have been used in traditional medicine to treat a variety of inflammatory conditions, including arthritis, colitis, and asthma [58,59]. Boswellic acids, including $\beta$-boswellic acid, 11-keto- $\beta$-boswellic acid, and acetyl-11-keto- $\beta$-boswellic acid, have been implicated in the anti-inflammatory properties of Boswellia resins; these triterpenoid components are involved in inhibition of 5-lipoxygenase (5-LOX), inducible nitric oxide synthase (iNOS), cyclooxygenase-1 (COX-1) and cyclooxygenase-2 (COX-2) [60].

In-silico screening of the Boswellia triterpenoids was carried out against molecular targets of inflammation, including human pancreatic secretory phospholipase A2 (HsPLA2), porcine pancreatic phospholipase A2 (SsPLA2), human phosphoinositide 3-kinase (HsPI3K), human interkeukin-1 receptor associated kinase 4 (HsIRAK4), human glutathione transferase omega 1 (HsGSTO1), human 5-lipoxygenase (Hs5-LOX), mouse inducible nitric oxide synthase (MmiNOS), ovine COX-1 (OaCOX-1), murine COX-2 (MmCOX-2), human fibroblast collagenase (matrix metalloproteinase-1, HsMMP-1), murine soluble epoxide hydrolase 2 (MmEPHX2), human endoplasmic reticulum aminopeptidase 2 (HsERAP2), human soluble epoxide hydrolase 2 (HsEPHX2), and human phosphodiesterase 4B (HsPDE4B). The docking energies of the triterpenoid ligands with inflammatory target proteins are shown in Table 7.

The Boswellia triterpenoids showed relatively weak docking to 5-LOX, iNOS, PI3K, IRAK4, or GSTO1, and no docking at all to either COX-1 or COX-2 (positive docking energies). However, several Boswellia triterpenoids showed relatively strong docking $\left(E_{\text {dock }}<-120 \mathrm{~kJ} / \mathrm{mol}\right)$ to human endoplasmic reticulum aminopeptidase 2 (HsERAP2), including 3 $\beta$-acetoxy-20S,24Sdihydroxydammar-25-ene, $3 \beta$-acetoxydammar-24-ene-16 $\beta, 20 R$-diol, isofouquieryl acetate, ocotillyl acetate, olibanumol J, and olibanumol J'. There is a significant association of ERAP2 with psoriatic arthritis [61], and notably, Boswellia triterpenoids have shown promise for the treatment of psoriasis [62]. Similarly, inhibitors of phosphodiesterase 4B have shown promise in the treatment of psoriasis and atopic dermatitis [63], and isofouquierol and olibanumol J' showed good docking properties with HsPDE4B with docking energies of -128.3 and $-128.8 \mathrm{~kJ} / \mathrm{mol}$, respectively. 
The only other strong docking observed was olibanumol J with murine soluble epoxide hydrolase 2 (MmEPHX2), 3 $\alpha$-acetoxytirucalla-7,24-dien-21-oic acid with human matrix metalloproteinase-1 (HsMMP-1), (20S)-3,7-dioxotirucalla-8,24-dien-21-oic acid with porcine pancreatic phospholipase A2 (SsPLA2), and 3 $\beta$-acetoxy-20S,24-dihydroxydammar-25-ene with human pancreatic secretory phospholipase A2 (HsPLA2). The targeting of matrix metalloproteinase-1 (fibroblast collagenase) is noteworthy; $B$. serrata extract has shown clinical efficacy as a treatment for osteoarthritis of the knee [64].

Note that $\beta$-boswellic acid, 11-keto- $\beta$-boswellic acid, and 3-acetyl-11-keto- $\beta$-boswellic acid had relatively weak docking with inflammation-relevant protein targets. It may be that these Boswellia triterpenoids, rather than inhibiting particular enzyme targets, are inhibiting the secretion of pro-inflammatory cytokines such as tumor necrosis factor $\alpha$ (TNF $\alpha)$, interleukin 1 (IL-1), IL-6, IL-12, IL-18, or interferon $\gamma($ IFN- $\gamma)$ [65].

Olibanumols G, H, I, and J all showed selective docking to $S$. aureus multidrug binding protein (SaQacR). The olibanumols occupy the binding site of SaQacR, same site as the co-crystallized ligand in PDB 3bti (Figure 10). The site is made up of aromatic amino acids Trp61, Tyr93, and Tyr123, forming a hydrophobic pocket. The triterpenoid ligand olibanumol J also has a hydrogen-bonding interaction between $\mathrm{C}(3)-\mathrm{OH}$ of the ligand and the amide $\mathrm{C}=\mathrm{O}$ of Ala153. Other key interacting amino acids in the binding site are Ser86, Glu90, and Asn157. In addition to the olibanumols, six additional triterpenoids also showed selective docking to SaQacR, 3-acetoxy-12,20(29)-lupadien-24-oic acid, lupeolic acid, 3-oxotirucalla-7,9(11),24-trien-21-oic acid, 4,23-dihydroburic acid, 9,11-dehydro- $\beta$-boswellic acid, and boscartene $\mathrm{N}$.
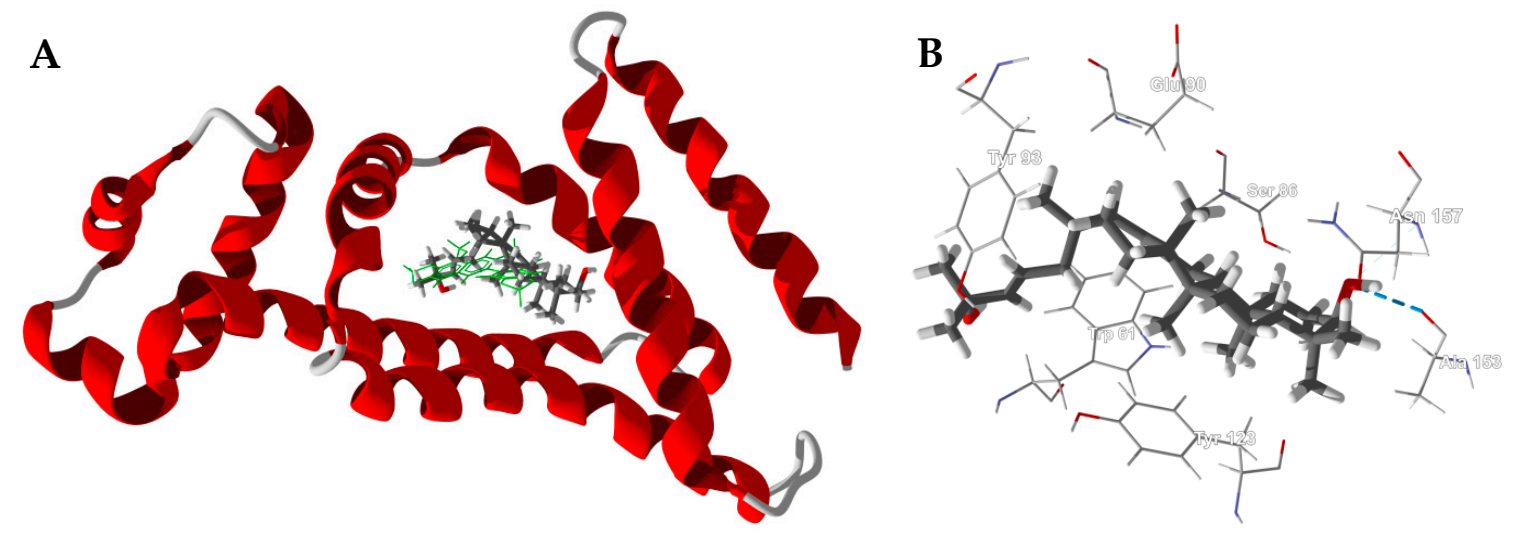

Figure 10. Lowest-energy docking pose of olibanumol J with Staphylococcus aureus multidrug binding protein (SaQacR, PDB 3bti). (A): Ribbon structure of SaQacR showing olibanumol J ( $E_{\text {dock }}$ $=-132.6 \mathrm{~kJ} / \mathrm{mol})$ in the active site. The co-crystallized ligand, berberine $\left(E_{\text {dock }}=-113.8 \mathrm{~kJ} / \mathrm{mol}\right)$, is shown as a green wire structure. (B): Key interactions of olibanumol $\mathrm{J}$ in the active site of SaQacR. The hydrogen-bond is indicated by a blue dashed line.

Another antibacterial target protein that showed good docking properties was Enterobacter cloacae pentaerythritol tetranitrate reductase (EcPETNR) with seven Boswellia dammarane triterpenoids

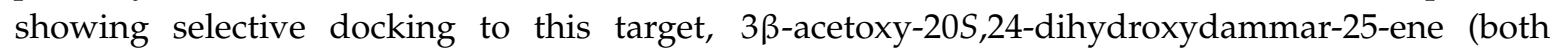
diastereomers), 3 $\beta$-acetoxydammar-24-ene-16 $\beta, 20 R$-diol, dammarenediol II acetate, isofouquierol, isofouquieryl acetate, and ocotillyl acetate. These dammarane triterpenoids occupy the active site of EcPETNR, near to the riboflavin monophosphate redox cofactor, with very similar docked poses (Figure 11). Key intermolecular contacts are hydrogen bonding of the C(3) acetoxygroup with Arg142, hydrogen-bonding of $\mathrm{C}(20)-\mathrm{OH}$ with the riboflavin monophosphate cofactor and His184 (Figure 11B). In the case of $3 \beta$-acetoxy-20S,24S-dihydroxydammar-25-ene, there is also a hydrogen-bond between the $\mathrm{C}(24)-\mathrm{OH}$ group and Asp274. 

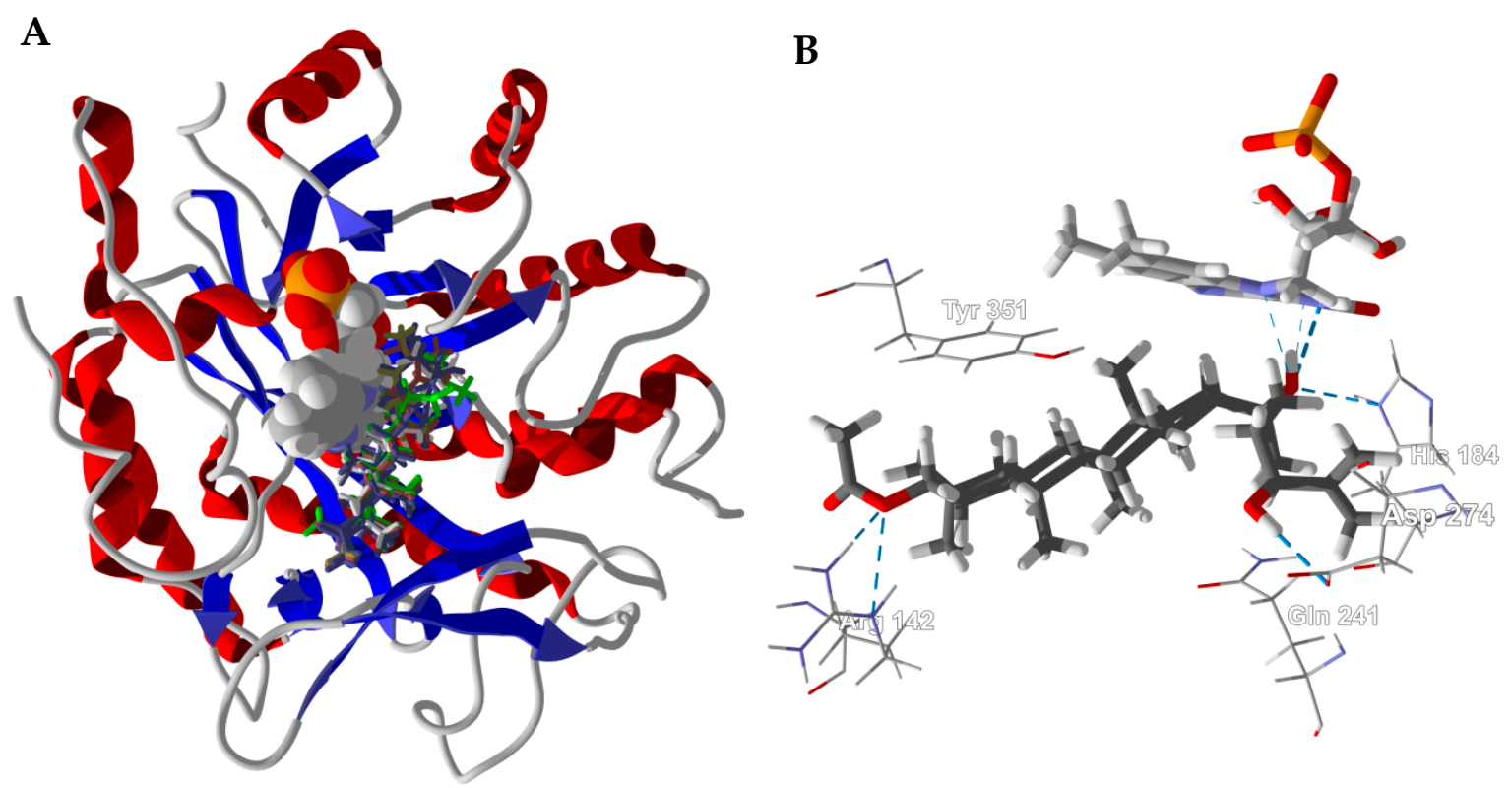

Figure 11. Enterobacter cloacae pentaerythritol tetranitrate reductase (EcPETNR, PDB 2aba). (A): Ribbon structure of EcPETNR with docked dammarane triterpenoids (stick figures). The riboflavin monophosphate cofactor is shown as a space-filling model. (B): Lowest-energy docked pose of $3 \beta$-acetoxy-20S,24S-dihydroxydammar-25-ene. Hydrogen-bonding interactions are indicated with blue dashed lines.

Drugs that reversibly inhibit acetylcholinesterase are currently being explored to treat Alzheimer's disease [66], and Torpedo californica and murine acetylcholinesterases have been used as model enzyme targets for anticholinesterase inhibition [67]. $\beta$-Boswellic acid and its derivatives (11-keto- $\beta$-boswellic acid, 11-ethoxy- $\beta$-boswellic acid, 3-acetyl- $\beta$-boswellic acid, and 3-acetyl-11-keto- $\beta$-boswellic acid) showed selective docking to Torpedo californica acetylcholinesterase (TcAChE, PDB 3i6m). Interestingly, increasing oxygenation resulted in more exothermic docking energies $(-118.1,-120.8,-124.6,-128.3$, and $-129.7 \mathrm{~kJ} / \mathrm{mol}$, respectively). These $\beta$-boswellic acid derivatives all adopt the same lowest-energy poses in the active site of the enzyme (Figure 12). It is tempting to suggest that the ordering of docking energies is due to increasing hydrogen-bonding of the more oxygenated ligands. However, the only hydrogen bonding seen is with the $\mathrm{C}(3)$-substituent of the ligand (either -OH or -OAc) with Tyr121 (see Figure 10B. Note that the active site of the acetylcholinesterase is surrounded by aromatic amino acids (Trp84, Tyr334, Tyr121, Phe330, Phe331, and Trp279). The more important interactions, therefore, are van der Waals hydrophobic interactions between the ligand and the aromatic amino acids. The trend in docking energies for these $\beta$-boswellic acid derivatives is likely due to the increased number of heavy atoms and increasing molecular weight. Olibanumols $\mathrm{K}, \mathrm{L}^{\prime}, \mathrm{M}$, and $\mathrm{N}$ also showed selective docking to acetylcholinesterase proteins. The strongest-docking triterpenoid ligands to TcAChE were 4,23-dihydroburic acid ( $\left.E_{\text {dock }}=-135.8 \mathrm{~kJ} / \mathrm{mol}\right)$ and 3-acetoxy-5,12-ursadien-24-oic acid $\left(E_{\text {dock }}=-131.7 \mathrm{~kJ} / \mathrm{mol}\right) ;$ olibanumol $\mathrm{N}$ docked strongly with $\operatorname{MmAChE}\left(E_{\text {dock }}=-133.0 \mathrm{~kJ} / \mathrm{mol}\right)$. The excellent docking properties of Boswellia triterpenoid ligands to acetylcholinesterase supports the clinical use of frankincense to treat Alzeimer's disease [41]. 
Table 7. MolDock docking energies $(\mathrm{kJ} / \mathrm{mol})$ of Boswellia triterpenoid ligands with inflammation-relevant protein targets.

\begin{tabular}{|c|c|c|c|c|c|c|c|c|c|c|c|c|}
\hline \multirow{2}{*}{ Ligand } & \multirow{2}{*}{$\begin{array}{c}\text { MmEPHX2 } \\
1 \mathrm{cr} 6\end{array}$} & \multirow{2}{*}{$\begin{array}{c}\text { HsEPHX2 } \\
\text { 4hai }\end{array}$} & \multirow{2}{*}{$\begin{array}{c}\text { HsMMP-1 } \\
1 \mathrm{cgl}\end{array}$} & \multirow{2}{*}{$\begin{array}{c}\text { SsPLA2 } \\
2 \mathrm{~b} 03\end{array}$} & \multirow{2}{*}{$\begin{array}{c}\text { HsPLA2 } \\
1 \mathrm{j} 1 \mathrm{a}\end{array}$} & \multirow{2}{*}{$\begin{array}{c}\text { Hs5-LOX } \\
3 \mathrm{v} 99\end{array}$} & \multirow{2}{*}{$\begin{array}{c}\text { Mm iNOS } \\
1 \mathrm{~m} 8 \mathrm{~d}\end{array}$} & \multirow{2}{*}{$\begin{array}{c}\text { HsPI3K } \gamma \\
2 \mathrm{a} 5 \mathrm{u}\end{array}$} & \multirow{2}{*}{$\begin{array}{c}\text { HsIRAK4 } \\
5 \text { t1s }\end{array}$} & \multirow{2}{*}{$\begin{array}{c}\text { HsERAP2 } \\
\text { 4jbs }\end{array}$} & \multicolumn{2}{|c|}{ HsGSTO1 HsPDE4B } \\
\hline & & & & & & & & & & & $5 v 3 q$ & $3 w 5 e$ \\
\hline (20S)-3,7-Dioxotirucalla-8,24-dien-21-oic acid & -113.3 & -114.1 & -121.8 & -127.4 & -106.9 & -103.1 & -88.0 & -87.7 & -112.7 & -107.3 & -106.0 & -114.0 \\
\hline 11-Ethoxy- $\beta$-boswellic acid & -80.3 & -96.3 & -107.9 & -100.9 & -87.3 & -85.8 & -71.7 & -82.5 & -99.7 & -104.5 & -66.8 & -101.5 \\
\hline 11-Keto- $\beta$-boswellic acid & -75.7 & -91.8 & -100.7 & -94.9 & -85.3 & -83.3 & -64.2 & -77.2 & -89.7 & -99.4 & -70.7 & 2.8 \\
\hline 12-Ursen-3,11-dione & -73.9 & -88.8 & -102.0 & -102.4 & -71.2 & -75.8 & -63.0 & -74.9 & -82.0 & -98.6 & -71.4 & -99.9 \\
\hline 12-Ursen-3,24-diol & -81.9 & -84.5 & -105.5 & -88.7 & -93.7 & -77.4 & -60.4 & -76.9 & -89.8 & -96.4 & -87.8 & -101.1 \\
\hline 2,3-Dihydroxy-12-ursen-24-oic acid & -78.8 & -83.9 & -98.9 & -100.0 & -91.1 & -81.7 & -30.0 & -78.6 & -91.7 & -96.5 & -74.8 & -102.4 \\
\hline 20,22-Epoxytirucall-24-en-3-one & -98.2 & -102.5 & -113.1 & -111.0 & -95.7 & -90.2 & -89.9 & -82.5 & -94.7 & -105.1 & -80.9 & -99.3 \\
\hline 24-Nor-3,12-ursadien-11-one & -84.1 & -89.6 & -99.9 & -103.4 & -95.6 & -77.5 & -71.8 & -75.1 & -64.1 & -91.7 & -50.1 & -83.4 \\
\hline 24-Nor-3,9(11),12-oleanatriene & -83.4 & -94.7 & -99.5 & -99.9 & -93.3 & -70.8 & -61.0 & -75.2 & -59.9 & -95.3 & -47.3 & -90.8 \\
\hline 24-Nor-3,9(11),12-ursatriene & -83.3 & -89.4 & -100.6 & -99.3 & -85.5 & -81.4 & -65.0 & -75.3 & -77.0 & -86.3 & -62.2 & -91.2 \\
\hline 3-Acetoxy-12,20(29)-lupadien-24-oic acid & -77.8 & -85.2 & -115.4 & -87.5 & -82.7 & -83.7 & -68.4 & -93.6 & -59.1 & -105.0 & -78.9 & -97.8 \\
\hline 3-Acetoxy-20(29)-lupen-24-oic acid (=3-Acetyl lupeolic acid) & -84.1 & -83.5 & -117.5 & -86.7 & -87.1 & -82.7 & -71.8 & -92.9 & -79.7 & -104.5 & -79.0 & -92.8 \\
\hline $3 \beta$-Acetoxy-20S,24R-dihydroxydammar-25-ene & -109.7 & -109.3 & -124.7 & -118.5 & -120.3 & -100.8 & -96.7 & -94.4 & -106.4 & -119.1 & -85.8 & -116.3 \\
\hline $3 \beta$-Acetoxy-20S,24S-dihydroxydammar-25-ene & -106.2 & -109.2 & -121.7 & -115.6 & -122.0 & -100.3 & -81.5 & -93.9 & -109.5 & -126.1 & -76.5 & -111.0 \\
\hline 3-Acetoxy-5,12-ursadien-24-oic acid & -92.6 & -78.1 & -121.1 & -97.5 & -81.7 & -81.0 & -73.3 & -83.6 & -70.4 & -105.0 & -70.2 & -47.3 \\
\hline 3-Acetyl-11-keto- $\beta$-boswellic acid & -87.3 & -75.6 & -107.6 & -102.4 & -74.0 & -84.9 & -67.7 & -79.7 & -71.9 & -93.3 & -71.6 & -49.2 \\
\hline 3-Acetyl-11 $\alpha$-methoxy- $\beta$-boswellic_acid & -86.7 & -91.1 & -109.3 & -91.0 & -75.4 & -87.3 & -76.1 & -79.5 & -90.0 & -101.9 & -69.5 & -52.0 \\
\hline 3-Acetyl-9,11-dehydro- $\beta$-boswellic_acid & -90.4 & -80.3 & -120.6 & -98.5 & -94.8 & -82.7 & -74.4 & -82.7 & -61.1 & -103.7 & -84.3 & -50.3 \\
\hline 3-Acetyl- $\alpha$-boswellic acid & -79.0 & -82.4 & -109.7 & -112.7 & -97.2 & -82.0 & -70.5 & -83.0 & -83.8 & -99.7 & -72.7 & -91.4 \\
\hline 3-Acetyl- $\beta$-boswellic acid & -91.5 & -83.1 & -119.8 & -99.4 & -96.2 & -85.1 & -69.0 & -79.4 & -70.8 & -90.2 & -80.6 & -91.8 \\
\hline 3-Hydroxy-20(29)-lupen-24-oic acid (=Lupeolic acid) & -103.4 & -105.0 & -106.6 & -82.6 & -76.6 & -79.2 & -72.6 & -81.8 & -76.0 & -103.4 & -69.5 & -87.3 \\
\hline 3-Oxotirucalla-7, $9(11), 24$-trien-21-oic acid & -113.1 & -113.3 & -123.3 & -116.9 & -113.5 & -100.5 & -86.3 & -92.1 & -103.6 & -108.8 & -99.8 & -113.2 \\
\hline $3 \beta$-Hydroxytirucalla-8,24-dien-21-oic acid & -110.8 & -112.1 & -118.6 & -123.4 & -106.5 & -103.3 & -97.3 & -80.7 & -107.8 & -109.4 & -94.6 & -111.9 \\
\hline $3 \alpha$-Acetoxytirucalla-7,24-dien-21-oic acid & -115.5 & -113.3 & -129.9 & -109.8 & -116.2 & -91.2 & -95.4 & -95.3 & -109.7 & -106.1 & -91.4 & -104.9 \\
\hline $3 \alpha$-Hydroxytirucalla-7,24-dien-21-oic acid & -110.8 & -115.7 & -115.4 & -117.2 & -110.1 & -105.7 & -84.1 & -86.9 & -102.8 & -108.6 & -82.9 & -109.8 \\
\hline $3 \beta$-Acetoxydammar-24-ene- $16 \beta, 20 R$-diol & -102.8 & -110.3 & -125.7 & -111.2 & -109.3 & -97.7 & -97.0 & -90.7 & -107.9 & -125.2 & -79.8 & -115.2 \\
\hline $3 \beta$-Acetoxylup-20(29)-en-11 $\beta$-ol & -94.6 & -92.9 & -109.8 & -105.6 & -90.8 & -86.1 & -87.1 & -80.9 & -93.2 & -108.2 & -74.5 & -41.2 \\
\hline 4,23-Dihydroburic acid & -101.2 & -101.6 & -109.8 & -120.9 & -92.0 & -88.3 & -72.0 & -84.3 & -102.9 & -110.2 & -85.3 & -107.7 \\
\hline 6,7-Epoxy-9(11)-oleanen-3-ol & -53.0 & -111.6 & -100.2 & -106.3 & -89.8 & -79.6 & -64.5 & -67.7 & -66.2 & -94.9 & -68.6 & -87.2 \\
\hline 6,7-Epoxy-9(11)-oleanen-3-one & -66.0 & -100.9 & -105.0 & -107.8 & -93.3 & -75.1 & -68.5 & -70.3 & -40.3 & -100.6 & -66.1 & -106.2 \\
\hline 9,11-Dehydro- $\beta$-boswellic acid & -75.8 & -85.7 & -109.8 & -96.8 & -93.1 & -79.8 & -27.4 & -73.6 & -89.5 & -91.2 & -83.4 & -62.6 \\
\hline Boscartene L & -83.2 & -110.2 & -104.4 & -115.7 & -77.4 & -100.1 & -81.6 & -82.0 & -100.0 & -108.6 & -62.6 & -97.7 \\
\hline Boscartene M & -73.8 & -110.8 & -114.0 & -107.0 & -96.7 & -102.9 & -86.8 & -83.4 & -76.8 & -110.4 & -83.5 & -91.5 \\
\hline Boscartene N & -110.2 & -113.7 & -116.6 & -126.2 & -106.6 & -92.9 & -85.8 & -87.4 & -109.6 & -111.8 & -100.1 & -118.6 \\
\hline Dammarenediol II & -114.1 & -112.3 & -126.2 & -103.7 & -110.8 & -95.8 & -77.3 & -87.2 & -110.3 & -108.4 & -101.4 & -120.5 \\
\hline Dammarenediol II acetate & -109.5 & -109.5 & -113.4 & -101.8 & -115.7 & -105.2 & -92.1 & -97.4 & -115.2 & -107.2 & -77.7 & -104.9 \\
\hline Eupha-2,8,22-triene-20,24R-diol & -111.9 & -106.1 & -112.9 & -121.3 & -98.2 & -97.9 & -80.5 & -85.9 & -101.0 & -106.4 & -92.8 & -104.5 \\
\hline Eupha-2,8,22-triene-20,24S-diol & -117.2 & -104.4 & -113.1 & -115.5 & -100.1 & -97.8 & -82.6 & -87.3 & -99.4 & -103.0 & -94.1 & -105.8 \\
\hline Isofouquierol & -116.4 & -103.7 & -118.4 & -113.5 & -114.9 & -104.0 & -96.4 & -93.2 & -110.4 & -114.1 & -96.8 & -128.3 \\
\hline Isofouquieryl acetate & -107.6 & -119.6 & -123.5 & -122.4 & -115.8 & -96.8 & -103.7 & -86.4 & -113.4 & -124.4 & -85.2 & -106.6 \\
\hline Lup-20(29)-ene-2 $\alpha, 3 \beta$-diol & -101.4 & -98.8 & -106.0 & -95.5 & -83.0 & -71.4 & -87.9 & -75.4 & -89.8 & -107.6 & -73.2 & -73.6 \\
\hline Neoilexonol & -73.0 & -87.9 & -101.1 & -104.8 & -71.4 & -74.7 & -62.8 & -69.5 & -52.3 & -92.8 & -73.9 & -98.0 \\
\hline Neoilexonyl acetate & -86.0 & -86.7 & -108.2 & -109.9 & -83.8 & -79.4 & -68.2 & -74.3 & -87.5 & -95.5 & -69.4 & -31.7 \\
\hline Nizwanone & -81.2 & -89.7 & -108.6 & -89.5 & -95.3 & -78.5 & -60.5 & -70.1 & -88.3 & -98.1 & -90.9 & -106.3 \\
\hline Ocotillyl acetate & -94.4 & -96.1 & -121.5 & -105.5 & -107.2 & -96.7 & -72.8 & -84.5 & -108.2 & -127.7 & -77.5 & -97.2 \\
\hline
\end{tabular}


Table 7. Cont.

\begin{tabular}{|c|c|c|c|c|c|c|c|c|c|c|c|c|}
\hline \multirow{2}{*}{ Ligand } & \multirow{2}{*}{$\begin{array}{c}\text { MmEPHX2 } \\
1 \mathrm{cr} 6\end{array}$} & \multirow{2}{*}{$\begin{array}{c}\text { HsEPHX2 } \\
\text { 4hai }\end{array}$} & \multirow{2}{*}{$\begin{array}{c}\text { HsMMP-1 } \\
1 \mathrm{cgl}\end{array}$} & \multirow{2}{*}{$\begin{array}{c}\text { SsPLA2 } \\
2 \mathrm{~b} 03\end{array}$} & \multirow{2}{*}{$\begin{array}{c}\text { HsPLA2 } \\
1 \mathrm{j} 1 \mathrm{a}\end{array}$} & \multirow{2}{*}{$\begin{array}{c}\text { Hs5-LOX } \\
3 \mathrm{v} 99\end{array}$} & \multirow{2}{*}{$\begin{array}{c}\text { Mm iNOS } \\
1 \mathrm{~m} 8 \mathrm{~d}\end{array}$} & \multirow{2}{*}{$\begin{array}{c}\text { HsPI3K } \gamma \\
2 a 5 u\end{array}$} & \multirow{2}{*}{$\begin{array}{c}\text { HsIRAK4 } \\
5 \text { t1s }\end{array}$} & \multirow{2}{*}{$\begin{array}{c}\text { HsERAP2 } \\
\text { 4jbs }\end{array}$} & \multicolumn{2}{|c|}{ HsGSTO1 HsPDE4B } \\
\hline & & & & & & & & & & & $5 \mathrm{v} 3 \mathrm{q}$ & $3 w 5 e$ \\
\hline Olibanumol E & -81.7 & -82.4 & -101.7 & -98.7 & -91.8 & -82.2 & -60.6 & -79.4 & -92.4 & -97.9 & -49.2 & -99.2 \\
\hline Olibanumol F & -85.7 & -108.9 & -110.1 & -86.1 & -79.7 & -87.6 & -65.9 & -86.4 & -80.4 & -95.0 & -77.3 & -46.1 \\
\hline Olibanumol G & -81.5 & -95.3 & -99.3 & -82.4 & -70.4 & -80.0 & -61.0 & -77.9 & -80.8 & -93.2 & -54.0 & -72.7 \\
\hline Olibanumol H & -101.1 & -113.9 & -107.7 & -102.3 & -86.8 & -82.6 & -78.1 & -88.4 & -94.2 & -103.8 & -74.1 & -55.0 \\
\hline Olibanumol I & -96.2 & -97.4 & -101.5 & -93.4 & -70.6 & -81.9 & -75.5 & -78.2 & -88.8 & -96.9 & -71.6 & -79.2 \\
\hline Olibanumol J & -133.3 & -119.3 & -114.2 & -112.5 & -117.6 & -106.1 & -93.8 & -88.4 & -108.3 & -123.8 & -99.3 & -112.3 \\
\hline Olibanumol J' & -108.2 & -119.2 & -112.7 & -112.3 & -118.8 & -107.7 & -84.4 & -84.3 & -109.2 & -124.4 & -84.6 & -128.8 \\
\hline Olibanumol K & -88.8 & -77.8 & -110.3 & -90.5 & -94.9 & -77.0 & -64.9 & -79.8 & -76.2 & -89.9 & -78.8 & -82.4 \\
\hline Olibanumol L & -78.1 & -80.8 & -109.6 & -91.7 & -98.1 & -81.3 & -67.6 & -73.8 & -82.4 & -97.3 & -64.1 & -108.1 \\
\hline Olibanumol L' & -85.0 & -74.1 & -111.4 & -97.1 & -83.9 & -84.7 & -67.6 & -77.4 & -72.7 & -92.4 & -70.0 & -37.9 \\
\hline Olibanumol M & -77.5 & -89.2 & -100.1 & -95.5 & -57.5 & -83.9 & -69.2 & -77.1 & -96.5 & -93.1 & -63.9 & -100.0 \\
\hline Olibanumol N & -85.0 & -76.5 & -103.3 & -84.5 & -70.8 & -86.3 & -73.6 & -79.7 & -87.9 & -96.8 & -70.4 & -50.1 \\
\hline Trametenolic acid B & -106.3 & -107.3 & -106.9 & -107.3 & -107.9 & -99.7 & -92.6 & -84.0 & -107.6 & -115.0 & -92.9 & -111.6 \\
\hline Urs-12-ene- $3 \alpha, 11 \alpha$-diol & -77.8 & -78.6 & -104.3 & -94.2 & -85.2 & -84.4 & -68.3 & -77.7 & -92.2 & -90.9 & -64.6 & -100.1 \\
\hline Urs-12-ene-3 $3,11 \alpha$-diol & -79.4 & -74.8 & -101.3 & -108.0 & -71.2 & -76.9 & -67.3 & -69.9 & -70.9 & -93.8 & -61.8 & -114.1 \\
\hline$\alpha$-Boswellic acid & -77.9 & -87.8 & -103.7 & -100.2 & -95.0 & -80.7 & -64.4 & -79.4 & -85.7 & -94.8 & -62.5 & -62.0 \\
\hline$\alpha$-Elemolic acid & -106.5 & -110.5 & -113.9 & -124.4 & -104.1 & -99.7 & -107.1 & -84.0 & -108.7 & -111.1 & -97.3 & -110.3 \\
\hline$\beta$-Boswellic acid & -78.0 & -87.8 & -108.9 & -94.2 & -90.0 & -82.5 & -7.8 & -76.7 & -91.1 & -94.4 & -85.2 & -95.5 \\
\hline$\beta$-Elemonic acid & -112.2 & -113.8 & -110.5 & -123.3 & -109.6 & -100.4 & -92.4 & -86.3 & -106.6 & -107.1 & -108.0 & -112.6 \\
\hline$\beta$-Elemonic acid & -110.0 & -114.6 & -120.2 & -120.4 & -106.3 & -99.8 & -98.8 & -83.5 & -109.2 & -109.0 & -103.6 & -116.2 \\
\hline$\delta$-Boswellic acid & -76.4 & -90.4 & -101.3 & -89.6 & -82.5 & -74.7 & -69.2 & -80.7 & -87.2 & -96.4 & -64.4 & -76.4 \\
\hline
\end{tabular}


A

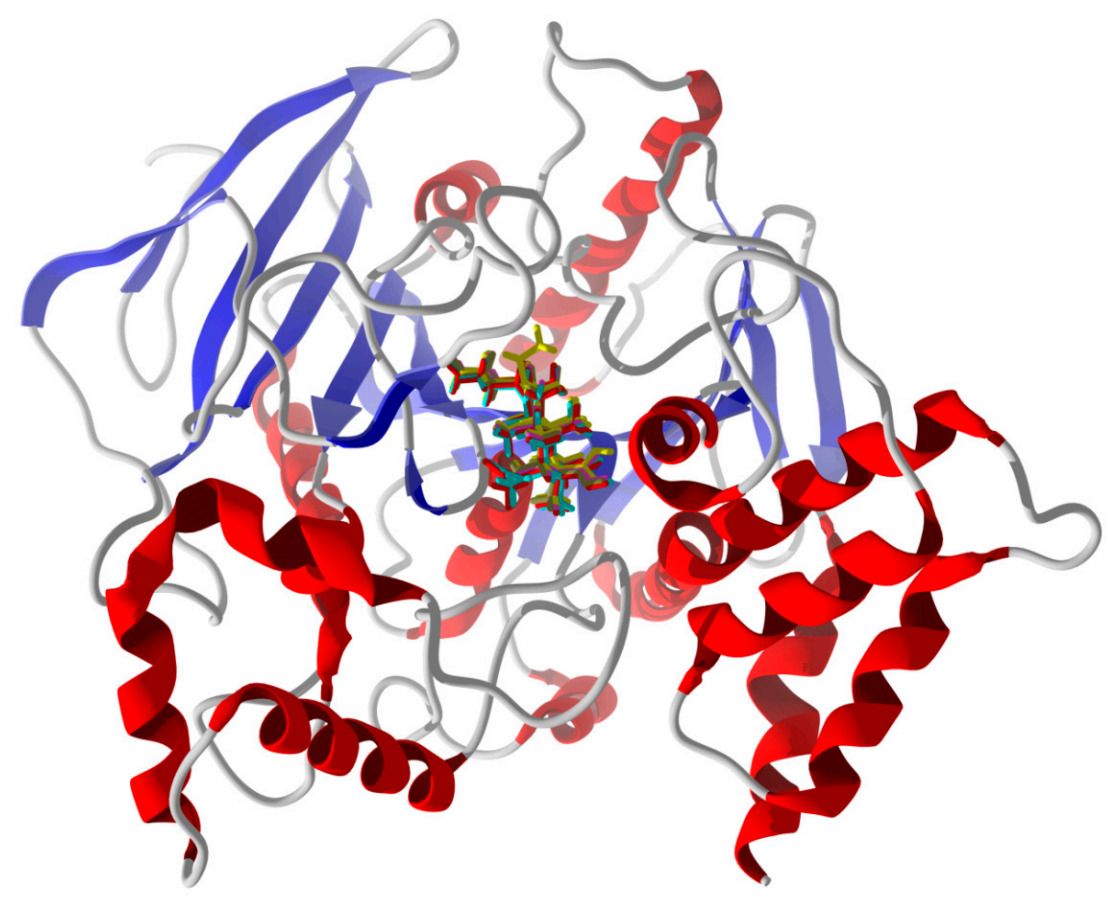

B

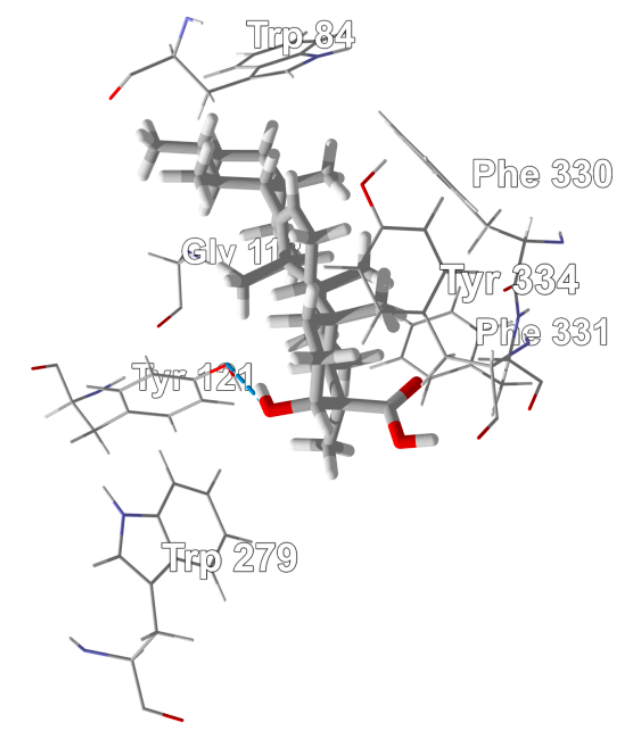

C

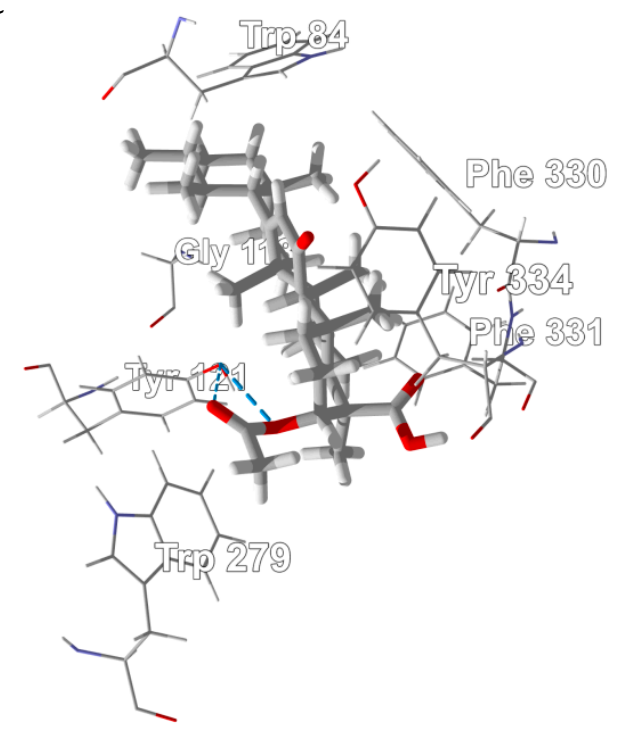

Figure 12. Lowest-energy docked poses of $\beta$-boswellic acid derivatives with Torpedo californica acetylcholinesterase (TcAChE, PDB 3i6m). (A): Ribbon structure with docked ligands, $\beta$-boswellic acid (brown), 11-keto- $\beta$-boswellic acid (magenta), 11-ethoxy- $\beta$-boswellic acid (yellow), 3-acetyl- $\beta$-boswellic acid (red), and 3-acetyl-11-keto- $\beta$-boswellic acid (aqua). (B): Molecular environment of docked $\beta$-boswellic acid in the active site of TcAChE. (C): Molecular environment of docked 3 -acetyl-11-keto- $\beta$-boswellic acid in the active site of TcAChE.

Several protein targets related to cancer were targeted by Boswellia triterpenoids, including poly(ADP-ribose) polymerase-1 (PARP-1), tankyrase-1 (TANK1), tankyrase-2 (TANK2), folate receptor $\beta$ (FR $\beta$ ), and histone deacetylase (HDAC). Poly(ADP-ribose) polymerase-1 (PARP-1) is an important enzyme for the repair of single-strand DNA breaks, and inhibition of PARP-1 can cause multiple double strands DNA breaks to occur, leading to cell death [68]. Several types of cancers are more dependent on PARP-1 than normal cells, so PARP-1 has become an attractive target for cancer 
chemotherapy $[69,70]$. At least 15 Boswellia triterpenoids showed selective docking to PARP-1 (see Table 6). The strongest-docking ligands for human PARP-1 were (20S)-3,7-dioxotirucalla-8,24-dien-21-oic $\operatorname{acid}\left(E_{\text {dock }}=-141.8 \mathrm{~kJ} / \mathrm{mol}\right)$ and eupha-2,8,22-triene-20,24R-diol $\left(E_{\text {dock }}=-139.8 \mathrm{~kJ} / \mathrm{mol}\right)$.

Folate receptors are overexpressed in cancer cells, presumably due to the increased requirement of cancer cells for folic acid needed in cell proliferation [71] and folate receptor- $\beta$ is overexpressed in lung, liver, skin, and soft tissue tumors, as well as associated stromal cells. Folate receptors, therefore, show promise as chemotherapeutic targets for cancer and other human pathologies [72]. Three of the Boswellia triterpenoids in this study showed excellent docking properties to human folate receptor $\beta$ (HsFR $\beta)$, namely dammarenediol II acetate, isofouquierol, and isofouquieryl acetate, with docking energies of $-132.3,-130.4$, and $-137.0 \mathrm{~kJ} / \mathrm{mol}$, respectively.

Histone deacetylases (HDAC) are enzymes that remove acetyl groups from lysine residues of histones, which allow the histones to envelope DNA more tightly. Thus, HDACs can affect cell growth and differentiation and cell death $[73,74]$. Histone deacetylase has been recognized as a promising target for cancer chemotherapy [75,76]. Reverse docking of Boswellia triterpenoids has revealed $\alpha$-elemolic acid to preferentially dock to Aquifex aeolicus histone deacetylase (AaHDAC).

Frankincense-containing formulations had been used in ancient Greece for treating various malignant tumors [77]. Frankincense has been used in the Indian traditional medicine (Ayurveda) and in Traditional Chinese Medicine (TCM) as a treatment for proliferative diseases [78]. In addition, extracts of frankincense oleo-gum resins have shown in-vitro cytotoxic activity on several human tumor-derived cell lines [58,79-81], and these activities have been attributed to boswellic acids [82]. Interestingly, although $\beta$-boswellic acid [83] and 3-acetyl-11-keto- $\beta$-boswellic acid [84] have shown antineoplastic activities, this reverse-docking study did not reveal particularly notable docking properties to cancer-relevant protein targets. It may be that the boswellic acids and derivatives are targeting inflammatory pathways $[85,86]$ or multiple targets as their mechanisms of antineoplastic activities [82,84].

Several Boswellia triterpenoids showed good docking properties to 11ß-hydroxysteroid dehydrogenase type 1 (11ßHSD1). For example, the dammarane triterpenoids $3 \beta$-acetoxy20S,24-dihydroxydammar-25-ene, 3 3 -acetoxydammar-24-ene-16 $\beta, 20 R$-diol, dammarenediol II, dammarenediol II acetate, isofouquierol, and isofouquieryl acetate showed excellent docking energies with Cavia porcellus 11ß-hydroxysteroid dehydrogenase type 1 (Cp11ßHSD1, PDB 3lz6). These dammarane triterpenoids all occupy the same position in the active site of the enzyme, blocking access to the NADPH cofactor (Figure 13). The docked dammaranes are sandwiched between the NADPH cofactor and hydrophobic amino acids Tyr152, Tyr98, Tyr158, Leu192, and Tyr206 (Figure 13B). There are also close contacts, but no apparent hydrogen-bonds, with Thr197 and Asn99. $11 \beta$-Hydroxysteroid dehydrogenase type 1 mediates the interconversion of cortisone and cortisol and overexpression of $11 \beta$ HSD1 can lead to metabolic disease, characterized by visceral obesity, hyperlipidemia, hypertension, glucose intolerance, insulin resistance, and type II diabetes [87,88]. Thus, inhibition of 11ßHSD1 may serve as a treatment option for metabolic syndrome and type II diabetes $[89,90]$.

Boswellia serrata is used traditionally by diabetic patients in Iran, and B. serrata supplementation has shown clinical benefit in blood lipid and glucose levels in type II diabetic patients [91,92]. Furthermore, B. serrata resin extract has been shown to prevent increase in blood glucose levels in streptozotocin-induced diabetic mice [93]. Similarly, B. glabra extracts have shown hypoglycemic effects in alloxan-induced diabetic rats [94]. The selective targeting of Guinea pig 11ßHSD1 and human $11 \beta H S D 1$ by Boswellia triterpenoids is consistent with the traditional use and anti-diabetic activities of Boswellia oleo-gum resin.

Oxidosqualene cyclases (OSCs) are enzymes that catalyze the cyclization of 2,3-epoxysqualene to form triterpenoids or steroids [95]. In mammals, cyclization of 2,3-epoxyaqualene leads to lanosterol, which can then be converted to cholesterol [96]. Inhibition of oxidosqualene cyclase, therefore, has emerged as a viable therapeutic option to treat hypercholesterolemia and atherosclerosis $[97,98]$. 
The oxidosqualene-hopene cyclase from the thermophilic bacterium Alicyclobacillus acidocaldarius is homologous to the human enzyme and has been crystallized with OSC inhibitors [99]. Several triterpenoid ligands, most notably ocotillyl acetate, $3 \beta$-acetoxydammar-24-ene-16 $\beta, 20 R$-diol, and dammarenediol II acetate, docked well to AaOSC with docking energies of $-144.6,-139.2$, and $-138.9 \mathrm{~kJ} / \mathrm{mol}$, respectively. These dammarane triterpenoids adopt the same positions in the active site of the enzyme (Figure 14). The active site of AaOSC is a hydrophobic pocket composed of Trp489, Trp169, Phe365, Ile261, Trp312, Phe601, and Tyr420. In addition, there is a hydrogen bond formed between the $\mathrm{C}(24)-\mathrm{OH}$ of the ligand and the phenolic -OH of Tyr609. The structural similarities between triterpenoids and steroids are likely responsible for the docking properties of Boswellia triterpenoids to OSCs.

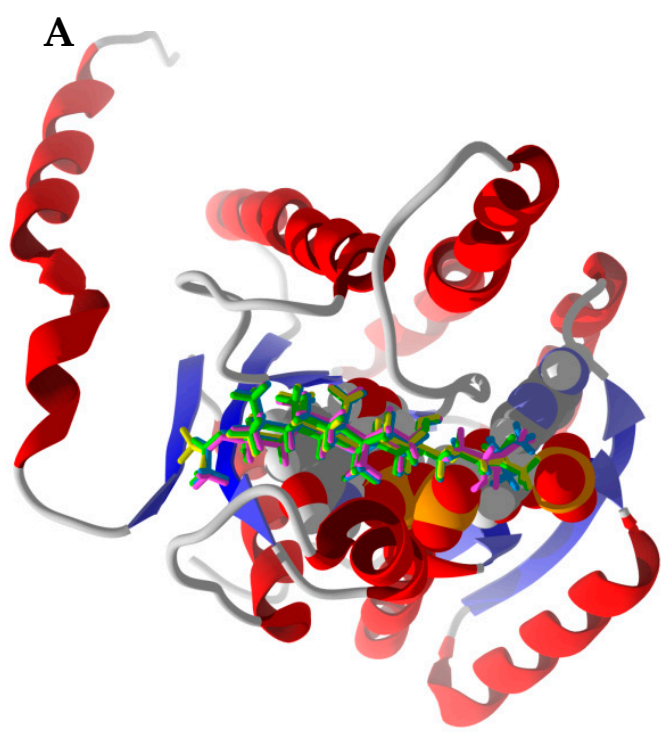

\section{B}

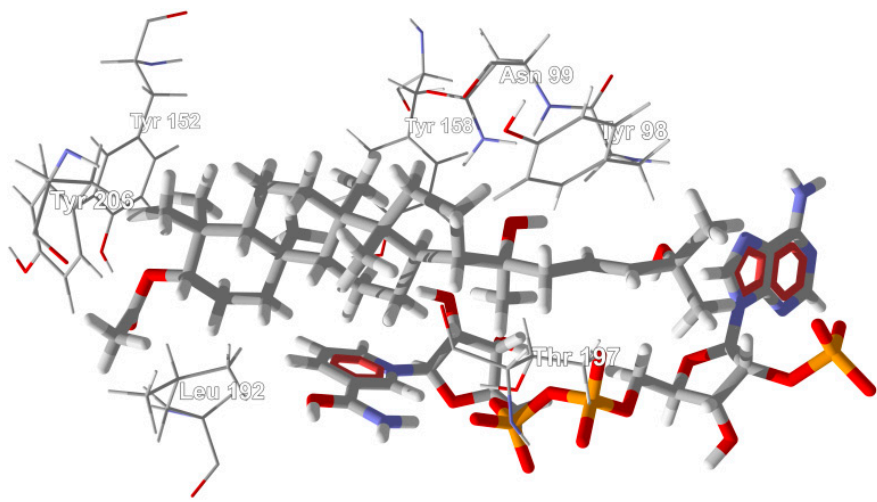

Figure 13. Guinea pig 11ß-hydroxysteroid dehydrogenase type 1 (Cp11ß-HSD, PDB 3lz6). (A): Lowest-energy docked poses of 3 $\beta$-acetoxy-20S,24R-dihydroxydammar-25-ene (magenta), $3 \beta$-acetoxydammar-24-ene-16 $\beta, 20 R$-diol (green), dammarenediol II acetate (yellow), and isofouquieryl acetate (blue) with Cp11ß-HSD. The NADPH cofactor is shown as a space-filling model. (B): Isofouqueryl acetate in the active site of Cp11 $\beta-H S D$ showing the molecular environment.

A

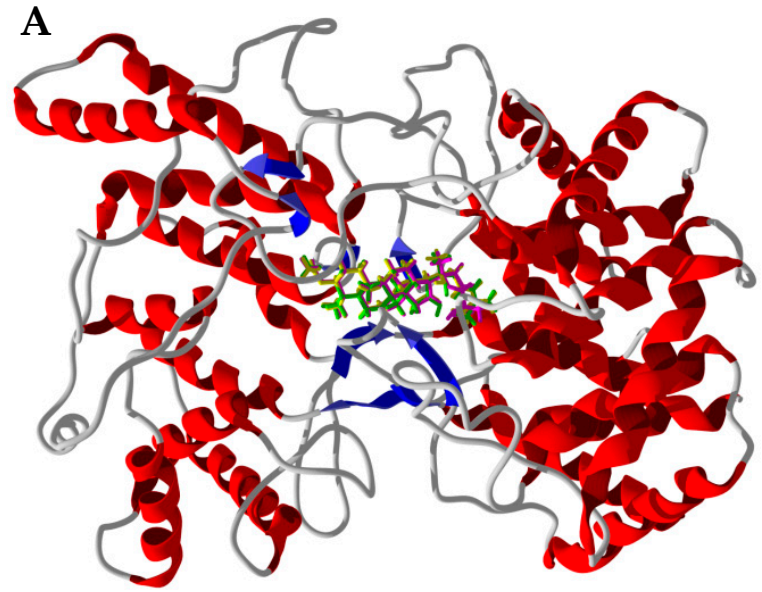

B

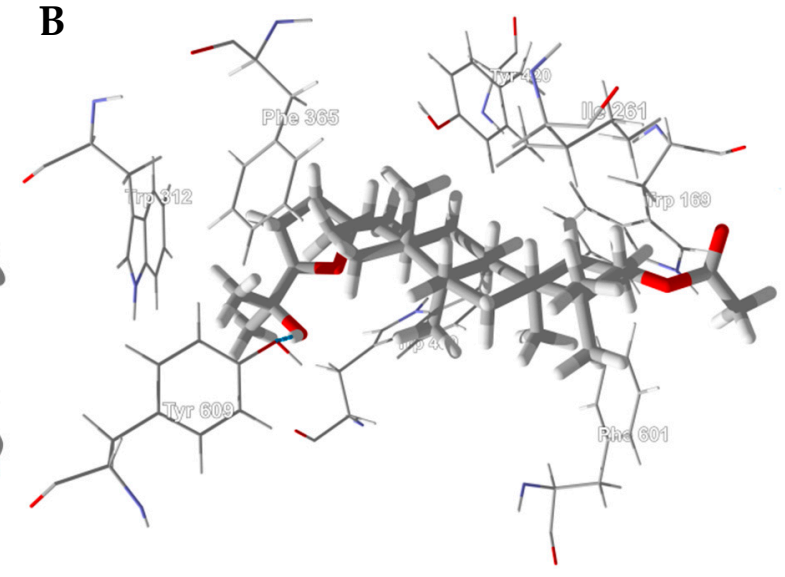

Figure 14. Alicyclobacillus acidocaldarius oxidosqualene cyclase (AaOSC, PDB 1h36). (A): Lowest energy docked poses of ocotillyl acetate (magenta), 3 $\beta$-acetoxydammar-24-ene-16 $\beta, 20 R$-diol (green), and dammarenediol II acetate (yellow) with AaOSC. (B): Molecular environment of docked ocotillyl acetate in the active site of AaOSC. 


\section{Conclusions}

Numerous Boswellia terpenoid components have shown selective docking to bacterial protein targets, antineoplastic molecular targets, diabetes-relevant targets, protein targets involved in inflammatory disease conditions, and the Alzheimer's disease target acetylcholinesterase. The molecular docking properties of Boswellia terpenoid components corroborate the traditional uses of frankincense, the clinical efficacy of frankincense, and the biological activities of Boswellia oleo-gum resins and components. Furthermore, the biomolecular targets identified in this work should lead to further exploration of development and improvement of inhibitors to treat these various disease states.

Author Contributions: K.G.B. and W.N.S. contributed equally to the computational work and manuscript preparation. Funding: This research was partially funded by dōTERRA International (Pleasant Grove, UT, USA).

Acknowledgments: This work was carried out as part of the activities of the Aromatic Plant Research Center (APRC, https:/ / aromaticplant.org/). The authors are grateful to dōTERRA International (https://www.doterra. $\mathrm{com} / \mathrm{US} / \mathrm{en}$ ) for financial support of the APRC.

Conflicts of Interest: The authors declare no conflicts of interest. The funding sponsor, dōTERRA International, played no role in the design of the study; in the collection, analysis, or interpretation of the data; conclusions of the study; or in the decision to publish the results.

\section{References}

1. Hepper, F.N. Arabian and African frankincense trees. J. Egypt. Archaeol. 1969, 55, 66-72. [CrossRef]

2. Thulin, M.; Warfa, A.M. The frankincense trees (Boswellia spp., Burseraceae) of northern Somalia and southern Arabia. Kew Bull. 1987, 42, 487-500. [CrossRef]

3. Langenheim, J.H. Plant Resins: Chemistry, Evolution, Ecology, and Ethnobotany; Timber Press, Inc.: Portland, OR, USA, 2003.

4. Gebrehiwot, K.; Muys, B.; Haile, M.; Mitloehner, R. Introducing Boswellia papyrifera (Del.) Hochst and its non-timber forest product, frankincense. Int. For. Rev. 2003, 5, 348-353. [CrossRef]

5. Murthy, T.K.; Shiva, M.P. Salai Guggul from Boswellia serrata Roxb.-its exploitation and utilisation. Indian For. 1977, 103, 466-473.

6. Moussaieff, A.; Mechoulam, R. Boswellia resin: From religious ceremonies to medical uses; a review of in-vitro, in-vivo and clinical trials. J. Pharm. Pharmacol. 2009, 61, 1281-1293. [CrossRef] [PubMed]

7. Frawley, D.; Lad, V. The Yoga of Herbs: An Ayurvedic Guide to Herbal Medicine, 2nd ed.; Lotus Press: Twin Lakes, WI, USA, 2001.

8. Mies, B.A.; Lavranos, J.J.; James, G.J. Frankincense on Soqotra island (Boswellia, Burseraceae; Yemen). Cactus Succul. J. 2000, 72, 265-278.

9. Getahon, A. Some Common Medicinal and Poisonous Plants Used in Ethiopian Folkmedicine; Addis Abeba University: Addis Abeba, Ethiopia, 1976.

10. Dannaway, F.R. Strange fires, weird smokes and psychoactive combustibles: Entheogens and incense in ancient traditions. J. Psychoact. Drugs 2010, 42, 485-497. [CrossRef] [PubMed]

11. Mertens, M.; Buettner, A.; Kirchhoff, E. The volatile constituents of frankincense-A review. Flavour Fragr. J. 2009, 24, 279-300. [CrossRef]

12. Paul, M.; Brüning, G.; Bergmann, J.; Jauch, J. A thin-layer chromatography method for the identification of three different olibanum resins (Boswellia serrata, Boswellia papyrifera and Boswellia carterii, respectively, Boswellia sacra). Phytochem. Anal. 2012, 23, 184-189. [CrossRef] [PubMed]

13. Ren, J.; Wang, Y.-G.; Wang, A.-G.; Wu, L.-Q.; Zhang, H.-J.; Wang, W.-J.; Su, Y.-L.; Qin, H.-L. Cembranoids from the gum resin of Boswellia carterii as potential antiulcerative colitis agents. J. Nat. Prod. 2015, 78, 2322-2331. [CrossRef] [PubMed]

14. Boscarelli, A.; Giglio, E.; Quagliata, C. Structure and conformation of incensole oxide. Acta Crystallogr. Sect. B 1981, 37, 744-746. [CrossRef]

15. Hamm, S.; Bleton, J.; Connan, J.; Tchapla, A. A chemical investigation by headspace SPME and GC-MS of volatile and semi-volatile terpenes in various olibanum samples. Phytochemistry 2005, 66, 1499-1514. [CrossRef] [PubMed] 
16. Forcellese, M.L.; Nicoletti, R.; Petrossi, U. The structure of isoincensole-oxide. Tetrahedron 1972, $28,325-331$. [CrossRef]

17. Li, F.; Xu, K.; Yuan, S.; Yan, D.; Liu, R.; Tan, J.; Zeng, G.; Zhou, Y.; Tan, G. Macrocyclic diterpenes from Boswellia carterii Birdwood (frankincense). Chin. J. Org. Chem. 2010, 30, 107-111. (In Chinese)

18. Basar, S.; Koch, A.; König, W.A. A verticillane-type diterpene from Boswellia carterii essential oil. Flavour Fragr. J. 2001, 16, 315-318. [CrossRef]

19. Schmidt, T.J.; Kaiser, M.; Brun, R. Complete structural assignment of serratol, a cembrane-type diterpene from Boswellia serrata, and evaluation of its antiprotozoal activity. Planta Med. 2011, 77, 849-850. [CrossRef] [PubMed]

20. Morikawa, T.; Oominami, H.; Matsuda, H.; Yoshikawa, M. New terpenoids, olibanumols D-G, from traditional Egyptian medicine olibanum, the gum-resin of Boswellia carterii. J. Nat. Med. 2011, 65, 129-134. [CrossRef] [PubMed]

21. Wang, Y.; Ren, J.; Wang, A.; Yang, J.; Ji, T.; Ma, Q.-G.; Tian, J.; Su, Y. Hepatoprotective prenylaromadendrane-type diterpenes from the gum resin of Boswellia carterii. J. Nat. Prod. 2013, 76, 2074-2079. [CrossRef] [PubMed]

22. Zhang, Y.; Ning, Z.; Lu, C.; Zhao, S.; Wang, J.; Liu, B.; Xu, X.; Liu, Y. Triterpenoid resinous metabolites from the genus Boswellia: Pharmacological activities and potential species-identifying properties. Chem. Cent. J. 2013, 7, 153. [CrossRef] [PubMed]

23. Singh, S.; Khajuria, A.; Taneja, S.C.; Johri, R.K.; Singh, J.; Qazi, G.N. Boswellic acids: A leukotriene inhibitor also effective through topical application in inflammatory disorders. Phytomedicine 2008, 15, 400-407. [CrossRef] [PubMed]

24. Banno, N.; Akihisa, T.; Yasukawa, K.; Tokuda, H.; Tabata, K.; Nakamura, Y.; Nishimura, R.; Kimura, Y.; Suzuki, T. Anti-inflammatory activities of the triterpene acids from the resin of Boswellia carteri. J. Ethnopharmacol. 2006, 107, 249-253. [CrossRef] [PubMed]

25. Yoshikawa, M.; Morikawa, T.; Oominami, H.; Matsuda, H. Absolute stereostructures of olibanumols A, B, C, H, I, and J from olibanum, gum-resin of Boswellia carterii, and inhibitors of nitric xxide production in lipopolysaccharide-activated mouse peritoneal macrophages. Chem. Pharm. Bull. 2009, 57, 957-964. [CrossRef] [PubMed]

26. Morikawa, T.; Oominami, H.; Matsuda, H.; Yoshikawa, M. Four new ursane-type triterpenes, olibanumols $\mathrm{K}, \mathrm{L}, \mathrm{M}$, and $\mathrm{N}$, from traditional Egyptian medicine olibanum, the gum-resin of Boswellia carterii. Chem. Pharm. Bull. 2010, 58, 1541-1544. [CrossRef] [PubMed]

27. Yang, J.; Ren, J.; Wang, A. Isolation, characterization, and hepatoprotective activities of terpenes from the gum resin of Boswellia carterii Birdw. Phytochem. Lett. 2018, 23, 73-77. [CrossRef]

28. Halgren, T.A. Merck Molecular Force Field. I. Basis, form, scope, parameterization, and performance of MMFF94. J. Comput. Chem. 1996, 17, 490-519. [CrossRef]

29. Zhao, Y.; Truhlar, D.G. The M06 suite of density functionals for main group thermochemistry, thermochemical kinetics, noncovalent interactions, excited states, and transition elements: Two new functionals and systematic testing of four M06-class functionals and 12 other function. Theor. Chem. Acc. 2008, 120, 215-241. [CrossRef]

30. Marenich, A.V.; Olson, R.M.; Kelly, C.P.; Cramer, C.J.; Truhlar, D.G. Self-consistent reaction field model for aqueous and nonaqueous solutions based on accurate polarized partial charges. J. Chem. Theory Comput. 2007, 3, 2011-2033. [CrossRef] [PubMed]

31. Setzer, W.N. Conformational analysis of macrocyclic frankincense (Boswellia) diterpenoids. J. Mol. Model. 2018, 24, 74. [CrossRef] [PubMed]

32. Desaphy, J.; Bret, G.; Rognan, D.; Kellenberger, E. sc-PDB: A 3D-database of ligandable binding sites. Available online: http:/ / bioinfo-pharma.u-strasbg.fr/scPDB/ (accessed on 11 September 2017).

33. Thomsen, R.; Christensen, M.H. MolDock: A new technique for high-accuracy molecular docking. J. Med. Chem. 2006, 49, 3315-3321. [CrossRef] [PubMed]

34. Setzer, M.S.; Sharifi-Rad, J.; Setzer, W.N. The search for herbal antibiotics: An in-silico investigation of antibacterial phytochemicals. Antibiotics 2016, 5, 30. [CrossRef] [PubMed]

35. Kryger, G.; Silman, I.; Sussman, J.L. Structure of acetylcholinesterase complexed with E2020 (Aricept ${ }^{\circledR}$ ): Implications for the design of new anti-Alzheimer drugs. Structure 1999, 7, 297-307. [CrossRef] 
36. Dabaghian, F.; Azadi, A.; Setooni, M.; Zarshenas, M.M. An overview on multi-ingredient memory enhancers and anti-Alzheimer's formulations from traditional Persian pharmacy. Trends Pharm. Sci. 2017, 3, 215-220.

37. Hosseinkhani, A.; Sahragard, A.; Namdari, A.; Zarshenas, M.M. Botanical sources for Alzheimer's: A review on reports from traditional Persian medicine. Am. J. Alzheimer's Dis. Other Dement. 2017, 32, 429-437. [CrossRef] [PubMed]

38. Zaker, S.R.; Beheshti, S.; Aghaie, R.; Noorbakhshnia, M. Effect of olibanum on a rat model of Alzheimer's disease induced by intracerebroventricular injection of streptozotocin. Physiol. Pharmacol. 2015, 18, 477-489.

39. Beheshti, S.; Aghaie, R. Therapeutic effect of frankincense in a rat model of Alzheimer's disease. Avicenna J. Phytomed. 2016, 6, 468-475. [PubMed]

40. Mahboubi, M.; Taghizadeh, M.; Talaei, S.A.; Firozeh, S.M.T.; Rashidi, A.A.; Tamtaji, O.R. Combined administration of Melissa officinalis and Boswellia serrata extracts in an animal model of memory. Iran. J. Psychiatry Behav. Sci. 2016, 10, e681. [CrossRef] [PubMed]

41. Tajadini, H.; Saifadini, R.; Choopani, R.; Mehrabani, M.; Kamalinejad, M.; Haghdoost, A.A. Herbal medicine Davaie Loban in mild to moderate Alzheimer's disease: A 12-week randomized double-blind placebo-controlled clinical trial. Complement. Ther. Med. 2015, 23, 767-772. [CrossRef] [PubMed]

42. Aghajani, M.; Taghizadeh, M.; Maghaminejad, F.; Rahmani, M. Effect of frankincense extract and lemon balm extract co-supplementation on memory of the elderly. Complement. Med. J. Fac. Nurs. Midwifery 2017, 7, 1968-1977.

43. Ismail, S.M.; Aluru, S.; Sambasivarao, K.R.S.; Matcha, B. Antimicrobial activity of frankincense of Boswellia serrata. Int. J. Curr. Microbiol. Appl. Sci. 2014, 3, 1095-1101.

44. Patel, N.B.; Patel, K.C. Antibacterial activity of Boswellia serrata Roxb. ex Colebr. ethanomedicinal plant against Gram negative UTI pathogens. Life Sci. Leafl. 2014, 53, 79-88.

45. El Kichaoui, A.; Abdelmoneim, A.; Elbaba, H.; El Hindi, M. The antimicrobial effects of Boswellia carterii, Glycyrrhiza glabra and Rosmarinus officinalis some pathogenic microorganisms. IUG J. Nat. Stud. 2017, 25, 208-213.

46. Michie, C.A.; Cooper, E. Frankincense and myrrh as remedies in children. J. R. Soc. Med. 1991, 84, $602-605$. [PubMed]

47. Abdallah, E.M.; Khalid, A.S.; Ibrahim, N. Antibacterial activity of oleo-gum resins of Commiphora molmol and Boswellia papyrifera against methicillin resistant Staphylococcus aureus (MRSA). Sci. Res. Essays 2009, 4, 351-356.

48. Khosravi Samani, M.; Mahmoodian, H.; Moghadamnia, A.A.; Poorsattar Bejeh Mir, A.; Chitsazan, M. The effect of frankincense in the treatment of moderate plaque-induced gingivitis: A double blinded randomized clinical trial. DARU J. Pharm. Sci. 2011, 19, 288-294.

49. Tee, W.; Lambert, J.R.; Dwyer, B. Cytotoxin production by Helicobacter pylori from patients with upper gastrointestinal-tract diseases. J. Clin. Microbiol. 1995, 33, 1203-1205. [PubMed]

50. Lemenih, M.; Teketay, D. Frankincense and myrrh resources of Ethiopia: II. Medicinal and industrial uses. Ethiop. J. Sci. 2003, 26, 161-172.

51. El-Mekkawy, S.; Meselhy, M.R.; Kusumoto, I.T.; Kadota, S.; Hattori, M.; Namba, T. Inhibitory effects of Egyptian folk medicines on human immunodeficiency virus (HIV) reverse transcriptase. Chem. Pharm. Bull. 1995, 43, 641-648. [CrossRef] [PubMed]

52. Karplus, M. Vicinal proton coupling in nuclear magnetic resonance. J. Am. Chem. Soc. 1963, 85, $2870-2871$. [CrossRef]

53. Haasnoot, C.A.G.; de Leeuw, F.A.A. M.; Altona, C. The relationship between proton-proton NMR coupling constants and substituent electronegativities-I: An empirical generalization of the Karplus equation. Tetrahedron 1980, 36, 2783-2792. [CrossRef]

54. Shen, J.; Hilgenbrink, A.R.; Xia, W.; Feng, Y.; Dimitrov, D.S.; Lockwood, M.B.; Amato, R.J.; Low, P.S. Folate receptor- $\beta$ constitutes a marker for human proinflammatory monocytes. J. Leukoc. Biol. 2014, 96, 563-570. [CrossRef] [PubMed]

55. Shen, J.; Putt, K.S.; Visscher, D.W.; Murphy, L.; Cohen, C.; Singhal, S.; Sandusky, G.; Feng, Y.; Dimitrov, D.S.; Low, P.S. Assessment of folate receptor- $\beta$ expression in human neoplastic tissues. Oncotarget 2015, 6, 14700-14709. [CrossRef] [PubMed] 
56. Wibowo, A.S.; Singh, M.; Reeder, K.M.; Carter, J.J.; Kovach, A.R.; Meng, W.; Ratnam, M.; Zhang, F.; Dann, C.E. Structures of human folate receptors reveal biological trafficking states and diversity in folate and antifolate recognition. Proc. Natl. Acad. Sci. USA 2013, 110, 15180-15188. [CrossRef] [PubMed]

57. Ernst, E. Frankincense: Systematic review. BMJ 2008, 337, a2813. [CrossRef] [PubMed]

58. Khan, M.A.; Ali, R.; Parveen, R.; Najmi, A.K.; Ahmad, S. Pharmacological evidences for cytotoxic and antitumor properties of boswellic acids from Boswellia serrata. J. Ethnopharmacol. 2016, 191, 315-323. [CrossRef] [PubMed]

59. Iram, F.; Khan, S.A.; Husain, A. Phytochemistry and potential therapeutic actions of Boswellic acids: A mini-review. Asian Pac. J. Trop. Biomed. 2017, 7, 513-523. [CrossRef]

60. Al-Yasiry, A.R.M.; Kiczorowska, B. Frankincense-Therapeutic properties. Postepy Hig. Med. Dosw. 2016, 70, 380-391. [CrossRef]

61. Popa, O.M.; Cherciu, M.; Cherciu, L.I.; Dutescu, M.I.; Bojinca, M.; Bojinca, V.; Bara, C.; Popa, L.O. ERAP1 and ERAP2 gene variations influence the risk of psoriatic arthritis in Romanian population. Arch. Immunol. Ther. Exp. 2016, 64, 123-129. [CrossRef] [PubMed]

62. Wang, H.; Syrovets, T.; Kess, D.; Büchele, B.; Hainzl, H.; Lunov, O.; Weiss, J.M.; Scharffetter-Kochanek, K.; Simmet, T. Targeting NF- $\mathrm{BB}$ with a natural triterpenoid alleviates skin inflammation in a mouse model of psoriasis. J. Immunol. 2009, 183, 4755-4763. [CrossRef] [PubMed]

63. Moustafa, F.; Feldman, S.R. A review of phosphodiesterase-inhibition and the potential role for phosphodiesterase 4-inhibitors in clinical dermatology. Dermatol. Online J. 2014, 20, 22608. [PubMed]

64. Kimmatkar, N.; Thawani, V.; Hingorani, L.; Khiyani, R. Efficacy and tolerability of Boswellia serrata extract in treatment of osteoarthritis of knee-A randomized double blind placebo controlled trial. Phytomedicine 2003, 10, 3-7. [CrossRef] [PubMed]

65. Cavaillon, J.M. Pro- versus anti-inflammatory cytokines: Myth or reality. Cell. Mol. Biol. 2001, 47, 695-702. [PubMed]

66. Bachurin, S.O.; Bovina, E.V.; Ustyugov, A.A. Drugs in clinical trials for Alzheimer's disease: The major trends. Med. Res. Rev. 2017, 37, 1186-1225. [CrossRef] [PubMed]

67. Brady, N.; Poljak, A.; Jayasena, T.; Sachdev, P. Natural plant-derived acetylcholinesterase inhibitors: Relevance for Alzheimer's disease. In Natural Products Targeting Clinically Relelvant Enzymes; Andrade, P.B., Valentão, P., Pereira, D.M., Eds.; Wiley-VCH: Weinheim, Germany, 2017; pp. 297-318.

68. Bürkle, A.; Brabeck, C.; Diefenbach, J.; Beneke, S. The emerging role of poly(ADP-ribose) polymerase-1 in longevity. Int. J. Biochem. Cell Biol. 2005, 37, 1043-1053. [CrossRef] [PubMed]

69. Bryant, H.E.; Schultz, N.; Thomas, H.D.; Parker, K.M.; Flower, D.; Lopez, E.; Kyle, S.; Meuth, M.; Curtin, N.J.; Helleday, T. Specific killing of BRCA2-deficient tumours with inhibitors of poly(ADP-ribose) polymerase. Nature 2007, 434, 913-917. [CrossRef] [PubMed]

70. Ratnam, K.; Low, J.A. Current development of clinical inhibitors of poly(ADP-ribose) polymerase in oncology. Clin. Cancer Res. 2007, 13, 1383-1388. [CrossRef] [PubMed]

71. Xia, W.; Low, P.S. Folate-targeted therapies for cancer. J. Med. Chem. 2010, 53, 6811-6824. [CrossRef] [PubMed]

72. Low, P.S.; Henne, W.A.; Doorneweerd, D.D. Discovery and development of folic-acid-based receptor targeting for imaging and therapy of cancer and inflammatory diseases. Acc. Chem. Res. 2008, 41, 120-129. [CrossRef] [PubMed]

73. Miller, T.A.; Witter, D.J.; Belvedere, S. Histone deacetylase inhibitors. J. Med. Chem. 2003, 46, 5097-5116. [CrossRef] [PubMed]

74. Mottamal, M.; Zheng, S.; Huang, T.L.; Wang, G. Histone deacetylase inhibitors in clinical studies as templates for new anticancer agents. Molecules 2015, 20, 3898-3941. [CrossRef] [PubMed]

75. Yoshida, M.; Furumai, R.; Nishiyama, M.; Komatsu, Y.; Nishino, N.; Horinouchi, S. Histone deacetylase as a new target for cancer chemotherapy. Cancer Chemother. Pharmacol. 2001, 48, S20-S26. [CrossRef] [PubMed]

76. Lane, A.A.; Chabner, B.A. Histone deacetylase inhibitors in cancer therapy. J. Clin. Oncol. 2009, 27, 5459-5468. [CrossRef] [PubMed]

77. Karpozilos, A.; Pavlidis, N. The treatment of cancer in Greek antiquity. Eur. J. Cancer 2004, 40, $2033-2040$. [CrossRef] [PubMed] 
78. Hamidpour, R.; Hamidpour, S.; Hamidpour, M.; Shahlari, M. Frankincense (乳香 Rǔ Xiāng; Boswellia species): From the selection of traditional applications to the novel phytotherapy for the prevention and treatment of serious diseases. J. Tradit. Complement. Med. 2013, 3, 221-226. [CrossRef] [PubMed]

79. Frank, M.B.; Yang, Q.; Osban, J.; Azzarello, J.T.; Saban, M.R.; Saban, R.; Ashley, R.A.; Welter, J.C.; Fung, K.M.; Lin, H.K. Frankincense oil derived from Boswellia carteri induces tumor cell specific cytotoxicity. BMC Complement. Altern. Med. 2009, 9, 6. [CrossRef] [PubMed]

80. Forouzandeh, S.; Naghsh, N.; Salimi, S.; Jahantigh, D. Cytotoxic effect of Boswellia serrata hydroalcoholic extract on human cervical carcinoma epithelial cell line. Med. Lab. J. 2014, 8, 7-13.

81. Hakkim, F.L.; Al-Buloshi, M.; Al-Sabahi, J. Frankincense derived heavy terpene cocktail boosting breast cancer cell (MDA-MB-231) death in vitro. Asian Pac. J. Trop. Biomed. 2015, 5, 824-828. [CrossRef]

82. Eichhorn, T.; Greten, H.J.; Efferth, T. Molecular determinants of the response of tumor cells to boswellic acids. Pharmaceuticals 2011, 4, 1171-1182. [CrossRef]

83. Agrawal, S.S.; Saraswati, S.; Mathur, R.; Pandey, M. Antitumor properties of Boswellic acid against Ehrlich ascites cells bearing mouse. Food Chem. Toxicol. 2011, 49, 1924-1934. [CrossRef] [PubMed]

84. Takahashi, M.; Sung, B.; Shen, Y.; Hur, K.; Link, A.; Boland, C.R.; Aggarwal, B.B.; Goel, A. Boswellic acid exerts antitumor effects in colorectal cancer cells by modulating expression of the let-7 and miR-200 microRNA family. Carcinogenesis 2012, 33, 2441-2449. [CrossRef] [PubMed]

85. Yadav, V.R.; Prasad, S.; Sung, B.; Kannappan, R.; Aggarwal, B.B. Targeting inflammatory pathways by triterpenoids for prevention and treatment of cancer. Toxins 2010, 2, 2428-2466. [CrossRef] [PubMed]

86. Ranzato, E.; Martinotti, S.; Volante, A.; Tava, A.; Masini, M.A.; Burlando, B. The major Boswellia serrata active 3 -acetyl-11-keto- $\beta$-boswellic acid strengthens interleukin- $1 \alpha$ upregulation of matrix metalloproteinase- 9 via JNK MAP kinase activation. Phytomedicine 2017, 36, 176-182. [CrossRef] [PubMed]

87. Seckl, J.R.; Walker, B.R. Minireview: $11 \beta$-Hydroxysteroid dehydrogenase type $1-$ A tissue-specific amplifier of glucocorticoid action. Endocrinology 2001, 142, 1371-1376. [CrossRef] [PubMed]

88. Morton, N.M.; Paterson, J.M.; Masuzaki, H.; Holmes, M.C.; Staels, B.; Fievet, C.; Walker, B.R.; Flier, J.S.; Mullins, J.J.; Seckl, J.R. Novel adipose tissue-mediated resistance to diet-induced visceral obesity in 11ß-hydroxysteroid dehydrogenase type 1-deficient mice. Diabetes 2004, 53, 931-938. [CrossRef] [PubMed]

89. Hosfield, D.J.; Wu, Y.; Skene, E.J.; Hilgers, M.; Jennings, A.; Snell, G.P.; Aertgeerts, K. Conformational flexibility in crystal structures of human $11 \beta$-hydroxysteroid dehydrogenase type I provide insights into glucocorticoid interconversion and enzyme regulation. J. Biol. Chem. 2005, 280, 4639-4648. [CrossRef] [PubMed]

90. Wan, Z.K.; Chenail, E.; Xiang, J.; Li, H.Q.; Ipek, M.; Bard, J.; Svenson, K.; Mansour, T.S.; Xu, X.; Tian, X.; et al. Efficacious $11 \beta$-hydroxysteroid dehydrogenase type I inhibitors in the diet-induced obesity mouse model. J. Med. Chem. 2009, 52, 5449-5461. [CrossRef] [PubMed]

91. Ahangarpour, A.; Heidari, H.; Fatemeh, R.A.A.; Pakmehr, M.; Shahbazian, H.; Ahmadi, I.; Mombeini, Z.; Mehrangiz, B.H. Effect of Boswellia serrata supplementation on blood lipid, hepatic enzymes and fructosamine levels in type2 diabetic patients. J. Diabetes Metab. Disord. 2014, 13, 29. [CrossRef] [PubMed]

92. Khalili, N.; Fereydoonzadeh, R.; Mohtashami, R.; Mehrzadi, S.; Heydari, M.; Huseini, H.F. Silymarin, olibanum, and nettle, a mixed herbal formulation in the treatment of type II diabetes: A randomized, double-blind, placebo-controlled, clinical trial. J. Evid. Based Complement. Altern. Med. 2017, 22, 603-608. [CrossRef] [PubMed]

93. Shehata, A.M.; Quintanilla-Fend, L.; Bettio, S.; Singh, C.B.; Ammon, H.P.T. Prevention of multiple low-dose streptozotocin (MLD-STZ) diabetes in mice by an extract from gum resin of Boswellia serrata (BE). Phytomedicine 2011, 18, 1037-1044. [CrossRef] [PubMed]

94. Kavitha, J.V.; Rosario, J.F.; Chandran, J.; Anbu, P.; Bakkiyanathan. Hypoglycemic and other related effects of Boswellia glabra in alloxan-induced diabetic rats. Indian J. Physiol. Pharmacol. 2007, 51, 29-39. [PubMed]

95. Abe, I.; Rohmer, M.; Prestwich, G.D. Enzymatic cyclization of squalene and oxidosqualene to sterols and triterpenes. Chem. Rev. 1993, 93, 2189-2206. [CrossRef]

96. Nes, W.D. Biosynthesis of cholesterol and other sterols. Chem. Rev. 2011, 111, 6423-6451. [CrossRef] [PubMed]

97. Huff, M.W.; Telford, D.E. Lord of the rings-The mechanism for oxidosqualene:lanosterol cyclase becomes crystal clear. Trends Pharmacol. Sci. 2005, 26, 335-340. [CrossRef] [PubMed] 
98. Rabelo, V.W.H.; Romeiro, N.C.; Abreu, P.A. Design strategies of oxidosqualene cyclase inhibitors: Targeting the sterol biosynthetic pathway. J. Steroid Biochem. Mol. Biol. 2017, 171, 305-317. [CrossRef] [PubMed]

99. Lenhart, A.; Reinert, D.J.; Aebi, J.D.; Dehmlow, H.; Morand, O.H.; Schulz, G.E. Binding structures and potencies of oxidosqualene cyclase inhibitors with the homologous squalene-hopene cyclase. J. Med. Chem. 2003, 46, 2083-2092. [CrossRef] [PubMed] 